\title{
تماثيل الثعبان في مصر القديمة وشرق شبة الجزيرة العربية (دراسة مقارنة)
}

\section{د/سمر حماد فهيم}

مقدمة: الشرق الأدنى القديم فقد ارتبطت نشأة المحتمعات وتاريخها ارتباطاً وثيقاً بعوامل البيئة الجغرافية فديانة أي بي بإي شعب تتأثر بطبيعة البلاد التي يسكنها، ومن هنا فقد لعبت العديد من الحيوانات دورا هاماً في التقديس وكان من أبرزها الثعبان الذي نال أهمية كبيرة في عدد غير قليل من الحضارات القديمة منها مصر القديمة وحضارة بلاد النهرين وحضارة بلاد اليونان وشبة الجزيرة العربية، فالثعبان من الحيوانات التي قُدست منذ فئل أقدم العصور في جميع الحضارات القديمة ولا تزال بعض الشعوب تقدس الثعبان، فتعددت مظاهر عبادة

الثعبان على مدي العصور وتمثلت في أكثر من معبود، فضلا عن ارتباط الثعبان بكثير من الآلهة. (1) لم يكن لتماثيل الثعابين مساحة كافية للنقاث في البحوث المتعلقة بأثار حضارتي دلمون وبحان، فيحاول هذا البحث المقارنة بين تماثيل الثعبان في المنطقتين وتحميع بعض الدلائل والمكتشفات ومناقشتها وتحليلها، والوصول الى ان كان هناك دلائل اثرية تشير الى أهمية الثعبان وتماثيله في المنطقتين وربما تصل أهميته المى العبادة والتقديس في كلاً من مصر القديمة، وشرق شبة الجزيرة العربية وهذا بناء على الدلائل الاثرية خلال تلك الفترة وتنوعها، ولكن تلك الدلائل ربما تعطى بعض المؤشرات لاهتمام السكان بالثعابين وقد تكون انتقلت من مناطق بجاورة. تبوأ الثعبان مكانه كبيره في حياه سكان منطقه الشرق الادلى القديم وشبة الجزيرة العربية دل على ذلك

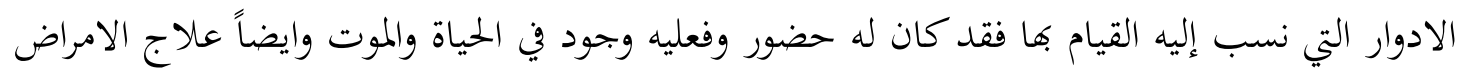
وطرد الشرور وجلبها وكذلك ما يتعلق بالنسل والخصوبة فمنذ زمن بعيد ارتبط الثعبان بالملك والمعبودات، فقد جمع ما بين كونه حارساً وفي الوقت نفسه يمثل الشر فهو يعتبر احدى القوي التي يمكن من خلالها هلاك الأعداء (r) فتمتعت الثعابين بالكثير من صفات التي جعلت منها رمزاً للخصوبة والتجديد والاستمرارية والحماية وأيضا مصدرا للخوف لما لها من تأثير على البشر والحيوانات. (r)

(') نادية يحي شحاتة عبد الحفيظ، 11 • r: عبادة الثعبان وتصويةة في الفن اليوناني، رسالة ماجستير غير منشورة، كلية الآداب، جامعة المنيا، ص أ.

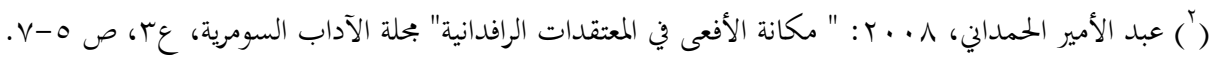

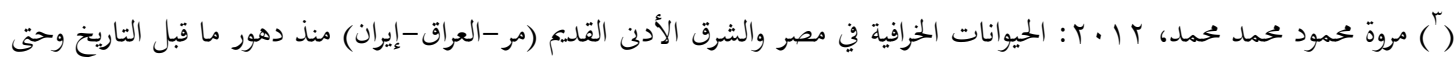

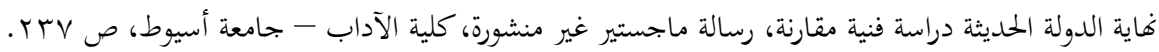


ظهر الثعبان كقوى مقدسة منذ عصور ما قبل التاريخ على الكثير من النقوش الصخرية ورسومات الفخار والصلايات وغيرها، (๕) كما شُكلت به بعض أدوات الحلى ومن هنا ذُكر الثعبان في الأساطير فئرئ

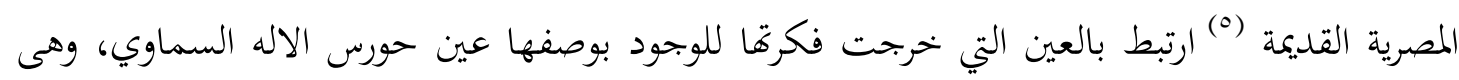
عين ثالثة بالإضافة لعيني الإله وتمثل ثعبان الصل المثبت في التاج أو عصابة الرأس على جبين الملك، وبجانب الأسطورة فإن المصري القديم سجل علاقته بالثعبان منقوشاً على لوحات صحن الكحل وجدران المقابر لاعتقاده الراسخ بأن للعالم السفلى بوابات كثيرة تقوم بحراستها الثعابين فتخيلها اها حارسة على له كل شيء في العالم الآخر وفن العديد من الاماكن كما في العشب والحقول والرمال والأحجار واماكن

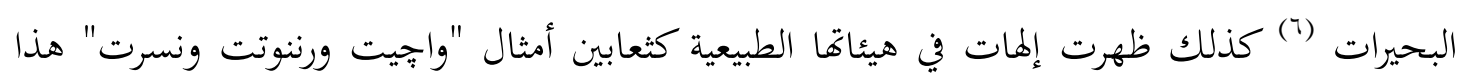

بالإضافة الى البرديات الأدبية التي كان للثعبان دور فيها. الثعابين وارتباطها بالأساطير والمعتقدات لم تكن لها مساحه كافيه من خلال البحوث والدراسات في منطقه شرق الجزيرة العربية، فهناك معلومات قليله عن الثعبان ورمزيته في تلك المنطقة، فكان هناك وجود للثعبان شرق الجزيرة العربية خلال عصور ما قبل التاريخ وهناك بعض الباحثين الذين تطرقوا الى هذا الموضوع وتم اثبات وجود الثعبان من خلال المقتنيات الأثرية التي تم العثور عليها، او من خلال الهياكل العظمية وبقايا الثعابين ولكن لم يكن هناك دليل قاطع على وجود عباده للثعابين في بعض الحضارات في منطقه شرق الجزيرة العربية بعكس وجود هذه العبادة في حضارات اخري كما في حضارة مصر القديمة.

الثعبان كلمة مشتق من اللاتينية Serpens حيث تستخدم في الديانة للدلالة على الثعبان او شبيه له،

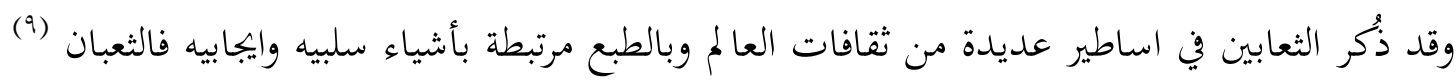

Mertens, 1960: The World of Amphibians and Reptiles, (Trans. By Parker), London, p. 28.

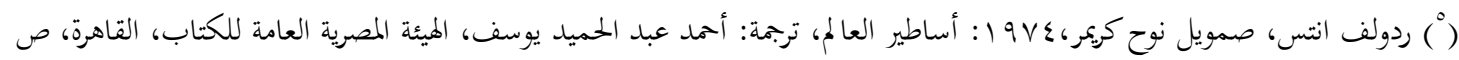

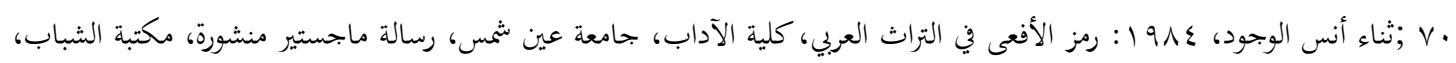

( ) De Buck, C., T., 1948: VII, 304 (sp. 1052), pp. 1-10.

( ) كما في قصة الملاح الغريق ولمزيد من المعلومات انظر:

Blackman, A., M., 1932: Middle-Egyptian Stories -- Part I. Fondation Égyptologique Reine Élisabeth، Brussels.

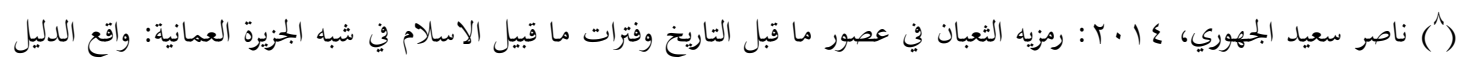

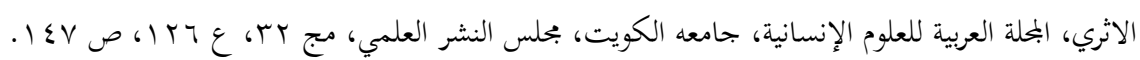

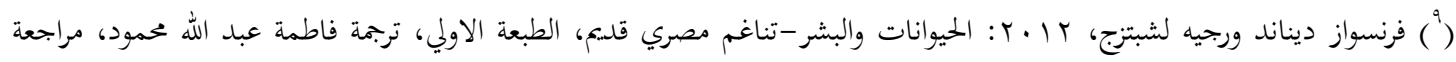

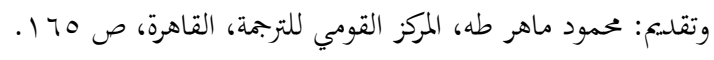


يعتبر واحد من أقدم وأكثر الرموز الأسطورية انتشاراً، فحوله دارت العديد من الاساطير فلا يوجد حيوان

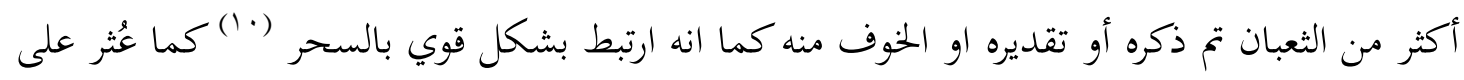
الثعبان في العديد من الحضارات القديمة ويمكن القول ان ذُكر الثعبان في كثير من الثقافات القديمة مرجعه السم المتواجد في الثعبان، فقد عثر على الثعبان في معظم ثقافات وحضارات العالم بالإضافة الم ذكره في العديد من الاساطير القديمة مقروناً بالعبادة والحب والصحة والمرض والشفاء والخلود والموت والتجديد والحيوية والبعث، فكان ينظر الى الثعبان في بعض الاحيان على انه رمز الخوف والشر. (11)

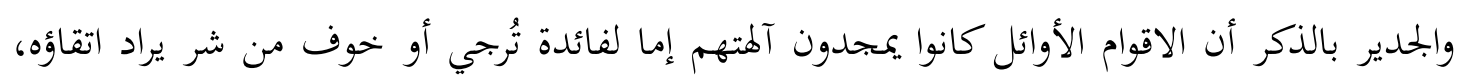
ومن ثم تأتي قدسية الثعبان فكان يُعيد اتقاء لدغته المميته، فقدسية الثعبان جاءت من مراقبة الإنسان للطبيعة، كما أن الثعبان كان الأكثر سحراً، فقدرته على تحديد جلده تبدو بالنسبة للناظر إليه وكأهنا ولادة جديدة، لذا فقد غدت رمزاً للانبعاث والخلود، كما ارتبط بالولادة والأمهات، وهي رمز القوة بسبب حركاتها التي تمكنها من أن تلف على غريمها لتقتلها، وبسبب سمها وشرها فهي ترمز إلى جانب الطبيعة الشرير. فقدرقا على القتل وعلى الشفاء معاً، جعلتها عبر التاريخ رمزاً للقوى الإيجابية والسلبية

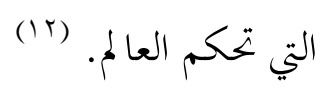

لذا فإن صورة الثعبان تستحضر على نهو سحري كلا من الحياة والموت بالإضافة إلى قوى الانبعاث والخصب، حيث ظهرت الدلائل الأثرية المصور عليها الثعبان في فترة ما قبل التاريخ من الالف الثالث قبل الميلاد حتى اوائل القرن الميلادي ولكن من الملاحظ أنه عُثر على العديد من الأدلة الاثرية التي صور عليها الثعبان والتي ترجع الى الألف الأول ق.م في شرق الجزيرة العربية. (rا)

عبر الثعبان عن رمز معنوي للحياة، كما يعتقد أنه يحرس منابع المياه فيما قبل التاريخ وأنه يقوم بتجديد

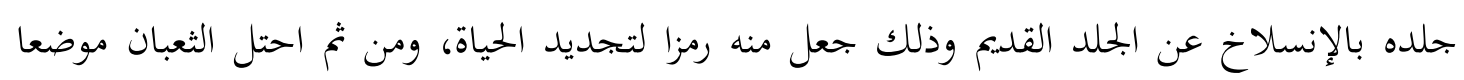

$\left({ }^{10}\right)$ Okuda, J., \& Kiyokawa, R., 2000: "Snake as a symbol in medicine and pharmacy-a historical study", yakushigaku zasshi: the journal of Japanese history of pharmacy, Japanese society of history of pharmacy, Japan, 35.1, p. 25-40. 
هاما في الديانة المصرية والسحر وكان يرمز الى القوة الملكية التي لا تقهر وكذلك ارتبط أحيانا ببعض آلمة

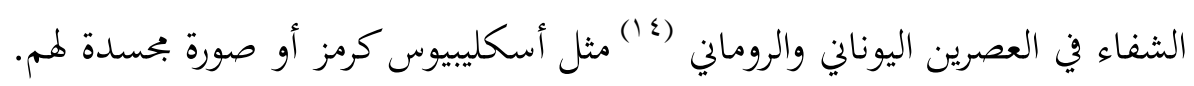
من خلال ما سبق كان من الضروري توضيح المكانة التي تمتع بها الثعبان في منطقتي شرق شبة الجزيرة العربية ومصر القديمة، وإبراز النتائج التي تم التوصل إليها من خلال الدراسات، والتي كان لها تأثيرات إيجابية في توضيح الأساليب الفنية وتحليل القطع الاثرية بدقة.

بادئ ذي بلدً: الثعبان في الحضارات القديمة: الدراسة، بما في ذلك شبه الجزيرة العربية وبلاد فارس وبلاد النهرين واليونان، ففي جنوب الجزيرة العربية ارتبط اسم الثعبان بالاسم القومي مينان "Winaean" للإله واد "Wadd" (10) يقترح انه ربما تم التضحية بالثعبان للإله واد، كما ان انواع مختلف من الثعابين كانت تطلق كأسماء شخصيه للأنثى في اللهجات السبئية والبقتبانية والحضرمية، ولكنه يطلق كاسم شخصي للذكور في اللهجات العربية الثمالية كاللحيانية والصفوية والثمودية. كما تم تفسير تصاوير الثعابين على المعدن في جنوب الجزيرة العربية كقرابين. (17) (1) (1)

ظهر الثعبان في الاساطير اليونانية بشكل كبير، فقد قام اليونانيون بالتفرقة بين كلمة Snake الثعبان و Serpent Asklepios

$\left({ }^{14}\right)$ Hussein Abdel-Aziz, 1996: The Anthropomorphic Anguipede deities in Graeco Roman Egypt , p. 1-2.

(") الاله واد: أحد الآلة التي تم عبادقام في الجزيرة العربية وكان يرمز للقمر، وكان من الآلمة المحبة لدى العرب قديماً ولمزيد من المعلومات

J. Ryckmans, J, 1987: "The Old South Arabian Religion", in W. Daum (Ed.), Yemen: 3000 Years Of Art And Civilization In Arabia Felix.

$\left.{ }^{16}\right)$ Potts, D., T., 2007: Revisiting the snake burials of the Late Dilmun building complex on Bahrain, Arabian Archaeology and Epigraphy, P. 55-74.

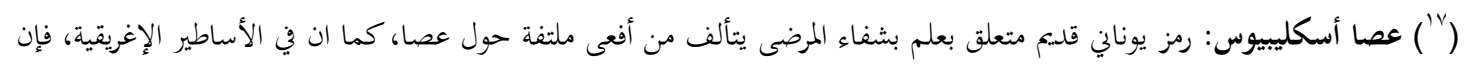

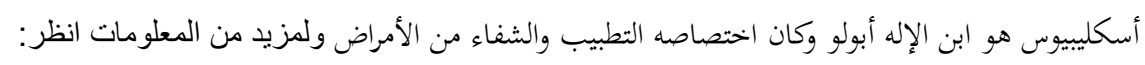
Albert, R., Jonsen, 1990: The New Medicine and the Old Ethics, Harvard University Press. 
الثعبان رمز لإله الطب عند اليونانيين اسكليبيوس، وهو ينحدر من عائلة تعاطت الطب في زمنهم، وجده هو الإله 》أبولوش)، وهو أيضاً من آلهة الطب، وزوجته أو ابنته على الخلاف بين مؤرخيهم هي إلهة الصحة واسمها (هيجيا) ويقال إن شيرون علمّت اسكليبيوس أسرار الطب بالأعشاب، وتعاطي هذه المهنة حتى تفوق فيها. هكذا تذكر الأسطورة، ومن ثم كانت الثعابين عندهم رمزاً للحياة والحكمة والشفاء وقد بقي الثعبان الملتف حول العصا رمز للصيدلة حتى اليوم. (9) فئن

الثعبان عند اليونان لعب العديد من الأدوار في المعتقدات الدينية اليونانية لعل أشهر هذه الادوار هو أن شعر الميدوزا (·r) تنتهى خصلاته بهيئة ثعابين سامة كما صيغت حوله العديد من الأساطير، ولعب أيضا دورا جنائزيا حيث بجده مصور على العديد من شواهد القبور ليدفع الشر عن المقبرة. (YI) وفي جزيرة كريت تم تقديس الثعبان منذ العصر المينوى وكان مرتبطا بعبادة الإلمة الأم التي مثلت رمز الحماية والخصوبة، وقد عثر على العديد من التماثيل النسائية التي تصور المرأة والثعبان معاً، واستمرت عبادة الثعبان في العصور اللاحقة وارتبطت بعبادة إلهة الحماية أثينا، وارتبط بعبادة إلهة الخصوبة ديميتر، وإلهة الصحة هيجيا.

وفي الغالب الأعم يتضح أيضا أن الثعبان ارتبط بعقيدة وفكر اليوناني القديم من خلال صفتين أتصف كمما الثعبان طبقا لطبيعته وسلوكياته وهما النفع والضرر وتلخصت النفع في رمزية الشفاء حيث عولج بعض أصابات المرضى من خلال لعق الثعبان للجزء المصاب وارتباطه بآلة الشفاء أسكليبيوس وهيجيا. الحماية سواء حماية الآلمة ومتلكاتهم فكان الثعبان حاميا لمملكة هاديس متمثل في كربيروس، وكان حاميا

$\left({ }^{18}\right)$ Parpola, S., 2007: Assyrian- English -Assyrian Dictionary, University of Helsinki, p.68, 104 .

( ) الموقع الرسمي لجريدة البيان الاماراتية

https://www.albayan.ae/paths/books/2009-03-01-1.410235

( (ب) الميدوزا: بناء على الاساطير اليونانية هي إحدى الغورغونات الثلاث، اللواتي يحولن كل من يقع نظرهن عليه إلى حجر. كانت

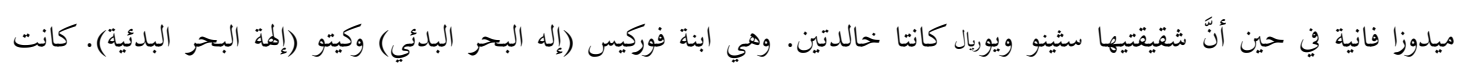

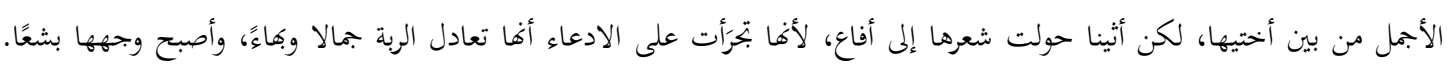

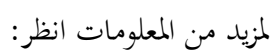

Wilk, Stephen R. (2007). Medusa: Solving the Mystery of the Gorgon. Oxford University Press.

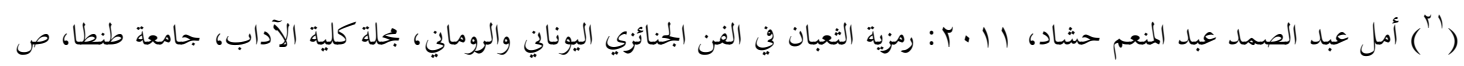


لشجرة الهسبيريديس التى أهدقا الإلمة جايا لهيرا، وكما كان الثعبان حاميا للمدن والمحارب والمنازل متمثل في زيوس كتيسيوس وميليخيوس. أما صفة الضرر فعبر عنها بمهاجمة الثعبان للآلهة. ظهر الثعبان في شكلين الأول كائن خرافى بجسم كبير هاجم كبير الآلهة زيوس وشكل خطرا" على الآلمة والبشر وسمى التيفون والثانية في شكل ثعبان كبير هاجم ليتو وأبنائها أبوللو وأرتميس وعرف بانسم البيثون، كما صور الثعبان بكثرة على جميع أنواع الفنون الإغريقية، وصور الثعبان في الأعمال النحتية سواء كانت تماثيل نحتية مثل تلك الخاصة بأسكليبيوس وهيجيا أو اللوحات مثل التي تصور زيوس كتيسيوس وزيوس ميليخيوس وتصويره على شواهد القبور والتي يرمز فيها الثعبان إلى روح المتوف،،

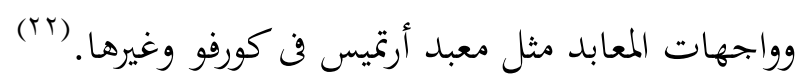

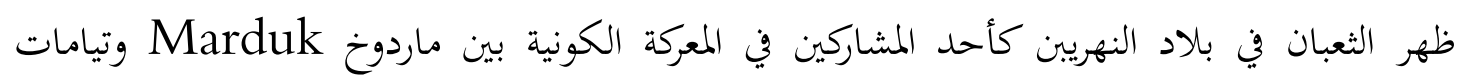
فكان ترويض الثعبان هو مفتاح السلطة والسيطرة والحكم المقدس كذلك ورد الثعبان وهو

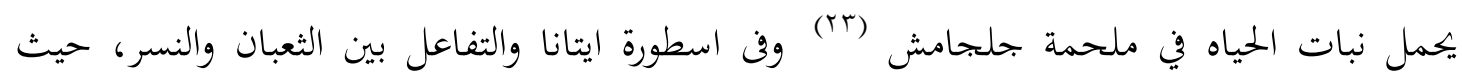
يؤدي الأخير دور الشر والثعبان يؤدي دور الضحية هذا بالإضافة الى استخدام سكان بلاد النهرين

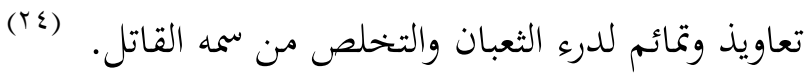
استخدم الثعبان في بلاد النهرين كدلالة على وجود العلاقة الرمزية وبصفة خاصة مع المعبود "نينجيشزيدا Nindishzida

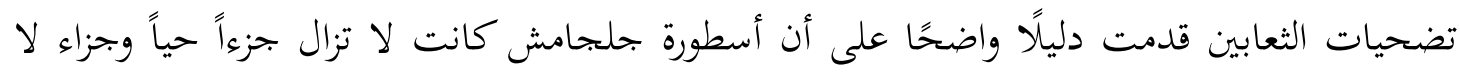

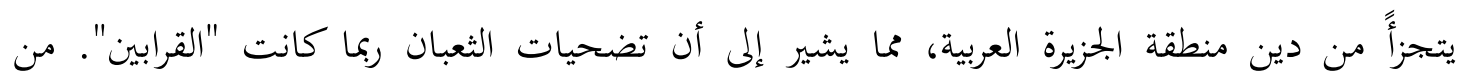

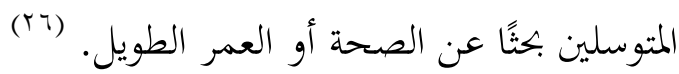

$$
\text { (T) }
$$

(23) Hansman, J., 1976: "Gilgamesh,Humbaba and the Land of the Erin-Trees", Iraq 38,No.1, p.23-35.

$\left(^{24}\right)$ Wilson , L., S., \& Nachash, and Asherah, 1999: Serpent Symbolism and Death ,Life, and Healing In The Ancient Near East ,Ph.D.,Yale University ,p.12-17.

( ) المعبود نينجيشزيدا هو الثعبان المعبود والحارس الشخصي والحامي للملك جوديا Gudea حاكم مدينة لحش، حيث كان يمثل

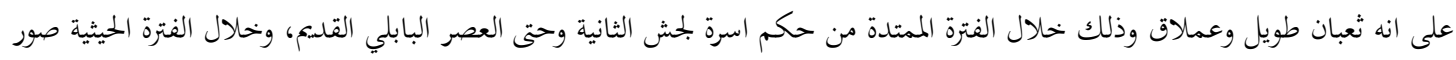

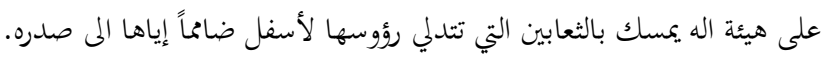

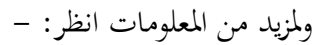

Frothingham, A., L., 1916: "Babylonian Origin of Hermes the Snake-God, and of the Caduceus1",AJA 20,No.2, p.181-82.

$\left(^{26}\right)$ Bibby, T., G., 1969: Looking for Dilmun. New York: Alfred Knopf, p. 165. 
لعبت الثعابين في حضارة عيلام (rV) دورًا مهمًا في فن ورسم الأيقونات. الغالبية العظمى من هذه تظهر على الأختام الأسطوانية والتماثيل التي ترجع الى الألفية الثانية قبل الميالد من سوسة، في خوزستان، بصرف النظر عن استخدامها كزخارف قائمة بذاهما على الأختام او نقوش على الصخور، فإن الثعبان شارك العديد من الآلهه فقد جاء احياناً عبارة عن جسم ملتف، والجزء العلوي منه ينبثق وغالبًا ما يظهر إما مع وجه بجسم، يتجه في الاتحاه المعاكس لذلك الذي يظهر فيه الإله مواجهاً، أو يتم الإمساك به من قبل إله ذكر علاوة على ذلك. (َ)

نظرا لأهمية شبة الجزيرة العُمانية للفرس فقد قاموا بالسيطرة عليها خلال الألف الأول قبل الميلاد من خلال الدولة العيلامية والاخمينيون قبل السيطرة على بابل فقد سيطروا على بعض مراكز الجزيرة العربية (Y9) وبجانب بعض السمات الفارسية التي وجدات في بعض القطع واللقى الأثرية داخل شبة الجزيرة العُمانية، حيث عثر على بعض الفخاريات التي تحمل بعض سمات الفن الفارسي فضلا عن استخدام الثعابين في مواقع عديدة داخل بحان وأيضا داخل بلاد فارس (•+") كما أثرت الزخارف والرسومات الموجودة على الأحجار والفخار في إيران وبلاد فارس داخل بحان وظهر ذلك في العديد من الجرار و السلطانيات. (rان

(TV) والجنوب الغربي من إيران، بالإضافة إلى جزء صغير جنوب العراق. وكانت عيلام من بين القارئ القوى السياسية الرائدة في الشرق الأدن القديم. ولمزيد من المعلومات انظر: Elizabeth, Carter, \& Matthew, W., Stolper, 1984: Elam: surveys of political history and archaeology University of California Press.

$\left(^{28}\right)$ Potts, D., T., 2004: The numinious and the immanent: Some thoughts on Kurangun and the Rudkhaneh-e Fahliyan. In: von Folsach K Thrane H \& Thuesen T، eds. From handaxe to khan: Essays presented to Peder Mortensen on the occasion of his 70th birthday. Aarhus: Aarhus University Press: 153.

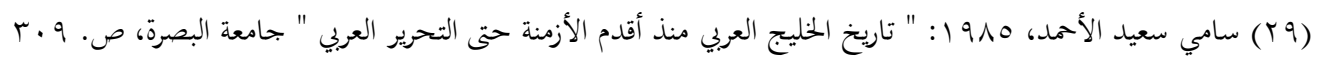
(30) Lombard , P., 1989: “The Late Dilmun period ( 1000 - 400 B.C. ) “BNM , Vol. 1 , p.56.

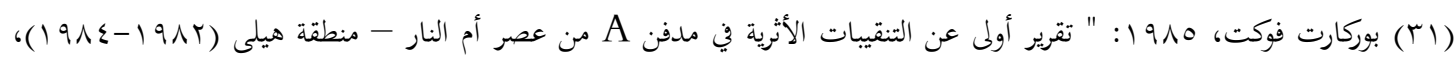

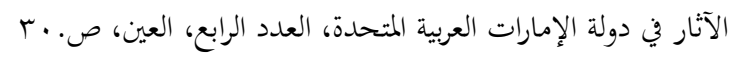




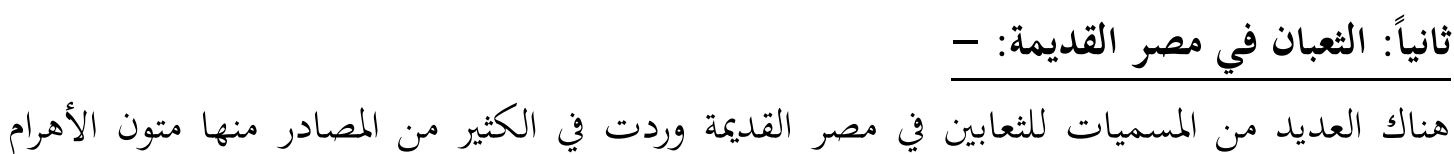
ومتون التوابيت كتاب الموتى وتم تقسم الثعابين الى ثلاث بحموعات رئيسية وهي الثعابين النافعة والثعابين

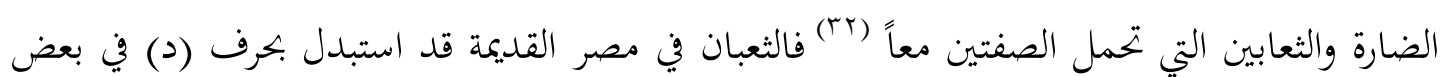

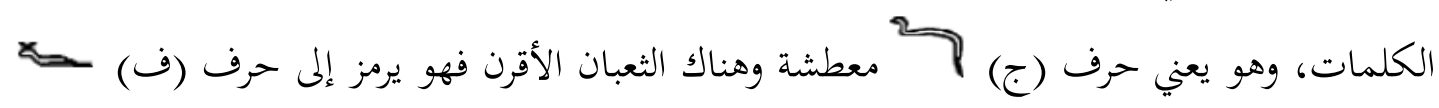

لعبت الثعابين كزواحف مقدسة دوراً هاماً منذ ما قبل التاريخ عند المصري القديم ومنذ بداية الاسرات ارتبطت الحية بإلهات بعينها مثل واجيت ربة الشمال وونوت إلهة الآثمونيين ونسرت والمعبودتين حنوت وامتت اللتين ارتبطتا بأبناء الملك إبان العصر العتيق، حيث ظهرتا معهم على الاختام (عَ) فتقديس الثعبان في مصر القديمة تم بشكل كبير ليس لشكلة وانما لقدره الكبير في بعث الطاقة المتجددة فالكوبرا كانت موجودة بشكل ثابت كجزء من غطاء رأس الملك واعتقد المصريين القدماء ان الثعبان الحامى والحارس لرمز الملكية هذا بالإضافة إلى استخدام الثعبان في السحر للتخلص من التأثيرات الضارة. (ro) قُسم الثعبان في مصر القديمة إلى عائلات متعددة فشملت منها ثعبان "الباح" وهو ثعبان غير سام وظهر

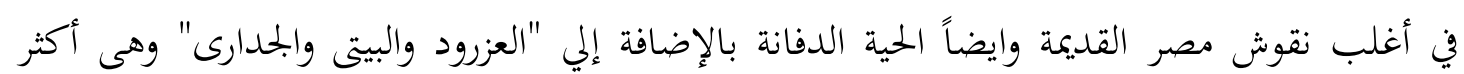
الأنواع إنتشاراً في البيئة المصرية، ولكن أشهر تلك الثعابين هي ثعبان الكوبرا، ويعتبر ثعبان الكوبرا من أكثر الثعابين ظهوراً في النقوش المصرية القديمة وظل مقدساً ووضع في أرفع مكانة في التاريخ المصري

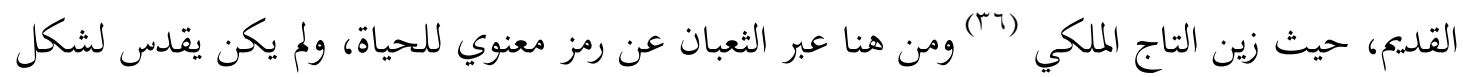
جسمه وانما للطاقة المنبعثة من هذا الكائن الملتف الملتوى والذى تخطى حدوده ليؤثر على العالم المحيط

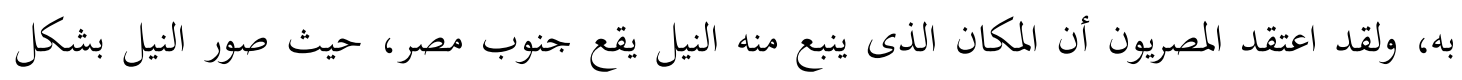
ثنايا وهو ما يمثل ثنايا جسم الثعبان للاعتقاد بحراسته لمنابع المياه فيما قبل التاريخ بالإضافة إلى ان في

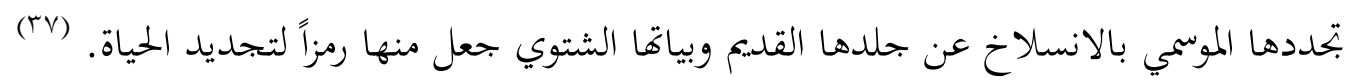
(") ثناء جمعة محمود الرشيدي، 1991 : الثعبان ومغزاه عند المصري القديع من البدايات الأولى وحتى غاية الدولة الحديثة، رسالة دكتوراه

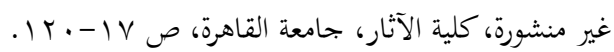

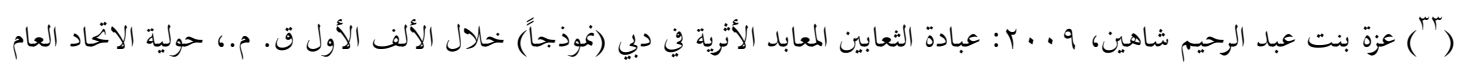

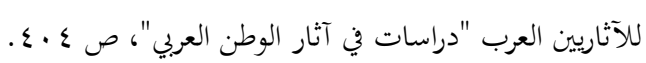
( $^{34}$ ) Saied Götterglaube Und Göttheiten in Der Vorgeschichte Und Frühzeit Ägyptens. ${ }^{35}$ ) Wilson 1999: 16.

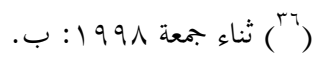

$\left({ }^{37}\right)$ Gimbutas, 1989: The Language of the Goddess, San Francisco, p.123

$$
\text { وليم نظير، } 971 \text { 1: الثروة النباتية عند قدماء المصريين - القاهرة، ص } 17 \text {. } 17 .
$$


بدأت تماثيل الثعبان في مصر، وبدأ بعضها في الانتشار في العديد من الأماكن الأخرى، ورغم أن

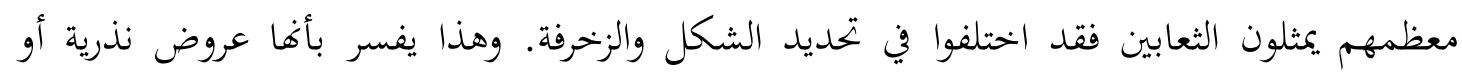

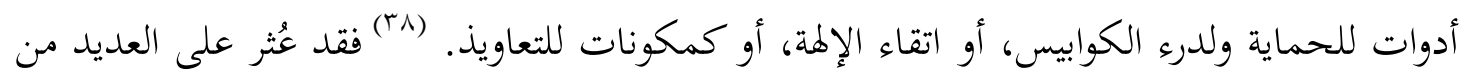

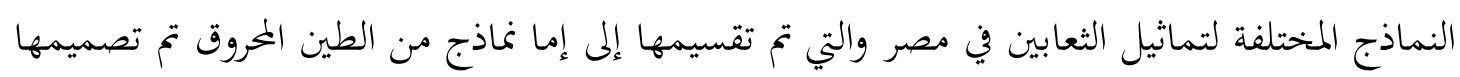

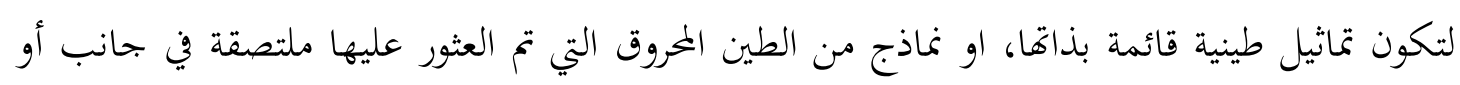

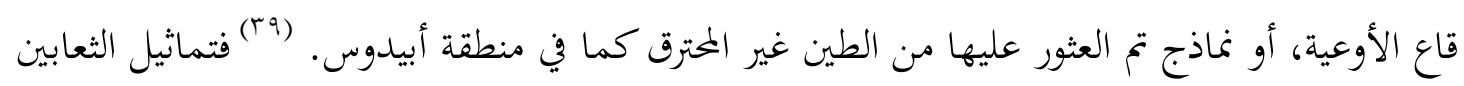

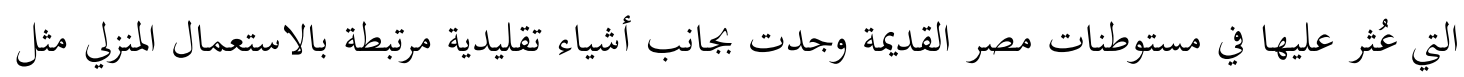

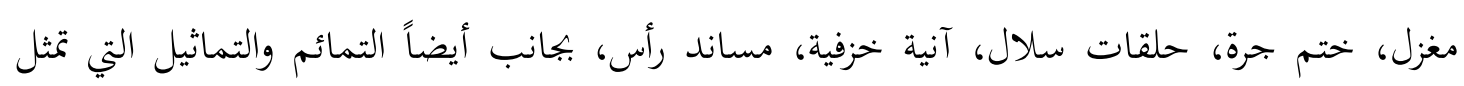

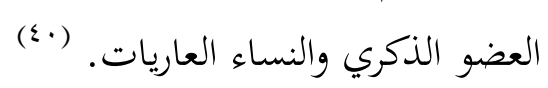
ظهرت البقايا الطينية في المستوطنات والمراكز العسكرية والإدارية على طول البحر المتوسط من ليبيا إلى لي

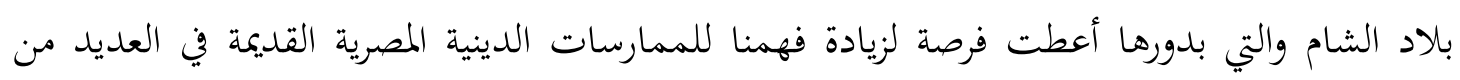

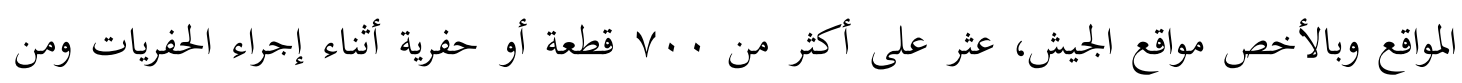

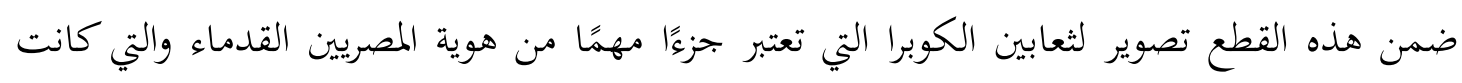

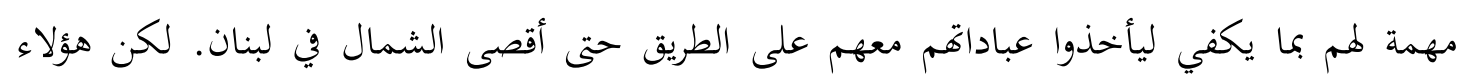

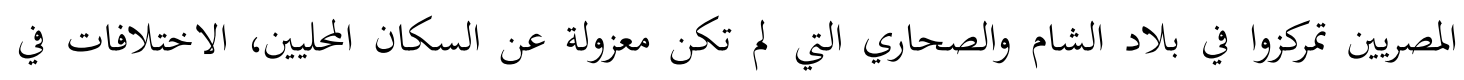

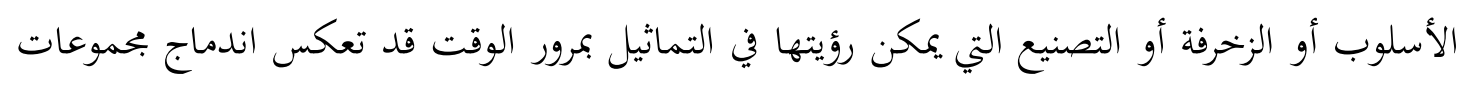

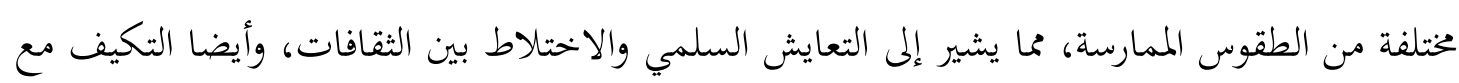

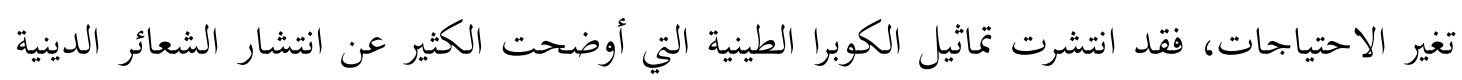

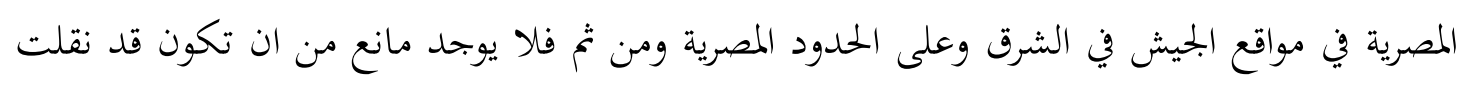
هذه الثقافة إلى الجزيرة العربية).

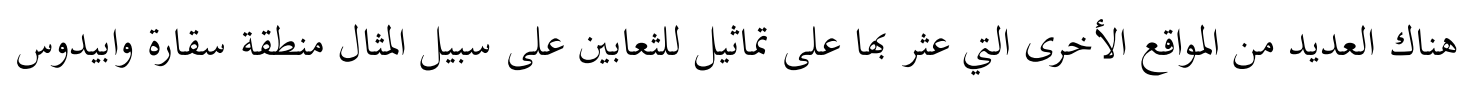

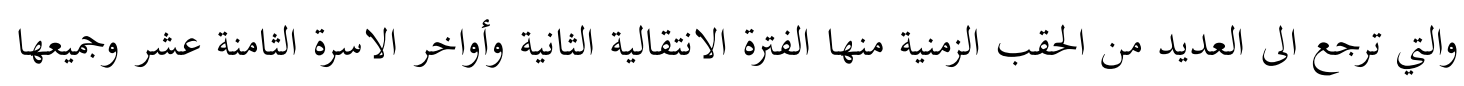

$\left(^{38}\right)$ Kasia Szpakowska, 2012: Striking Cobra Spitting Fire, Archive Für Religionsgeschichte, 14: p. 27-46.

(9) Kasia Szpakowska, 2015: Snake cult and Egyptian military bases, Koninklijke Brill NV, Leiden, Boston, p. 277.

$\left(^{40}\right)$ Peet, T., E., and Woolley, C., L., 1923: The city of Akhenaten I, London, Egypt exploration society, p. 79-90.

$\left({ }^{41}\right)$ Kasia 2015: 274-275. 
مصنوعة أما من الصلصال او الطين الغير محروق أو المحروق وجميعها قد يمثل مظهرًا محليًا مصممًا كاستجابة للاحتياج الخاص. (5i) وتدل الشواهد الاثرية على انتشار تماثيل الثعابين في العديد من الفئات الاجتماعية، مثل الجنود والحرفيين والنساء والأطفال، وربما لعبت دورًا في نقل الممارسات الدينية وتطويرها. قد تكون تماثيل الثعابين والمعثورات المرتبطة بها هي فقط المظهر المادي لتلك الممارسات الطقسية التي لم تترك ورائها سجل نصي، لأن المعتقدات الدينية التي تكمن وراء هذه الطقوس والتي يتم عرضها من خلال هذه الطقوس هي بالضرورة أكثر صعوبة للتمييز فقط من خلال دراسة هذه البقايا. (rاء) والواقع أن غالبية تماثيل الثعابين التي عُثر عليها كانت في الأماكن المرتبطة بأماكن المعيشة، سواء كانت قرى وادي النيل، والمنشآت العسكرية في الدلتا، أو على حدود المناطق التي تدخل في دائرة النفوذ المصري وهذا يثير تساؤلات بشأن المستخدمين الأساسيين، حيث لم يكن الرجال هم السكان الوحيدون لمذه المواقع. النساء والأطفال قد يكونوا مشاركين نشطين أو حتى أشخاص أساسيين في الطقوس المرتبطة بها. يبدو من الواضح أنه لا يمكن ربط التمثال بمفرده مع الدين المحلي، إذا فهمنا كلمة "علي" للإشثارة

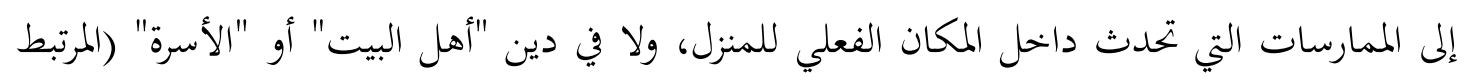

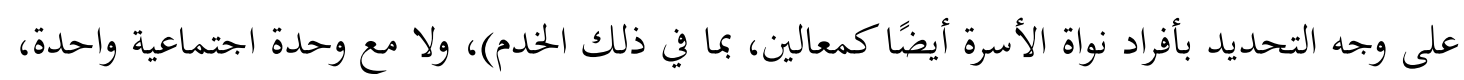
مثل الجيش. (ءء) ومن ثم يري الباحث أن معظم تماثيل الثعابين ربما تكون مرتبطة بالأماكن الأولية

$$
\text { للتواجد البشري، سواء كانت قرى أو حصون. }
$$

ومن أهم أنواع التماثيل التي عُثر عليها تلك التماثيل الصغيرة للثعابين التي شُكلت على شكل كوبرا

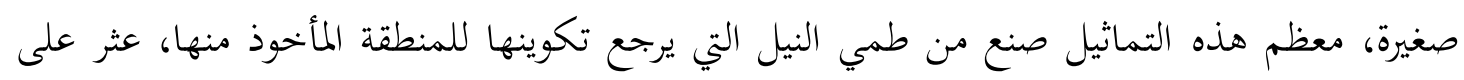
العديد منها في مناطق متعددة على سبيل المثال لا الحصر في تل العمارنة وفى منطقة القناطر، فقد عثر مثرئر هناك على تمثال مصنوعة من الطين علي شكل ثعبان الكوبرا الصغيرة (شكل رقم ا ) بين المستوطنات

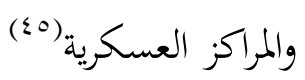
ففي منطقة تل العمارنة عُثر على العديد من تماثيل الثعابين ويبدو أن بعض من هذه التماثيل تفتقر الي الزينة، فقد كان من هذه التماثيل ما هو قائم بذاته ومنها من كانت تستخدم كجزء من الأوعية والتي

$\left({ }^{42}\right)$ Raven, M., J., 2012: Egyptian magic: the quest for Thoth's book of secrets, Cairo, American university of Cairo, p. 117.

$\left({ }^{43}\right)$ Kasia 2015: 275.

$\left({ }^{44}\right)$ Sweeney, D., 2009: gender and oracular practice in Deir El-Medina, Zeitschrift für Ägyptische sprache und altertumskunde 135/2, p. 154-64.

( $\left.{ }^{45}\right)$ Kasia 2015: 277. 
كان من الممكن أن تحتوي على زيت وتُشعل، وتستخدم كمكونات لتعاويذ لدرء الشر ولحماية الغرفة أو سكاغا من قوى شيطانية معادية، فتعتبر منطقة تل العمارنة من أكبر المناطق في مصر القديمة التي بها

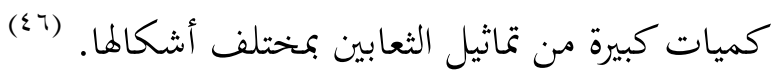
ومن الملاحظ ان العديد من المواقع التي عثر فيها على تماثيل الثعبان الطينية تحتوي على مخازن حبوب أو صوامع، وهذا يدفعنا الى التوقع بأن المصريين اصطحبوا عاداهم الدينية معهم واستمروا بالزواج بطقوسهم المرتبطة بها، فقد أقاموا العديد من الاحتفالات التي تح فيه تغطية تلك التماثيل بالأكاليل. في حين أن بـان تماثيل الالمة في مصر يتم وضع الاكاليل بواسطة الكهنة، المصنوعات الطينية تحضر إلى المعبد الرئيسي أو تزين في ركن العبادة في المنزل، ولذلك بحد أن بعض من تماثيل الثعابين مزينة بأكاليل (شكل رقم ؟ ب). كما وجد طبقات من الجبس الأبيض أو البلاستر (خليط من الجبس والرمل) على كثير من هذه التماثيل

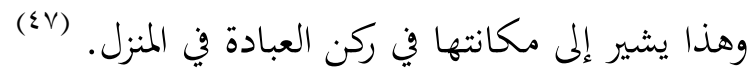
أما عن ظهور الثعابين في مصر القديمة على شكل تمائم فيرجع تاريخه الى الفترة الانتقالية الثالثة -الفترة

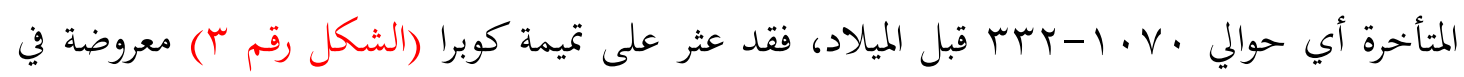

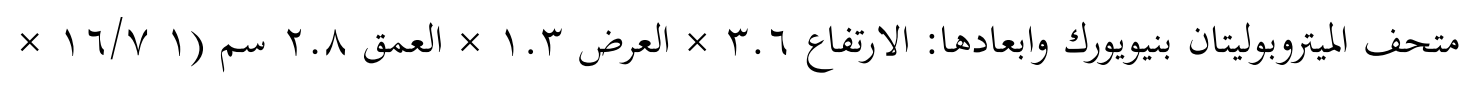

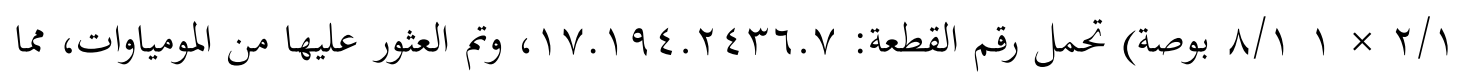
يشير بوضوح إلى الصل الملكي الواقي الذي يرتديه الفرعون على جبهته والذي أصبح رمزًا للقوة. ولكن تم العثور عليها في كثير من الأحيان في أماكن أخرى من الجسم ويمكن وضع العديد من تمائم الكوبرا

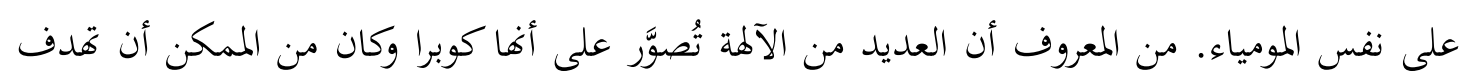
هذه التميمة إلى وضع مرتديها تحت حماية مثل هذا الإله. قد تتصل الكوبرا أيضًا بالتجديد لأهنا تتخلص من بشرقا، وكان من الممكن أن تمدف هذه التميمة إلى نقل هذه الجودة إلى مرتديها. بالإضافة إلى ذلك، من الممكن أن يكون تصوير الكوبرا قد استخدم لدرء لدغات الثعابين. وفقًا لمبدأ سحري بـري مصري قديم، يمكن استدعاء الشيء الذي يهددك لحمايتك من هذا التهديد وربما تتناول تمائم الكوبرا مثل هذا معاني مختلفة، ويمكن أن يكون لها وظائف مختلفة لأفراد مختلفين أو ربما وظائف متعددة

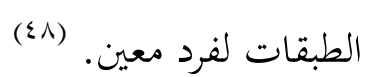

( $\left.{ }^{46}\right)$ Stevens, A., k., 2006: Private religion at Amarna: the material evidence, bar international series 1587, Oxford, Archaeopress. P. 22.

$\left({ }^{47}\right)$ Kasia 2015: 285.

$\left({ }^{48}\right)$ https://www.metmuseum.org/art/collection/search/550931

الموقع الالكتروني الرسمي لمتحف الميتروبليتان 
كما عثر على تميمة كوبرا أخري (الشكل رقم ع) ربما يعود تاريخها الى فترة العصر البطلمي . . ع-..ب

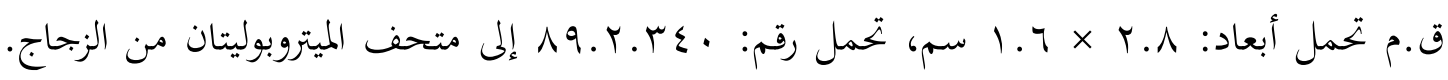
فقد بدء خلال العصر البطلمي يظهر نوع من التميمة الزجاجية المصبوبة عن طريق ضغط الزجاج في قالب مفتوح ضحل. تم ترك الجزء الخلفي خشنًا، وقد تبدو التمائم ممزقة لأن الزجاج فاض بالقالب حؤل (الحواف. (29)

لم يقتصر تمثيل الثعبان في هيئة التماثيل والتمائم فقط بل ايضاً تم تمثيل الثعبان في الألعاب فقد عثر على ألعاب طاولة كلعبة الثعبان هذا بجانب العديد من الألعاب التي كان يلعبها الأطفال القدماء كلعبة مشابهة للشطرنج فمن خلال بعض المشاهد التي نقشت على جدران المقابر نفهم أن الأطفال كانوا

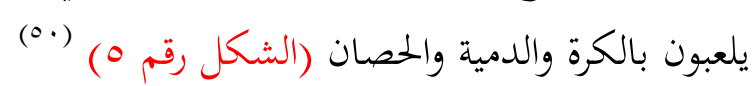

كما عُثر في مدينة الأقصر بمصر أيضا على رأسي ثعبانين معروضين في متحف الآثار في مكتبة

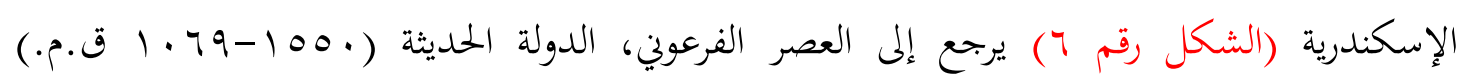

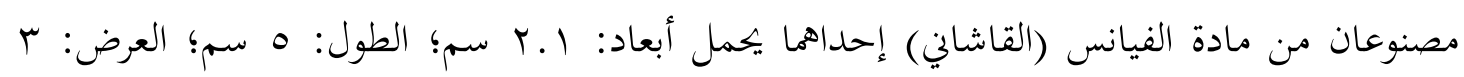

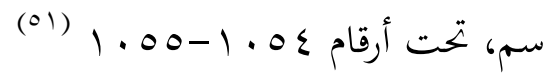

$\left({ }^{49}\right)$ https://www.metmuseum.org/art/collection/search/552978

الموقع الالكتروني الرسمي لمتحف الميتروبوليتان $\left(^{50}\right)$ Latifa Tazzit,: La Vita Quotidiana Nell'Antico Egitto, Collaborazione Museo Egizio -Mondi In Citta Onlus, Feste, Musica, Sport e Divertimento, p. 66 $\left.{ }^{51}\right)$ http://antiquities.bibalex.org/Collection/Detail.aspx?lang=ar\&a=1054 http://antiquities.bibalex.org/Collection/Detail.aspx?lang=ar\&a=1055

الموقع الالكتروني الرسمي لمكتبة الاسكندرية 


\begin{tabular}{|c|c|}
\hline د/سمر حماد فهيم & العدد الخامس والعشرين يونيو ا Y · Y م \\
\hline
\end{tabular}

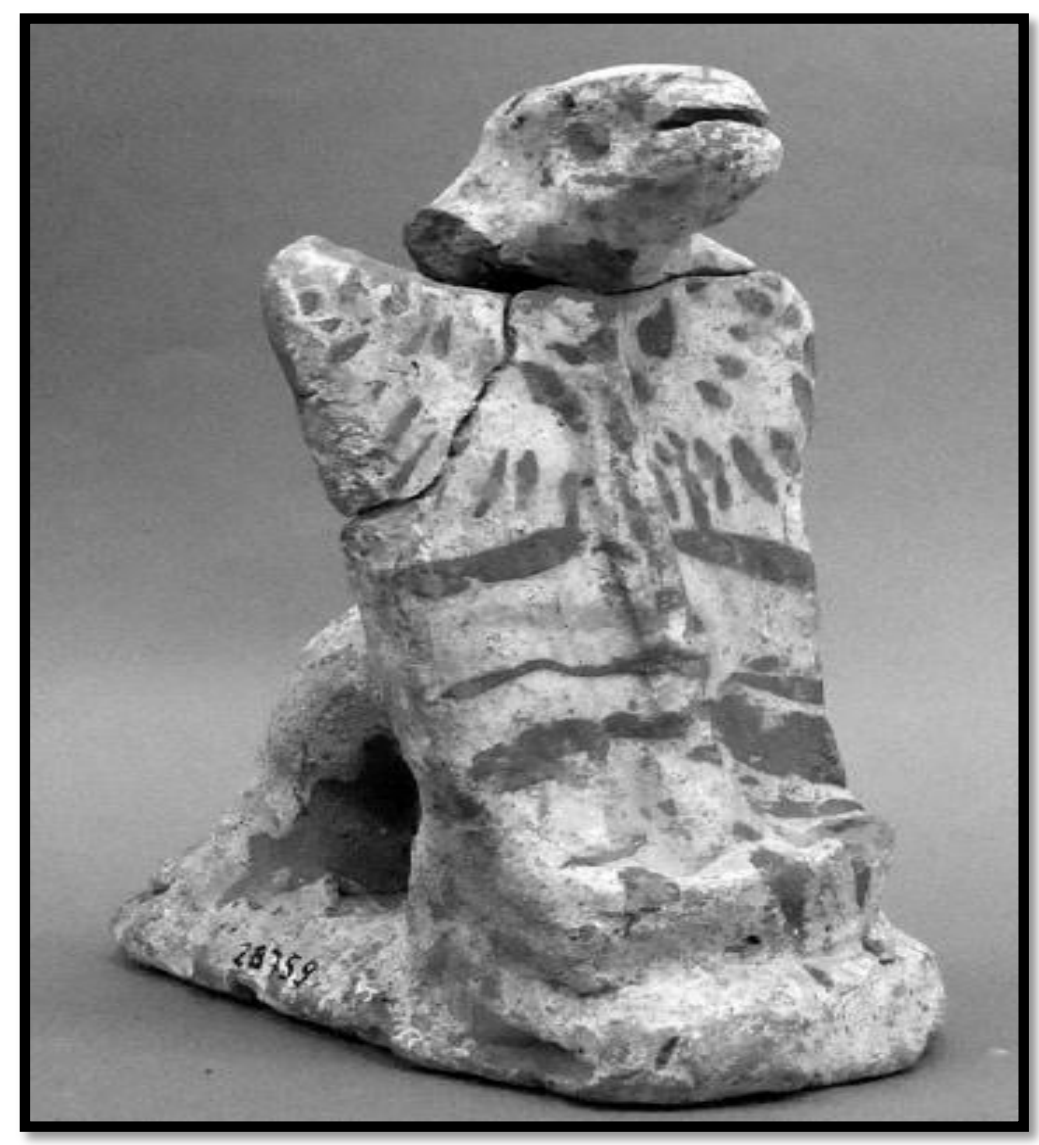

$$
\begin{gathered}
\text { (الشكل رقم ( ) تمثال كامل لثعبان الكوبرا من العمارنة } 290 \\
\text { Kasia 2015, fig.:1 } 290
\end{gathered}
$$

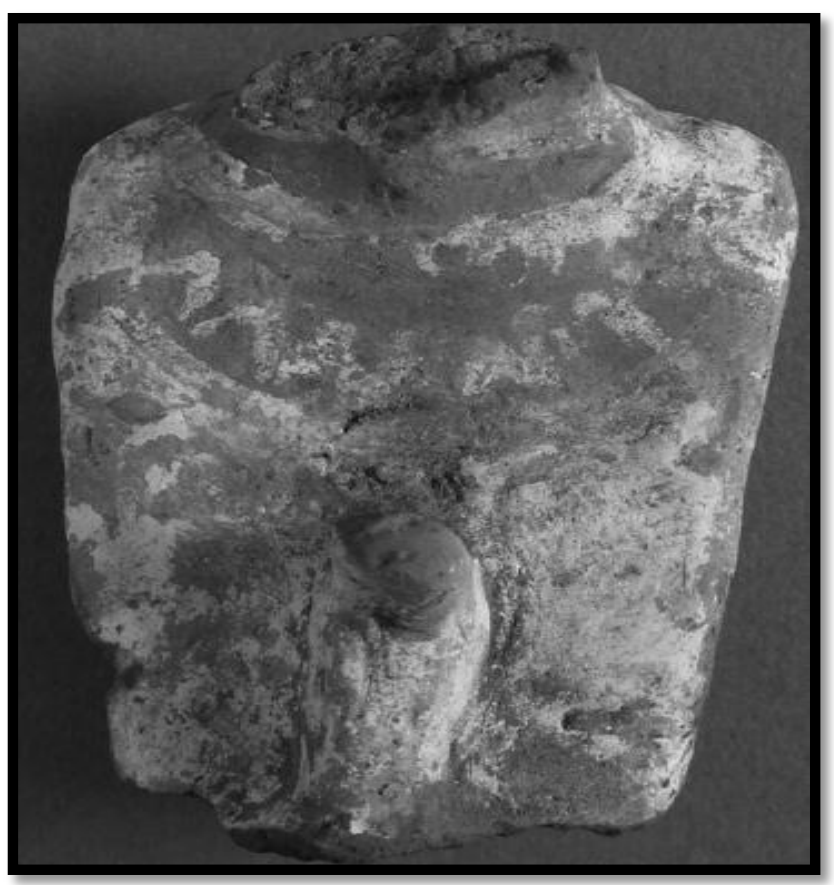

$$
\text { (الشكل رقم r) تمثال ثعبان الكوبرا من العمارنة }
$$

Kasia 2015, fig. 3: 291 


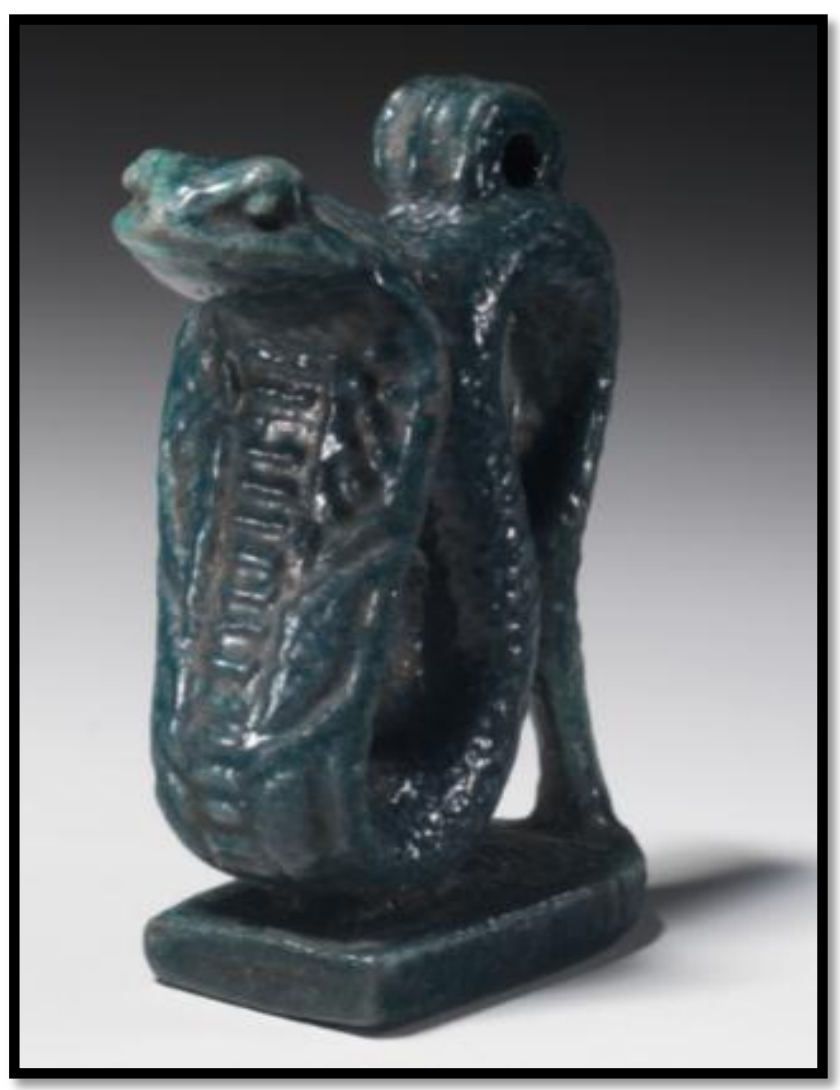

$$
\begin{gathered}
\text { (الشكل رقم ب) تميمة كوبرا معروضة في متحف الميتروبوليتان } \\
\text { الموقع الرسمي الالكتروني لمتحف الميتروبوليتان }
\end{gathered}
$$

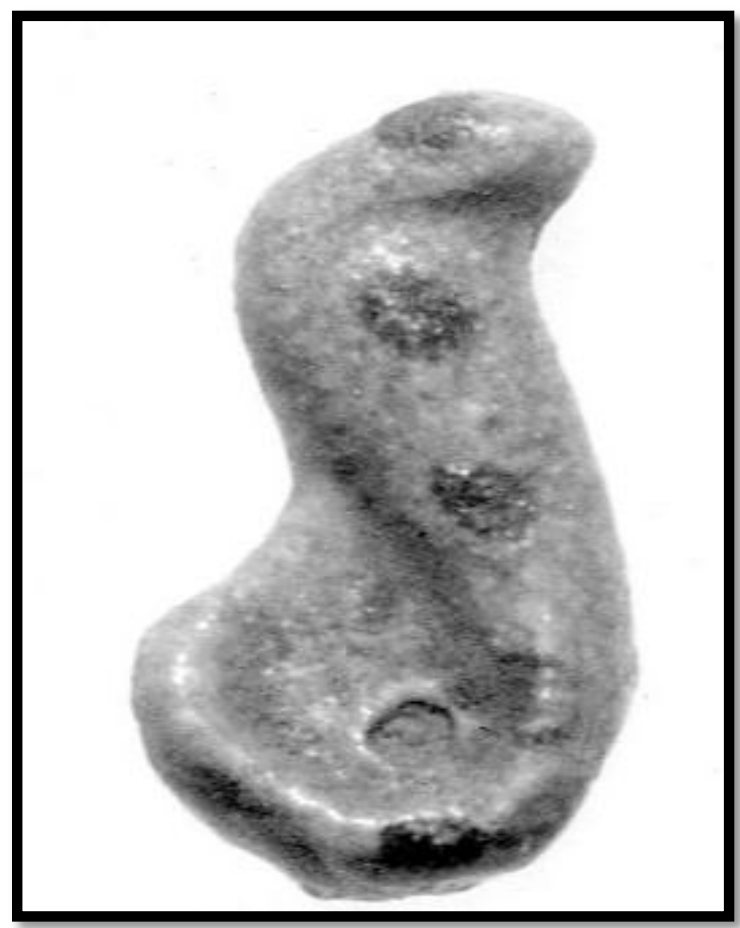

$$
\begin{gathered}
\text { (الشكل رقم ع) تميمة كوبرا معروضة في متحف الميتروبوليتان } \\
\text { علموقع الرسمي الالكتروين لمتحف الميتروبوليتان }
\end{gathered}
$$




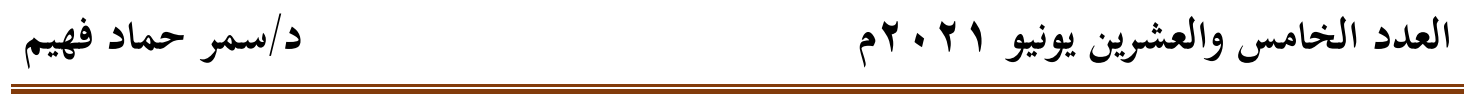

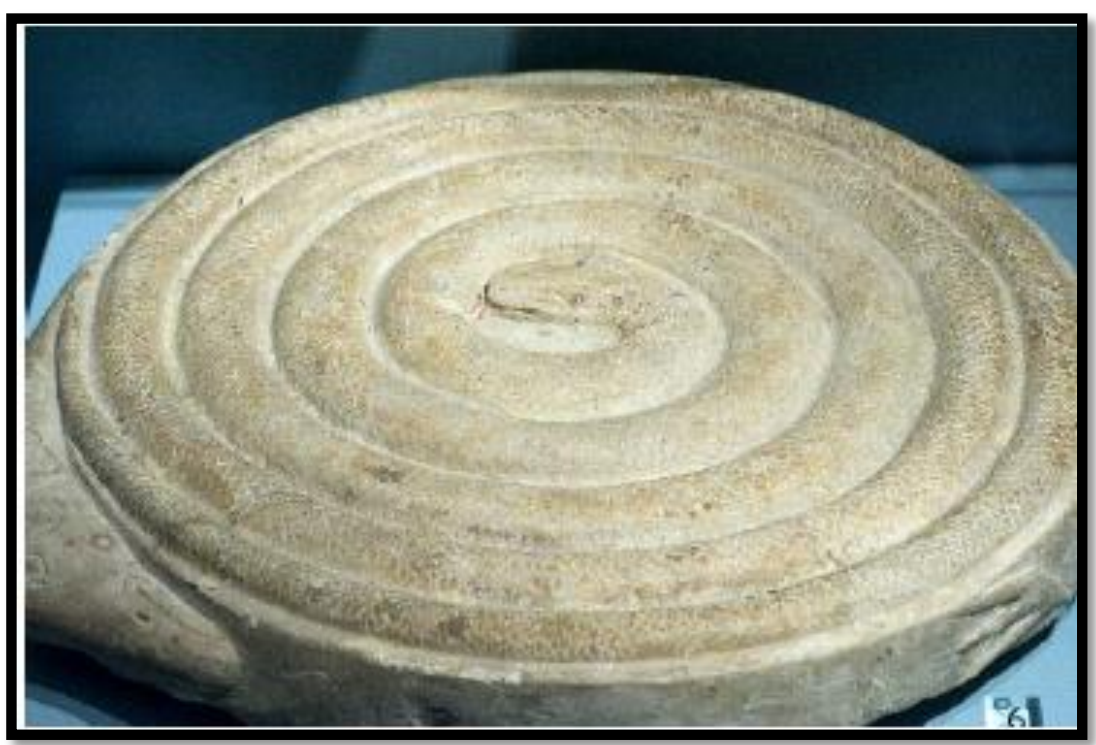

(الشكل رقم 0) لعبة الثعبان المصرية القديمة

Latifa Tazzit: 66
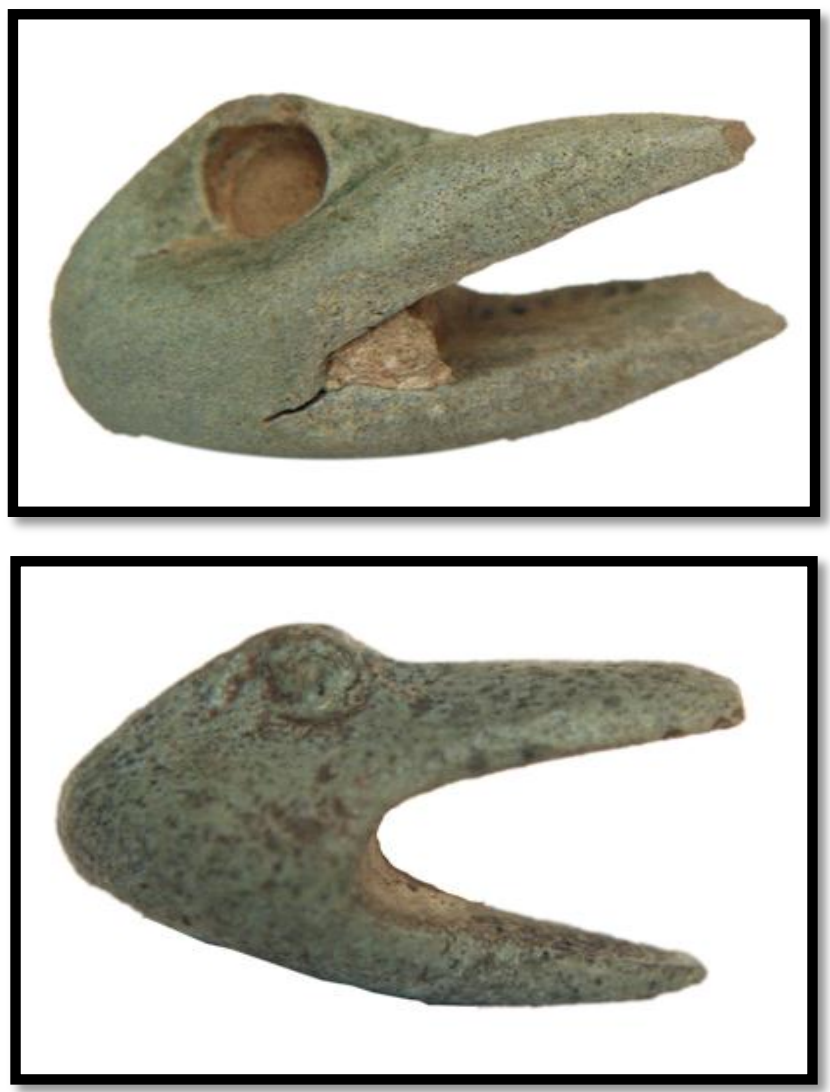

$$
\text { (الشكل رقم 7) رأسي ثعبانين من مصر الاثار في مكتبة الإسكندرية }
$$


وتشير الشواهد الأثرية العديدة أنه خلال عصر الدولة الحديثة تم المزج بين الإلهة إيزيس والإلهة "رنينوتيت" والتي كانت تصوَّر على هيئة ثعبان، وكانت تلك الأخيرة على صلة وثيقة بخصوبة الحقول. واصبحت علاقة الإلهة إيزيس بالحقول شائعة بشكل ملحوظ خلال العصر اليوناني، وكانت إيزيس تُصوَّر، سواءً على العملات أو على بعض الوثائق التي ترجع للقرن الثاني الميادي، في شكل كوبرا

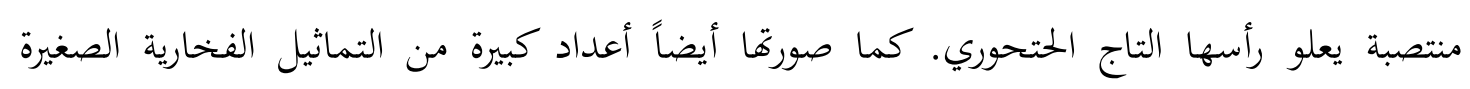

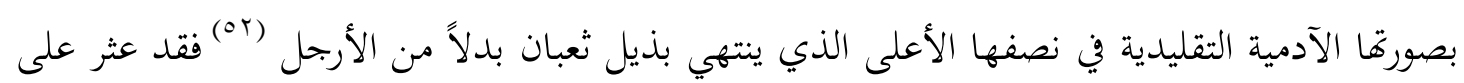
لوحة للإلمة إيزيس - ثرموتيس (الشكل رقم V) ربما هذه القطعة ذات استخدام ديني أو طقسي، ترجع الى العصر الروماني، القرن الثاني الميلادي وموقع اكتشافها في الإسكندرية، أبو قير، من مادة الرخام تحمل أبعاد r سم - - r سم والعمق T سم ومعروضة في متحف الآثار بمكتبة الإسكندرية في قاعة:

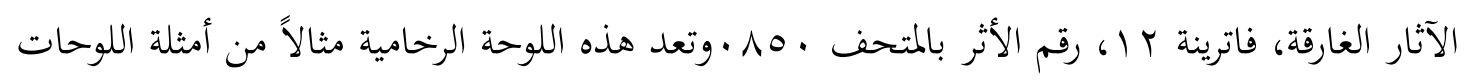
الدينية التقليدية التي كانت تكرس لعبادة الإلهة إيزيس وهنا تعتبر إيزيس-ثرموتيس التي تُصوَّر على هيئة الكوبرا. (or)

عُثر أيضا على رأس أفعى في مصر مصنوعة من الخزف المصري في متحف المتروبوليتان (الشكل رقم ^)،

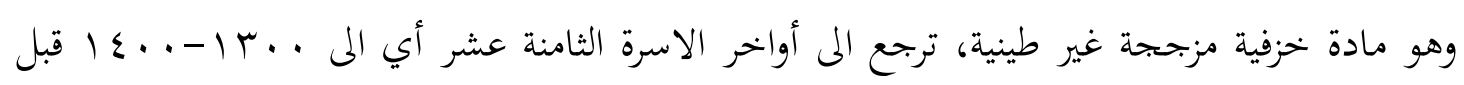

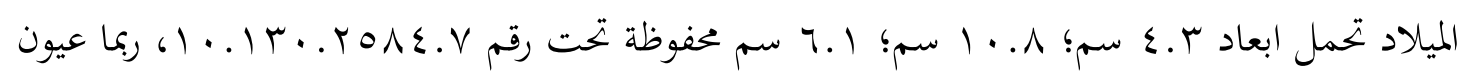

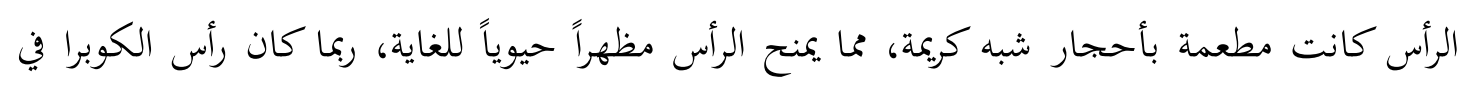
الأصل جزءاً من إفريز من الصلصال ينتمي إلى قطعة من الأثاث الخشبي. فمثل هذه اللقى متواجدة في أثاث توت عنخ آمون، وربما ايضاً كان رأس الكوبرا ينتمي إلى معدات الدفن لملك آخر في في هذه الفترة.

$\left(^{52}\right)$ Franck Goddio \& Manfred Clauss, eds., 2006: Egypt's Sunken Treasures, photographs by Christoph Gerigk (London: Prestel): p. 390-391, 408.

$\left({ }^{53}\right)$ http://antiquities.bibalex.org/Collection/Detail.aspx?lang=ar\&a=850\#

$\left({ }^{54}\right)$ https://www.metmuseum.org/art/collection/search/544121

$$
\text { الموقع الالكتروني الريمي لمكتبة الاسكندرية }
$$

الموقع الالكتووني الرسمي لمتحف الميتروبوليتان 


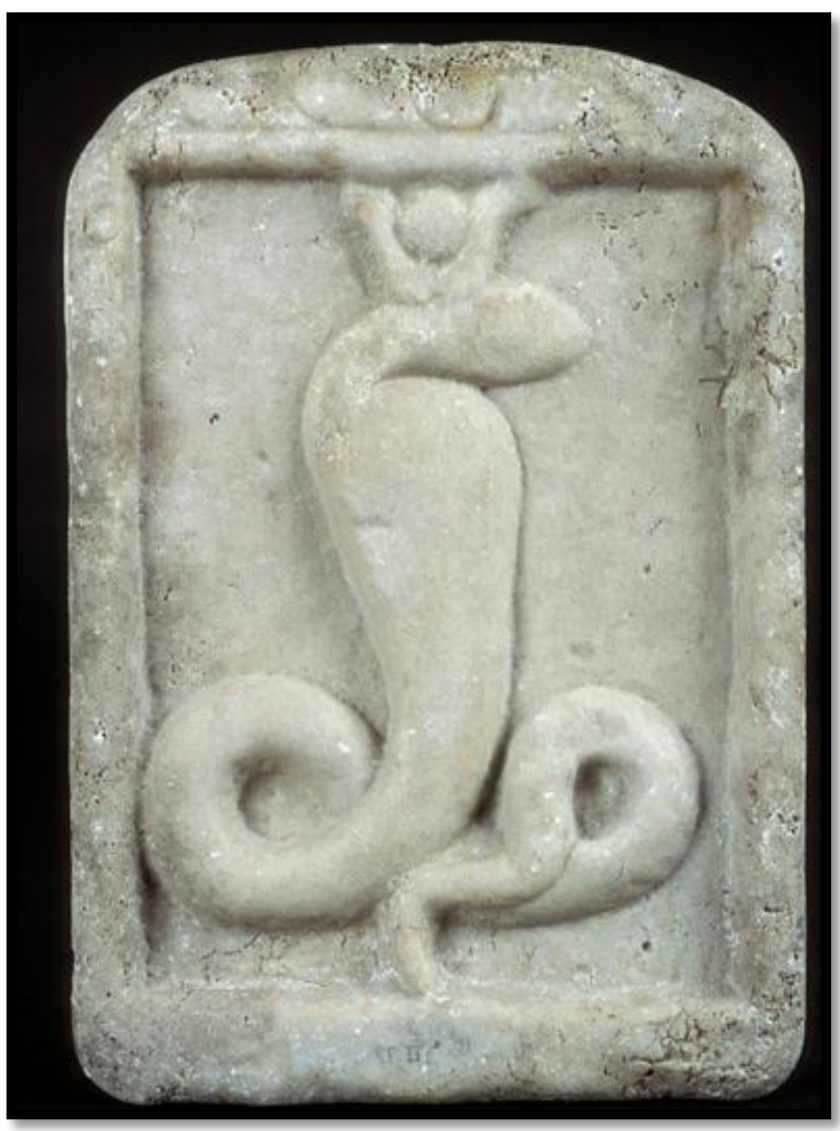

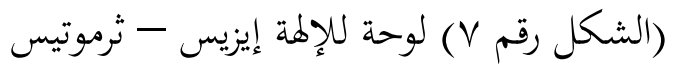

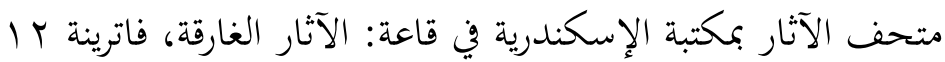

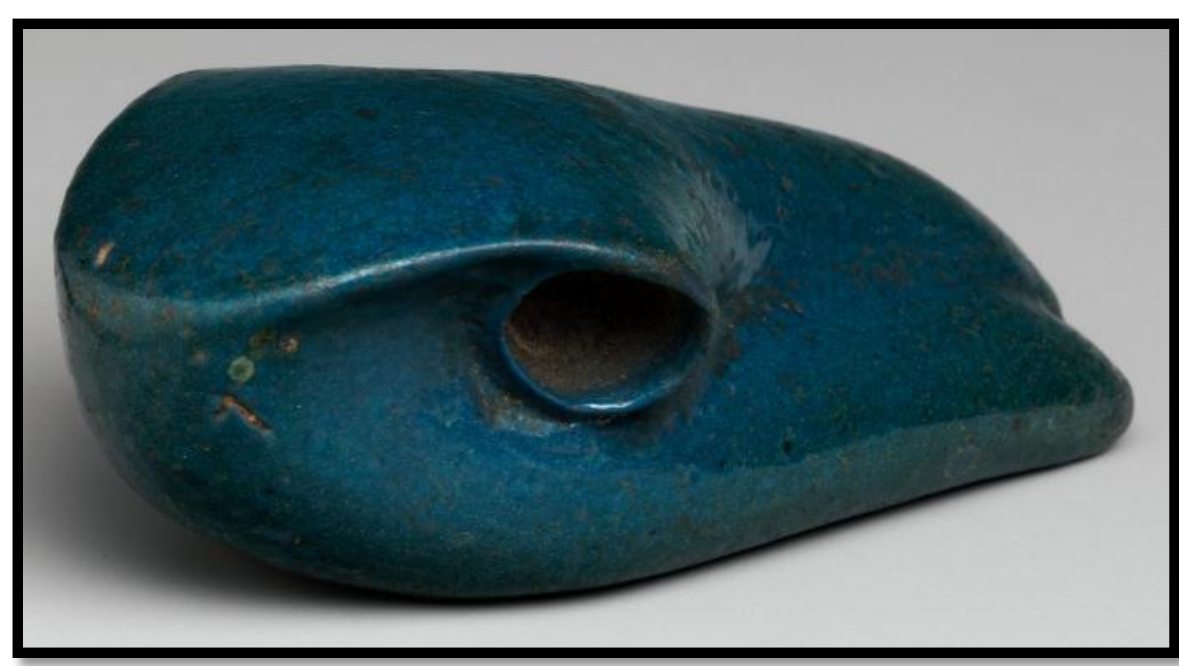

$$
\begin{aligned}
& \text { (الشكل رقم ^) رأس أفعى في مصر مصنوعة من الخزف المصري } \\
& \text { متحف المتروبوليتان }
\end{aligned}
$$


من خلال ما سبق يتبن أن الفنان المصري القديم لاحظ جسم الثعبان سواء كجسم انسيابي يتحرك في انسيابية وسهولة أو كثعبان متحفز منتصب متوازن مرفوع الرأس ودرقته منفوخة قوية متوعدة إذ بند هناك تأثر واضح في فنه، حيث أبدع في نقشه ونحته لاعتقاده بأن الروح الحية للثعبان تتقمص اعماله، وكنتيجة بالطبع للملاحظة الدقيقة للكوبرا في الطبيعة استلهم تصوير الحية كإلهة مؤثرة خالدة (00) فكان لإعجاب المصري القديم الشديد بالثعبان أثرا واضحا في وضعه في مكانه بارزه بالنسبة لفكرة وعقيدته وهو أمر فرضته خصائص البيئة المصرية المتنوعة التي ادت لقيام اعرق الحضارات، حيث قام المصري القديم بمراقبة سلوكياته وحركته الفجائية السريعة وبحديده لجلده ولدغة لفرائسه بلدغات قاتله وابتلاعه لها وخير دليل هو كتابة التعاويذ الوقائية في المقابر، لمنع الثعبان من مهاجمة الموتى والتي تعتبر وسيلة واضحة لترويض ذلك الثعبان واجباره على الخضوع الكامل للأوامر الموجه اليه، حيث قدس في الحياة الملموسة للخوف والرهبة منه، واتخذ كتميمة يلبسها الاحياء وتوضع مع الأموات لتجنب خطورته إلى جانب تصويره في مقابر وتوابيت. وامتد الفكري المصري القديم لأبعد من ذلك حيث رأى فيه صوره الاله

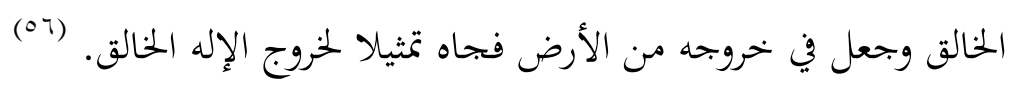
تمكن المصري القديم من خلال الرموز التعبير عن معتقداته الدينية وأفكاره المستمدة من المنظومة الكونية وفي مرات عديده يستخدم الرموز لتفسير عمليه الخلق وما ارتبط بها من صعوبات ومعوقات في تطورها واستمرارها وتفسيرها بل عبرت تلك الرموز في بعض الأحيان عن حمايه المصري القديم من شرور الحياه وما بعدها فقد كانت أغلب رموزه مستمده من حيوانات وطيور وزواحف والنباتات مثل الثعابين والصقر

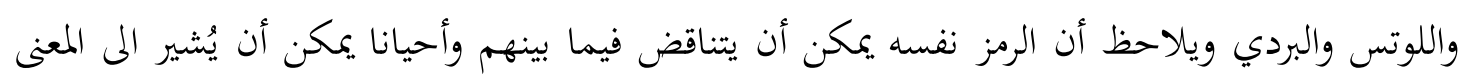

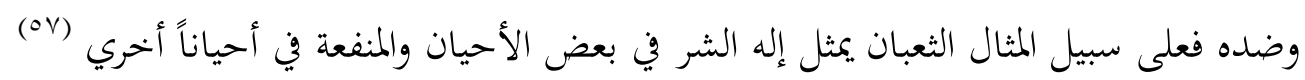
ربما المغزى الرمزي للثعبان في الديانات القديمة يرجع إلى دورة حياة الثعبان الطبيعية، حيث ينسلخ عن

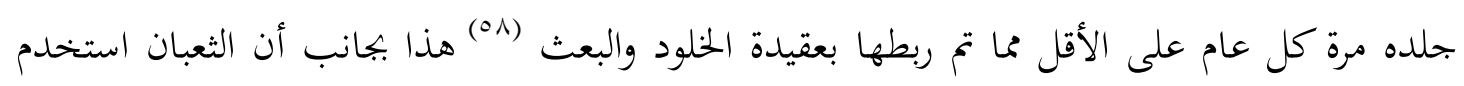
كرمز للمعبود الخالق لما له من خصائص تتمثل في السرعة المفاجئة التي تشبه البزوغ الفجائي في لحظة

$\left(^{55}\right)$ Schafer, 1974: Principles of Egyptian Art, (Trans. by J. Baines), Oxford, p. 38; Smith, 1981: The Art and Architecture of Ancient Egyptian, New York, P. 15.

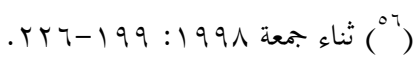
(V) مني الشايب، (999 19: الرموز المقدسة في أدوات التزين في مصر القديمة حتى خاية عصر الدولة الحديثة، رسالة ماجستير غير منشورة، القاهرة، ص 9-11 11. $\left(^{58}\right.$ ) Piccione, A., P., 1990: Mehen, Mysteries and Resurrection from the copied serpent, JARCE, 27, p. 43-52.

$\left({ }^{59}\right)$ Mysliwiec, k., 1979: Studien Zum Got Atum, in HÄb 8, Hildesheim, p. 131-134. 
طبقا لعقيدة المصري القديم كان الثعبان يعمل على بتحيد او إعادة ميلاد الشمس داخل جسمه الذي يحيط بالعالم كما ذكرت الساعة الثانية عشرة الليلة من كتاب الأمي دوات، فهو يُعد بمثابة رمزاً مرئياً للأبدية والتجدد في الكون، حيث يدخل مركب الشمس من ذيل الثعبان وتسافر عبر عموده الفقري وتخرج المركب بعد إعادة الولادة من فم الثعبان، وترمز هذه الرحلة لعملية إعادة الولادة وتعاقب الزمن لاستمرار دورة الكون وبتحيد الحياة من الشيخوخة إلى الطفولة ومن الموت إلى الحياة والثعبان يجسد إنداد الزمن والأبدية (7.) (1) (1) طبقاً للمعتقدات القديمة ارتبط الثعبان بدورة الشمس، حيث يساعد إله الشمس في البعث خلال رحلته الليلية وبذلك يكون له دور كبير في عملية البعث والتجديد والحفاظ على الأبدية فالثعبان يحاول جاهداً الحفاظ على نظام الكون ودورة الزمن لتستمر الحياة على الأرض، بالإضافة إلى أنه قادر على إبعاد الشر عن إلالة الرئيسي للمصري القديع. (11) ربما أثرت حضارة مصر القديمة في شرق الجزيرة العربية بطريق مباشر عن طريق التجارة او بطريق غير مباشر عن طريق وسطاء من بلاد النهرين ففي موقع ساروق الحديد عُثر على تميمة على شكل جعران، حيث اعتقد المصري القديم أهما تقوم ببناء نفسها بنفسها واخذ منها تميمة فرعونية له وأصبحت من أهم التمائم الفرعونية لارتباطها بالشمس، هذا الجعران من الخزف قُسِّم الظهر بشكل مربعات نافرة فصلت عن بعضها بأخاديد، وظهرت تفاصيل الوجه؛ عينان على شكل دائرة مزدوجة، بينهما بروز

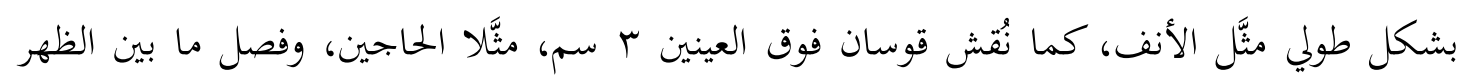

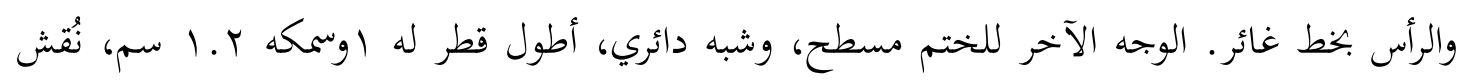
عليه شكل مروحة من أربعة أجزاء، كل جزء ذو شكل شبه بيضاوي، يلتقيان في المركز، وقُسم كل جزء اله

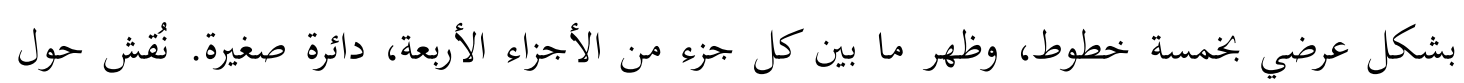
الشكل بمجمله إطار دائري غائر، وكذلك على جانبي التميمة شكل أفعى ملتوية، وتم إبرازها بحفر

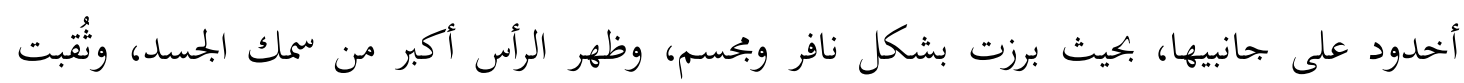

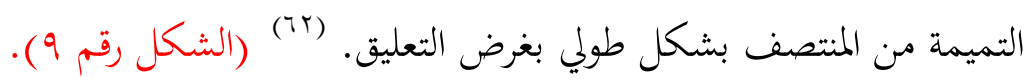

$\left({ }^{60}\right)$ Horning, E., 1963: Das Amduat, Die Schrift des Verborgenen Raumes, Wiesbaden, p.91.

(1) Piankoff, A., 1956: The Theology of the new kingdom, Le Caire, p. 492.

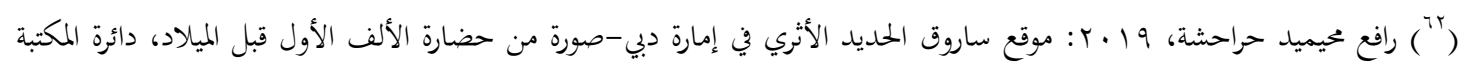
الوطنية، الأردن، الطبعة الأولى، ص حراحثة 109 


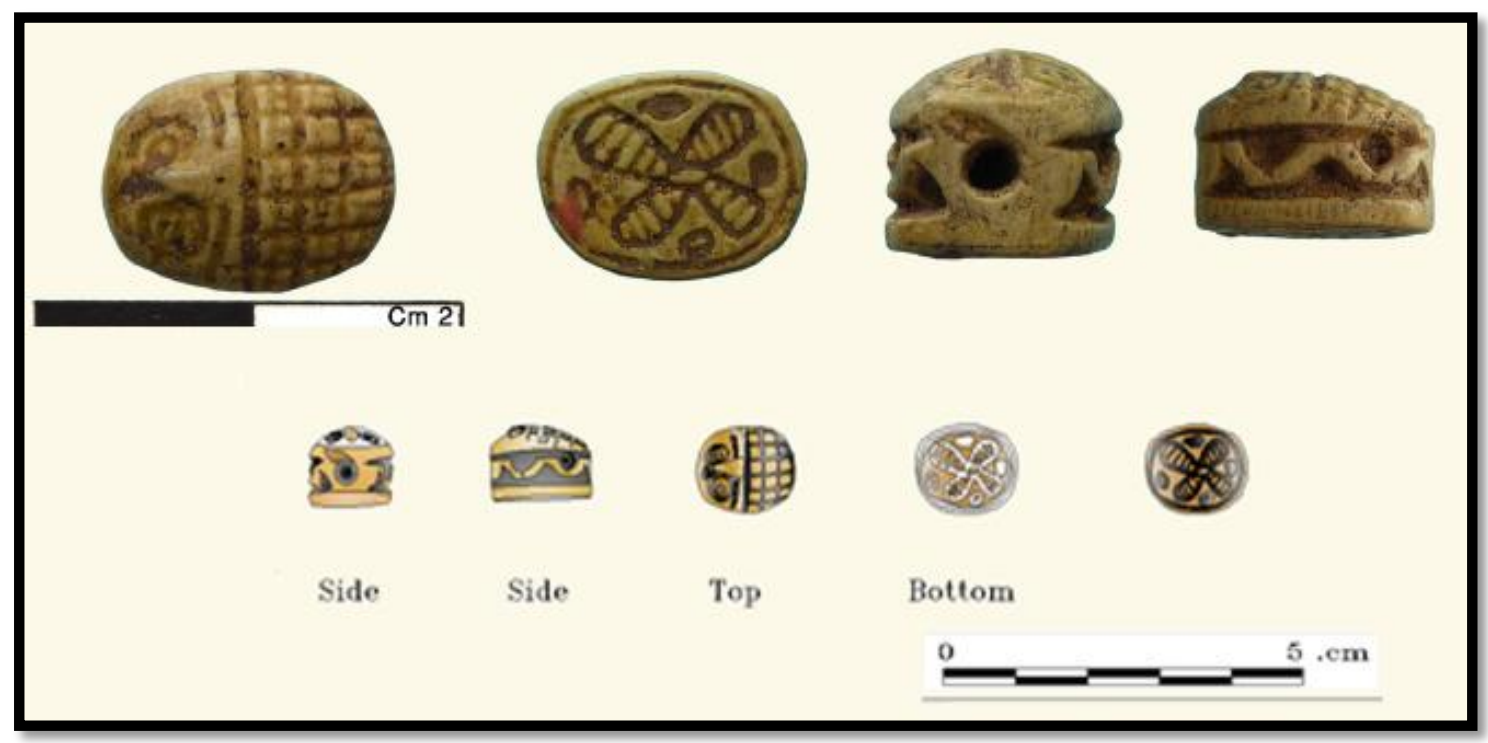

$$
\begin{aligned}
& \text { (الشكل رقم 9) }
\end{aligned}
$$

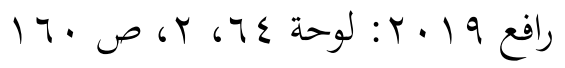

ثالثاً: الثعبان في مجان: -

تعددت وتنوعت الدلائل الأثرية لنماذج الثعابين التي تم اكتشافها في منطقه شرق الجزيرة العربية ما بين الفخار أو الحجارة فكان هناك بعض النماذج من البرونز والنحاس والزجاج ونوى التمر هذا بالإضافة الى بقايا عظام الثعابين وهذا يدل دلاله واضحة على استخدام الثعبان في ديانات او عبادات تلك المنطقة.

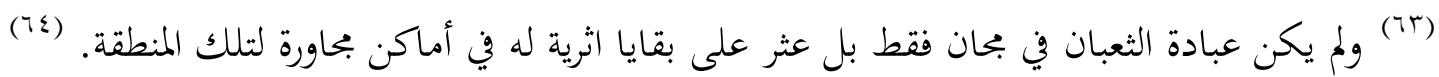
وقد اسفرت الحفريات العديدة التي أجريت في بحان العثور على العديد من تماثيل الثعبان وكذلك العثور على الأواني المزخرفة بالثعابين، فربما استخدمت هذه الأواني في العديد من الأغراض الدينية، وقد يُعسر وجود زخرفة الثعابين على جرار التخزين كنوع من الممارسة السحرية لحماية محتويات الجرار من الآفات والقوارض وغيرها، كما أن الحجم الصغير للثعابين البرونزية ربما كانت توضع بالدرجة الأولى في الجرار وبين الحبوب لغرض الحماية وربما أيضاً في مخازن المحاصيل الزراعية. (70)

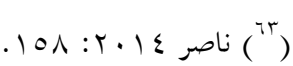
(ع 7) منير يوسف طه، و 919 ا: "اكتشاف العصر الحديدي في دوله الإمارات العربية المتحدة" ، مركز دراسات الخليج العربي ، جامعة

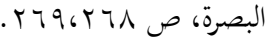
( ) فواز الخريشة، خالد الناشف، V V . . Y : دبي حضارة وتقدم عبر ثلاثة آلاف عام، خمسة مواسم من التنقيبات الأثرية المشتركة بين إمارة

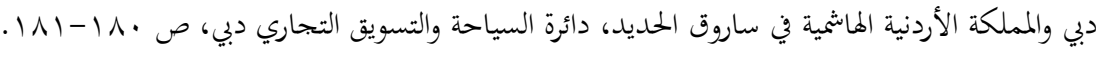


العديد من المواقع الأثرية في بحان قدمت دلائل لوجود الثعبان في عصور ما قبل التاريخ حتى وان كان اغلب هذه المواقع لم تقدم الكثير من الدلائل الأثرية، وقد قدمت بضع دلائل، فقد تم احصاء عشرات

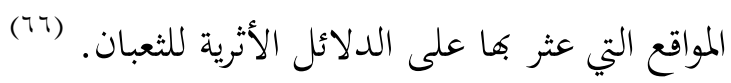
بما اننا نتحدث عن منطقة تتمتع بصحاري ممتدة ومرتبطة بصحراء الجزيرة العربية، فان الثعبان في هذه المنطقة الرملية من الزواحف الظاهر في الحياة ومتواجد بكثرة حتى في الوقت الحاضر، فمن الطبيعي ان كان يشاهد الأجداد الثعابين، وربما كانوا يقدسوها وهذا ما شاهدناه في اللقى الاثرية خصوصاً الأواني والحلي وقد تكون كل هذه الأشياء مستجلبة من خارج المنطقة، وربما هم اغتنموها من تجارها الذين أتوا بها من خارج حدود المنطقة ولكن بعد الدراسة تبين ان بعض الاواني صناعة محلية.

\section{- موقع ساروق الحديد: - مارئ}

يعتبر موقع ساروق الحديد من اهم المواقع التي عثر فيها على ثعابين مصورة على فخار او تماثيل فهناك العديد من النظريات والتساؤلات التي تحيط بموقع ساروق الحديد من أهمها وجود تماثيل الثعابين بكميات كبيرة فالمعتقد أن سكان موقع ساروق الحديد مارسوا حرفة صناعة تماثيل الثعبان او الفخاج المجسد علية تماثيل الثعابين كنوع من أنواع الدلالات الاجتماعية أو الثقافية المعينة وكان الحصول على المواد الخام متوفر بكثرة بسبب موقع ساروق الحديد الجغرافي بالرغم أن الموقع يوحى كأنه معزول للوهلة الأولى، لكن

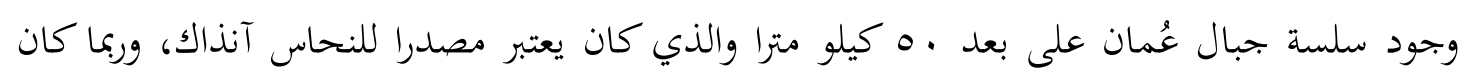
مصدرا للحطب أيضا، حيث كان يستخدم الحطب لصهر الحديد بسبب توافره بكثرة قرب الجبال ، كل هذا ساهم بزيادة إنتاجيه سكان ساروق الحديد آنذاك. عُثر في ساروق الحديد علي العديد من الاواني الفخارية التي صور عليها الثعابين، فقد عثر على جرة

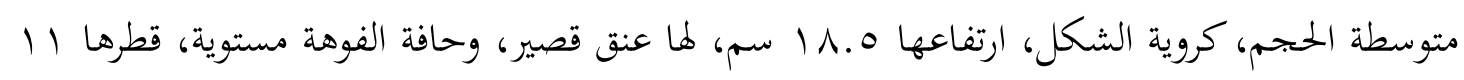

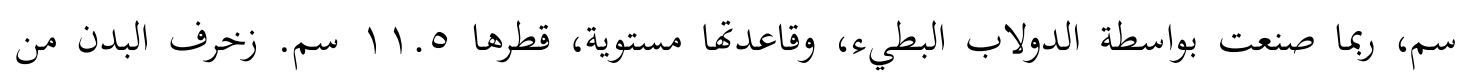
الأسفل بنطاقين نافرين بتحزيزات متقاطعة، وفي منتصف البدن أضيفت زخرفة قوامها خمس ثعابين نافرة بوضعية الزحف، رؤوسها مثلثة الشكل، وئ مقدمة الرأس شق عرضي يمثل الفم، والبدن مرقط بواسطة قصبة مفرغة، وأُضيفت على الكتف قريباً من العنق زخرفة ثعبانين تشبهان الثعابين الأخرى، إلا أن رأسيهما أعرض وجميع الثعابين تتجه من اليسار إلى اليمين. (الشكل رقم ( ) (TV)

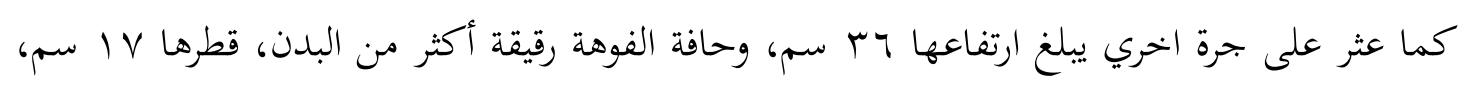
والقاعدة مستوية قطرها r r سم، تتكون زخرفة البدن من ثلاثة أطواق، أحدها يطوق البدن تحت 
العنق، واثنان يطوقان أسفل البدن متجاوران، جميعها زخرفت بتحزيزات غائرة ومتقاطعة. أُضيفت فوق الطوق العلوي على جابي الجرة زخرفة أفعيين، رأساهما على شكل مثلث، وزخرفة أربع أفاعٍ تحت الطوق الأول على منتصف البدن، وجميع الأفاعي على البدن مرقطة بواسطة قصبة مفرغة، وتتجه من ناحية

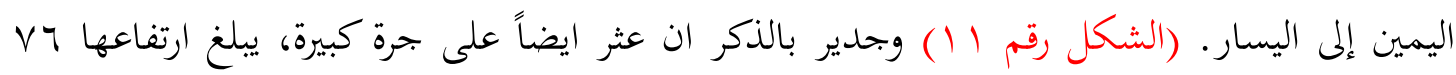
سم، وقطرها بr سم، والقاعدة مستوية دائرية قطرها وج سم، يُزين الجزء العلوي من النصف السفلي من الجرة أربعة أطواق مضافة، زُخرف البدن بأربع ثعابين زاحفة تتجه من اليسار إلى اليمين، رؤوسها بارزة على شكل قرنين، كما أضيف ثعبان يلتف حول أسفل الرقبة بشكل كامل، ويلتقي رأسها مع طرف ذيلها. زخرفت الأفاعي بواسطة قصبة مفرغة بثلاثة صفوف طويلة موزعة على البدن وجانبي

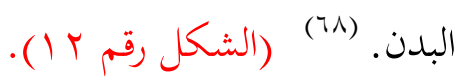

هذا بالإضافة إلى أن عُثر في ساروق الحديد أيضاً على جرة كبيرة، صنعت من عجينة ذات لون بني، يبلغ ارتفاع الجحرة .ج سم، وحافتها مستوية مشطوفة للخارج، قطر الحافة بr سم، والقاعدة مستوية دائرية قطرها \& ب سم، يزين منتصف البدن ثناثة أطواق، وأربع أفاع زاحفة تتجه من اليسار إلى اليمين، رؤوسها بارزة على شكل قرنين. زُخرفت الأفاعي بواسطة قصبة بشكل عشوائي موزعة على البدن

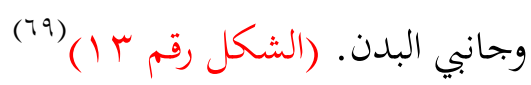

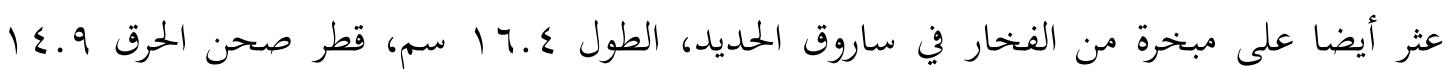
سم، وعمقه ه.0 سم، ويفصل بين الصحن والقاعدة حزام نافر يطوق البدن، الساق مفرغة من الداخل أسطوانية في جانبيها ثلاث فتحات بشكل طولي عرض الفتحة r.r سم، وطولها ه سم، ترتكز على

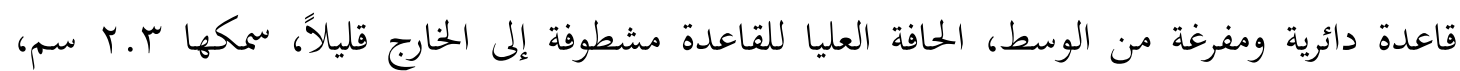

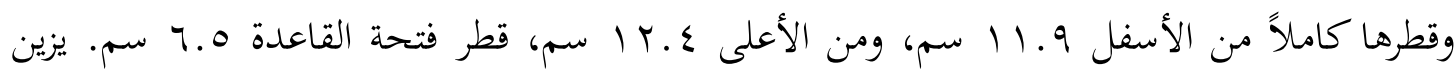

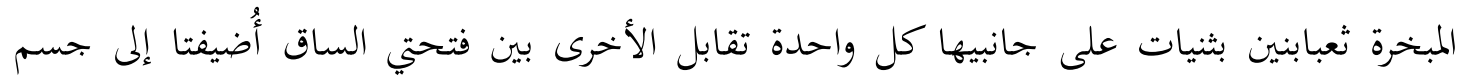
المبخرة ورقط بدنيهما بدوائر، جاء الذيل على طرف القاعدة والرأس على حافة الصحن يطل جزء منه داخل الصحن، رأس الثعبان مثلث الشكل وطولها اب سم. صنعت المبخرة باليد، ويبدو أن الصحن

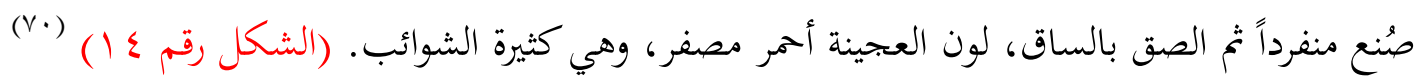




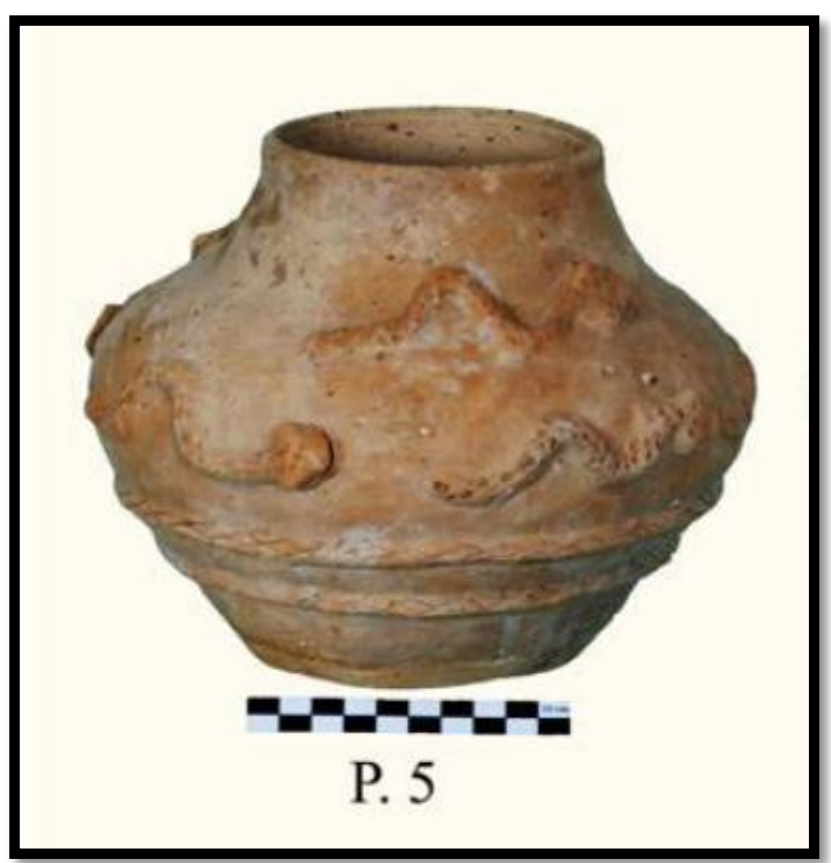

(الشكل رقم • () آنية من الفخار في موقع ساروق الحديد

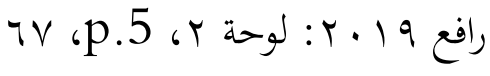

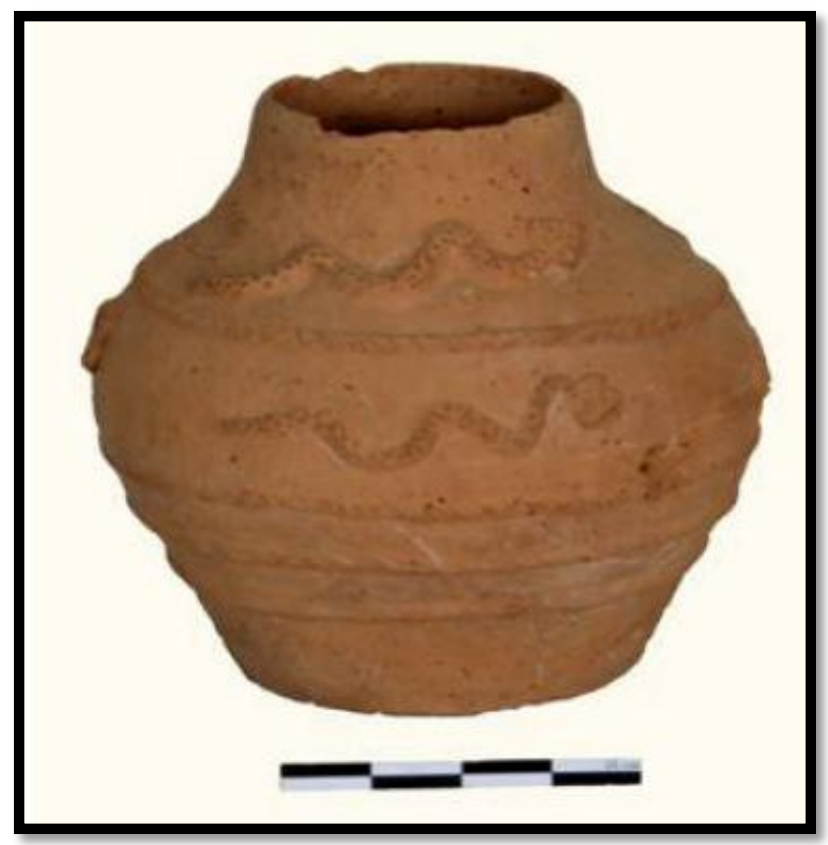

$$
\begin{aligned}
& \text { (الشكل رقم 11) آنية من الفخار في موقع ساروق الحديد }
\end{aligned}
$$

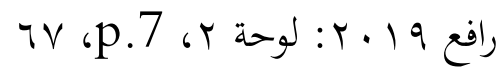




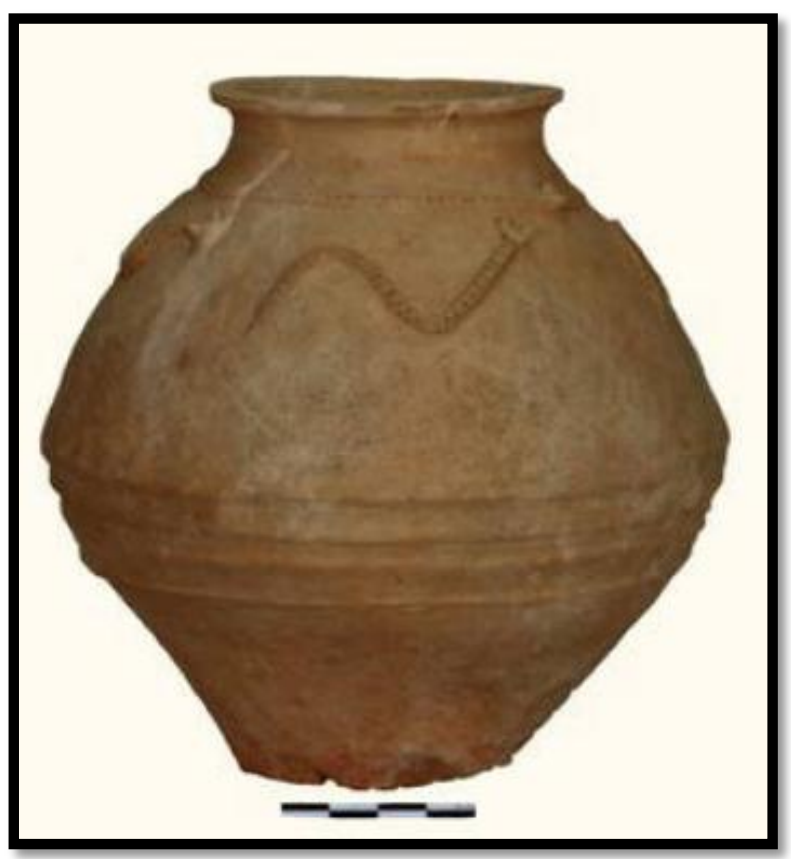

(الشكل رقم r I) آنية من الفخار في موقع ساروق الحديد

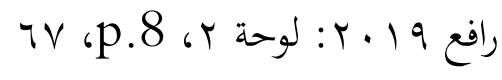

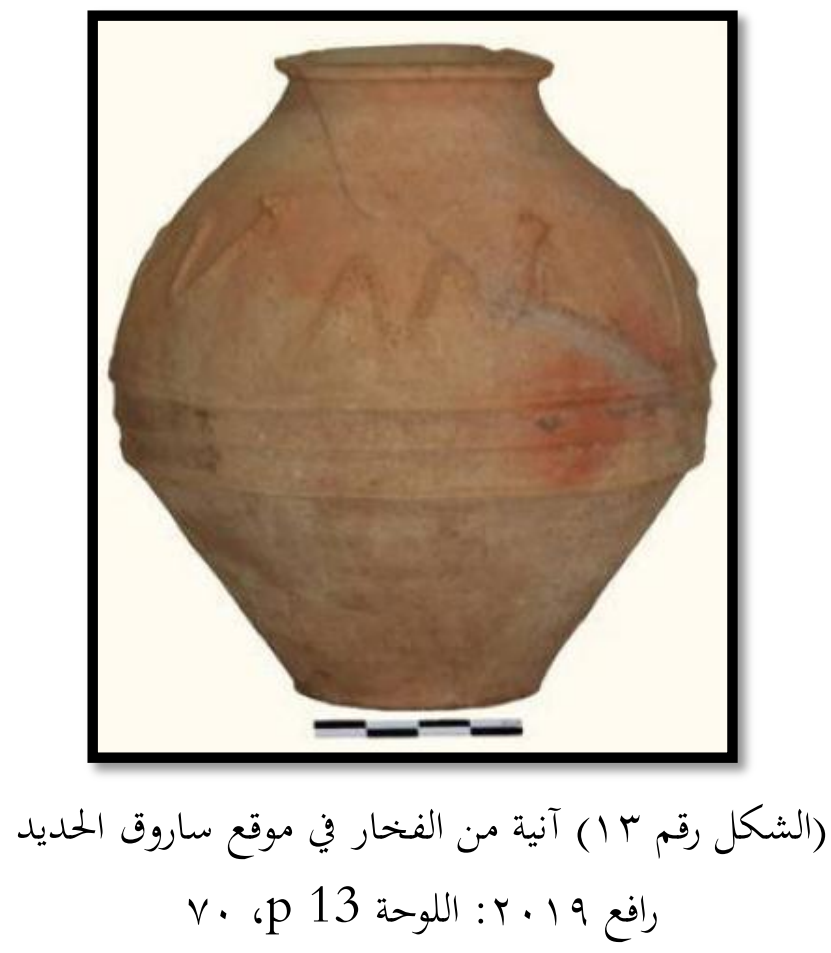




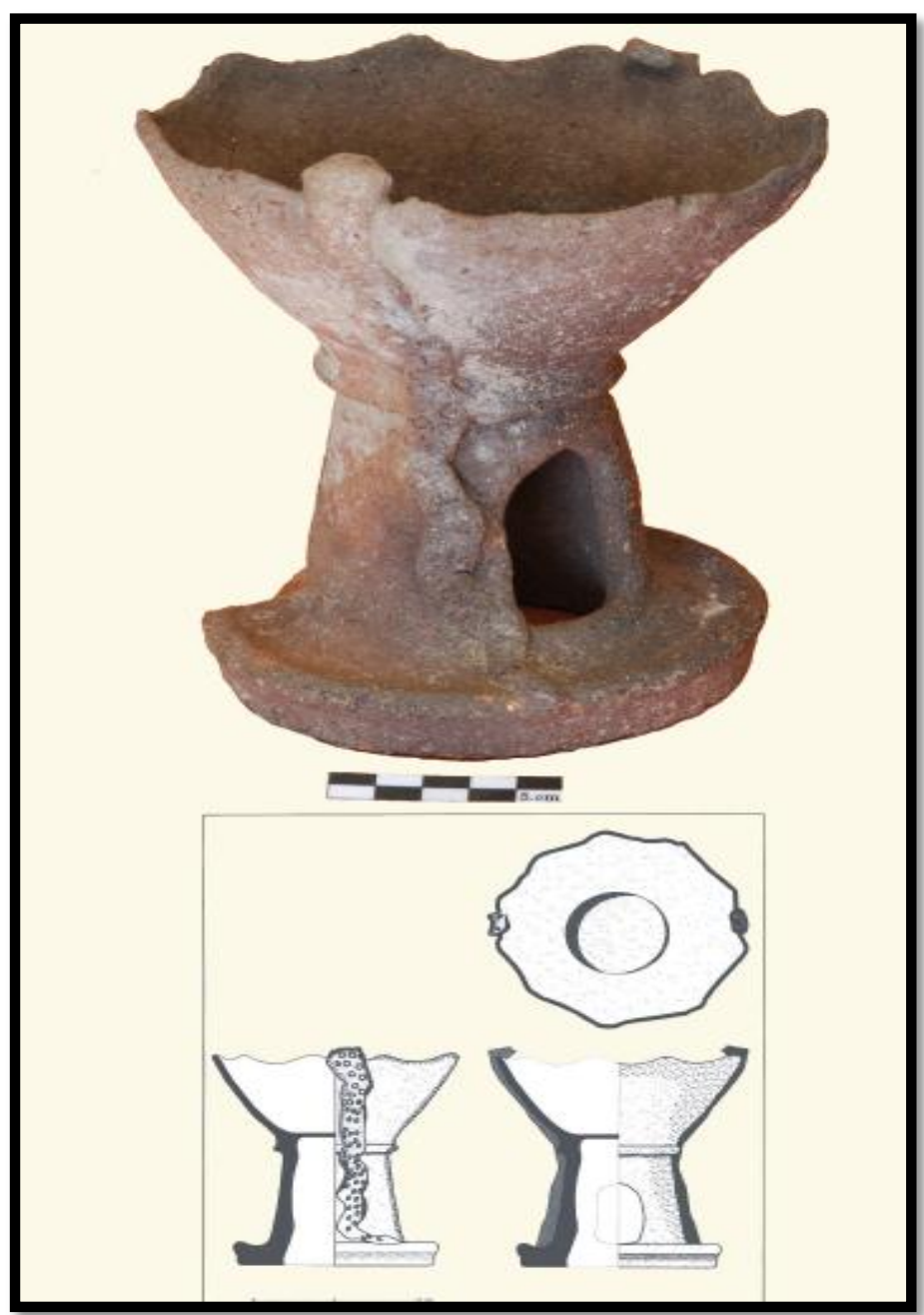

(الشكل رقم ع ( ) مبخرة فخارية من موقع ساروق الحديد بها تمثيل لثعبان

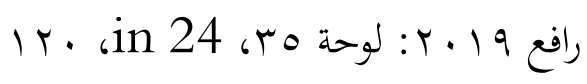

لم يقتصر الامر على تمثيل الثعابين على بدن الاواني والاوعية، ولكن ايضاً كان يتم تمثيلها على الأغطية، فقد عثر في ساروق الحديد على غطاء جرة خزين دائري قطره گr سم وسمكه r سم، المقبض نصف قوس عمل على شكل أفعى بسمك ب سه، وقد مُثل الرأس بإبراز قربي رأس الأفعى. ومثل الذيل ببروز صغير ملتو على السطح، وزُخرف السطح على جابي المقبض بإضافة أفعى على كل جانب، الرأسان متعاكسان ولكل منهما أربع ثنيات بطول V V سم، صنعت برتئ باليد، العجينة خشنة كثيرة الشوائب، اللون وردي رديئة الحرق. (الشكل رقم 0 (V) 


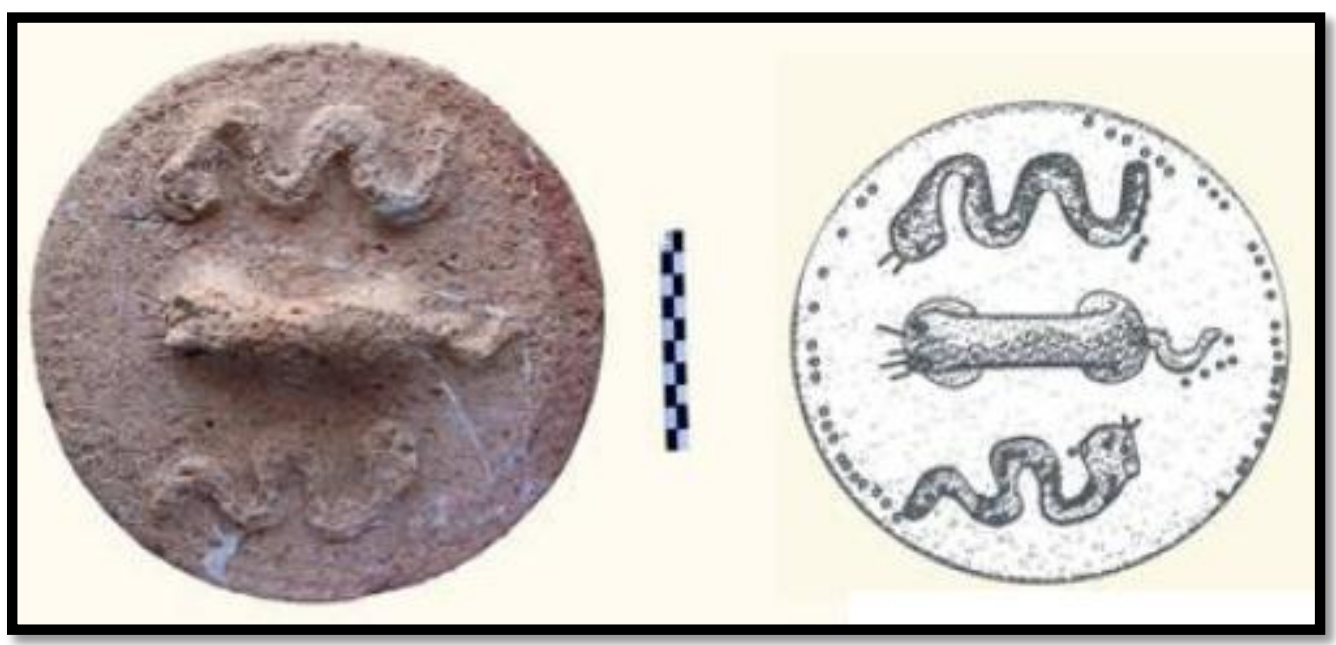

$$
\begin{aligned}
& \text { (الشكل رقم } 0 \text { 1) غطاء من موقع ساروق الحديد } \\
& \text { رافع } 19 \text { • } 19
\end{aligned}
$$

عثر في مواقع تعود الي العصر الحديدي على ثعابين برونزية (VI) فقد كُشف في موقع ساروق الحديد عن لقى أثرية عديدة من بينها الثعابين البرونزية المجسمة بأعداد كبيرة مما دفع بعض الباحثين لربط الثعبان بحرفة التعدين، وأنه كان الإله الحامي للعمال والحرفيين في ورشات التعدين والدلائل من موقع البثنه تدعم هذا الافتراض، فقد عثر على تلك النماذج بالقرب من المواقع التي كانت بتري فيها عمليات التعدين

الثعابين في ساروق الحديد كانت تصنع عن طريق الطرق أو الصب في قوالب تختلف أحجامها ما بين

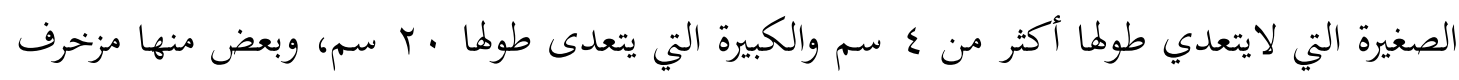
بداوئر صغيرة كتمثيل لجلد الثعبان، فنماذج الثعابين المكتشفة تشكل أنواع عديدة من الثعابين منها الكوبرا والفيبر والثعابين العادية التي كانت تعيش في البيئة القديمة للموقع، وربما كان سكان ساروق الحديد القدماء يصنعون تلك النماذج للاستخدام الشخصي عند إجراء طقوسهم الدينية أو أن البعض البض منها كان يصدر لخضارات أخرى.

$\left(^{72}\right)$ Taha, M.,Y., 1983: The Archaeology of the Arabian Gulf during the first Millennium B.C. Al Rafidan III-IV, P.75-87.

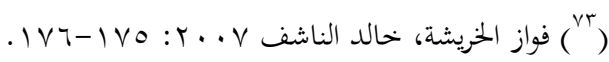
$\left({ }^{74}\right)$

الموقع الرسمي الالكتروني لمتحف ساروق الحديد https://www.facebook.com/\%D9\%85\%D8\%AA\%D8\%AD\%D9\%81\%D8\%B3\%D8\%A7\%D8\%B1\%D9\%88\%D9\%82\%D8\%A7\%D9\%84\%D8\%AD\%D8\%AF\%D9\%8A\%D8\%AF-115668936495560/ 
جدير بالإشارة الى ان عثر في ساروق الحديد على خنجر من الحناجر الفريدة والمميزة (الشكل رقم 7 (1)، صنع النصل من الحديد والمقبض من البرونز، طول النصل V.r إ سم، وعرضه ه.ب سم، وقد ظهر النصل سميكاً بسبب تأكسد الحديد وتكون الصدى عليه، أما المقبض مزخرف، تتكون فهاية المقبض من قرصين منفصلين عن بعضهما من الطرف الأمامي ومتباعدين ويلتقيان من جهة المقبض، كل قرص زُخرف سطحه الخارجي بأطواق تتكون من حبيبات وخطوط نافرة، وفي فاية كل قرص من الوسط رأس أفعى وتنظر كل منهما إلى الأخرى، بعد القرصين بحوالي ا سم تقريباً توجد حلقة اسطوانية حول المقبض الأسطواني، ثم يليها جزء من المقبض بطول و سم زخرف بسنابل طولية تحيط به، ويفصل بين خطوط السنابل وباقي زخرفة المقبض من جهة النصل حلقتان تحيطان بالمقبض، يليهما مباشرة جزء مزخرف بأشكال حلزونية أو لولبية مزدوجة، كل اثنتين متصلتين مع بعضهما البعض، وفي الوسط بروزان طوليان، وهذا الشكل يتكرر على وجه المقبض الآخر، كما يفصل المقبض عن النصل الحديدي حلقة (vo) بارزة. بلغ في موقع ساروق الحديد عدد الأفاعي البرونزية المجسمة المكتشفة حوالى rم ثعبان (الشكل رقم (IV)، شكلت بالطرق بمقطع مستطيل، وبشكل متعرج في وضعية الزحف، جاء رأس الأفعى على شكل

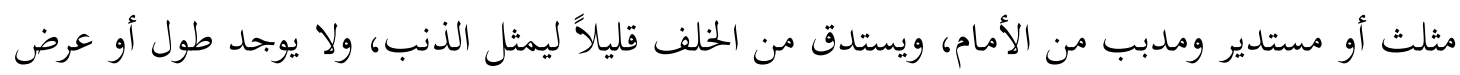
موحد لها وبعضها بالمستوى نفسه ما بين الرأس والذيل وبعضها يأتي الرأس مرتفعاً إلى أعلى وكأها

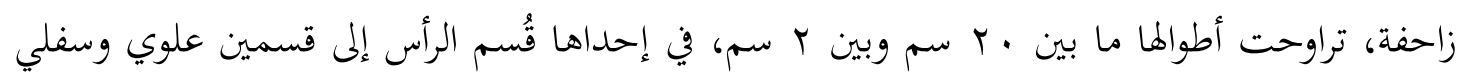
قصد منه التعبير عن فتحة فم الأفعى، لم يلحقها تلف بسبب حفظها في الرمال، وضعها بشكل عام جيد مع قليل من التأكسد، كما عثر على دلاية من البرونز على شكل أفعى ملتفة على بعضها (الشكل

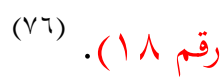




\begin{tabular}{|c|c|}
\hline د/سمر حماد فهيم & العدد الخامس والعشرين يونيو ا Y · Y م \\
\hline
\end{tabular}

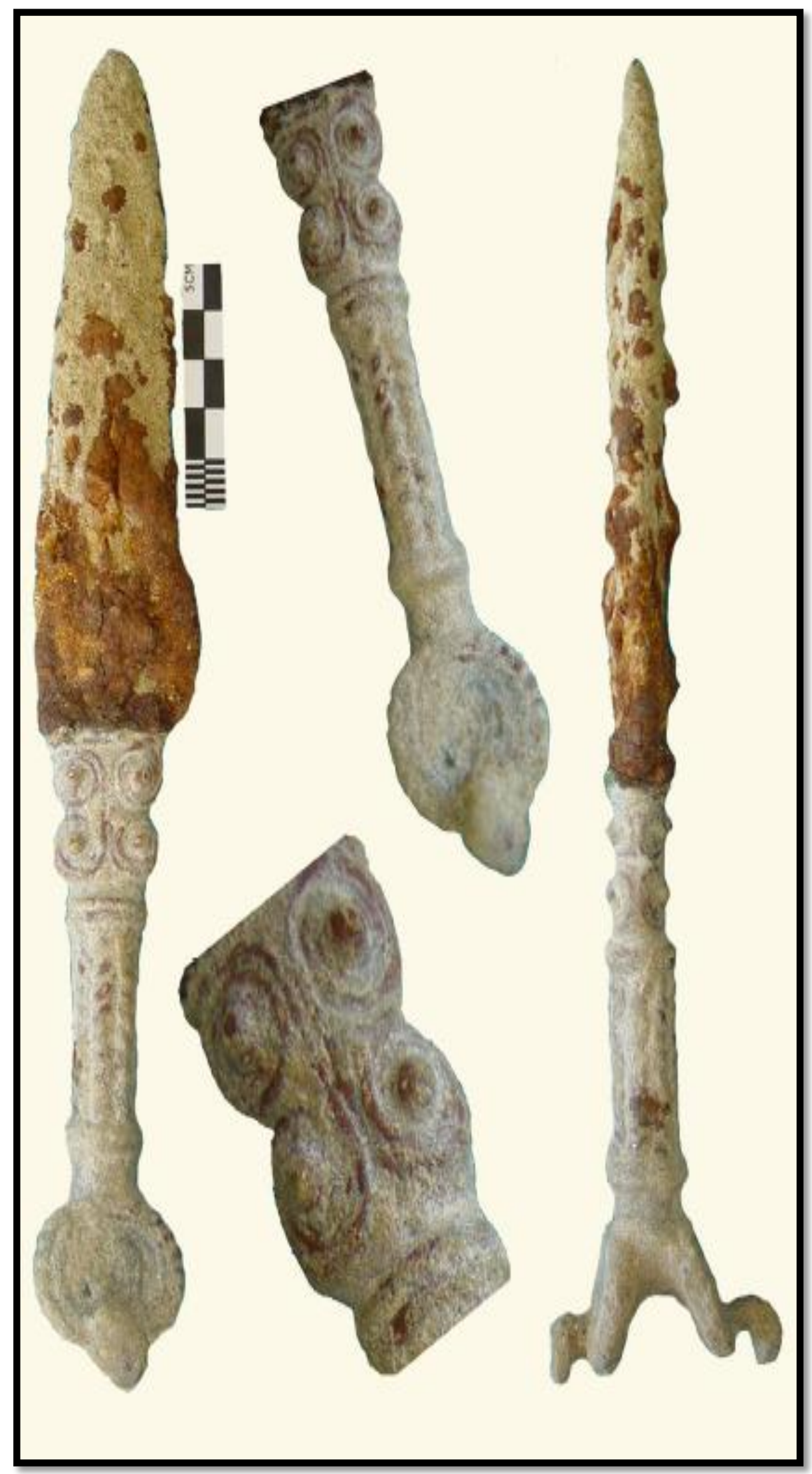

(الشكل رقم 7 (1) خنجر من موقع ساروق الحديد 


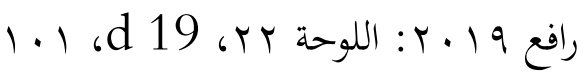

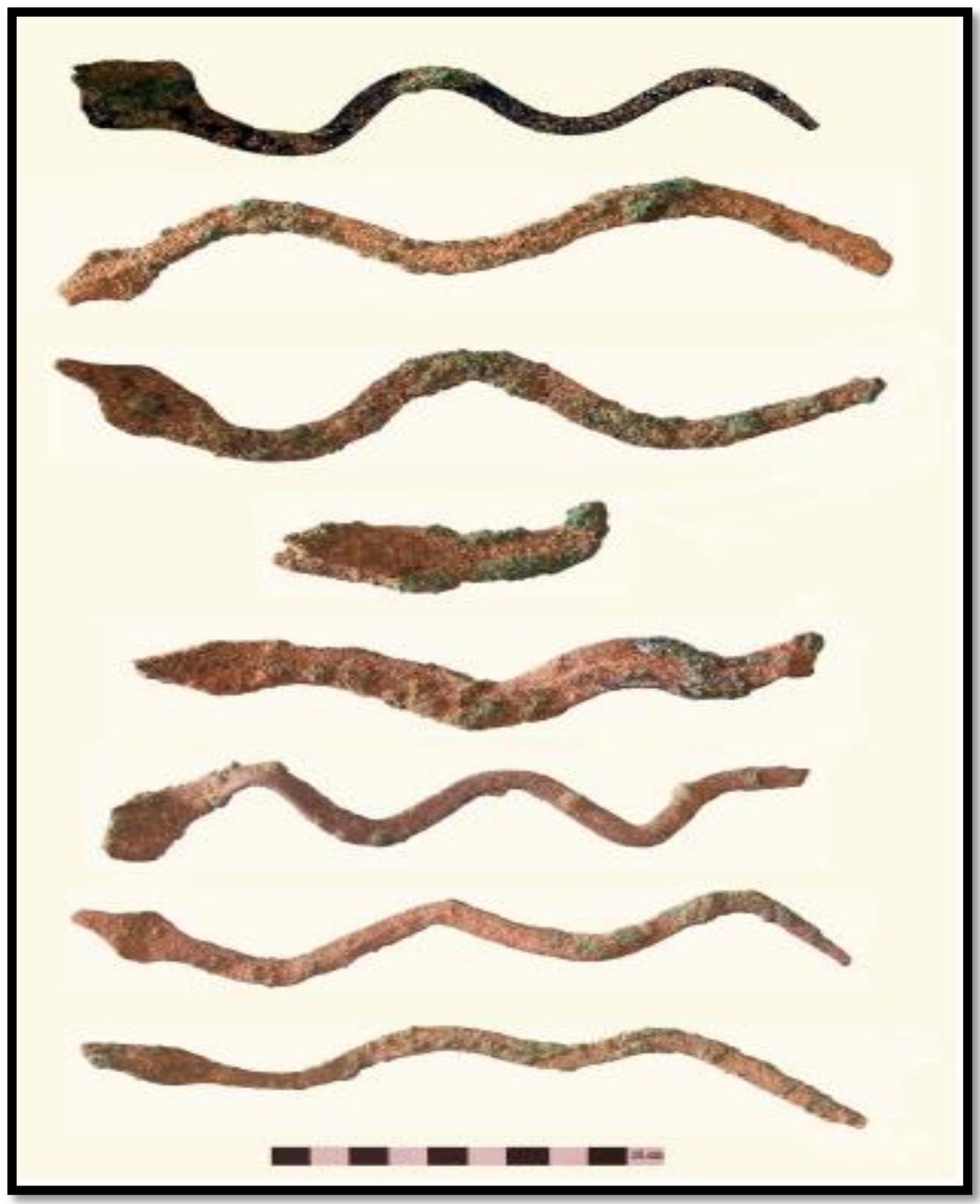

(الثكل رقم V بعض الثعابين البرونزية من موقع ساروق الحديد

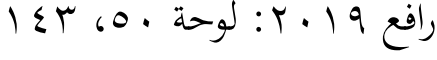

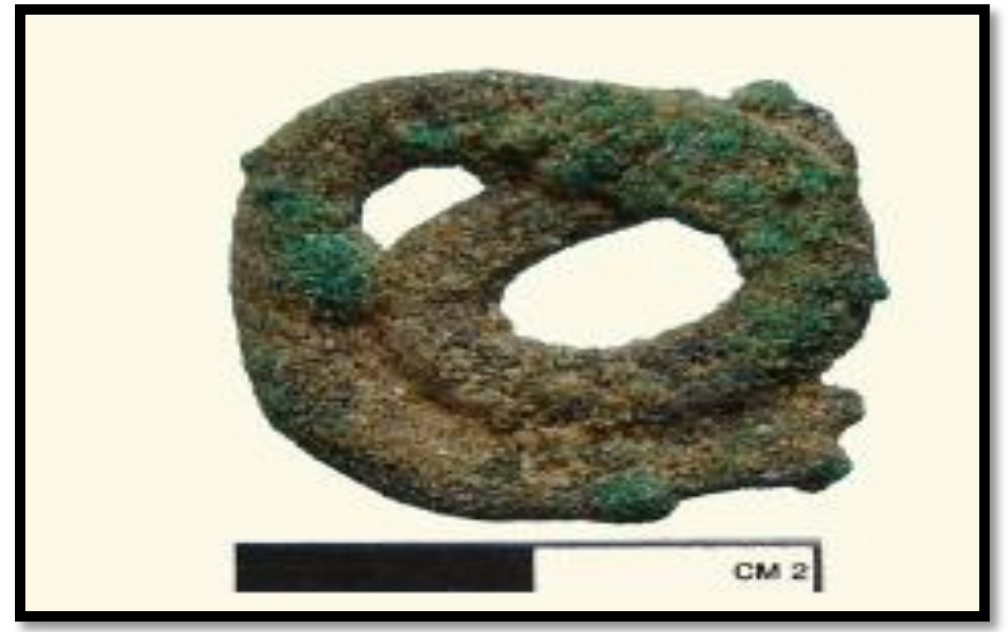

دلاية على شكل ثعبان من البرونز من موقع ساروق الحديد (الشكل رقم 11) 


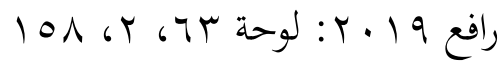

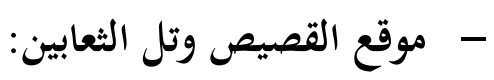

في منطقة القصيص عثر على تل سمي بتل الثعابين Mound Of Serpents وجود تماثيل الثعابين، مما يوحى إلى احتمالية وجود عبادة الثعبان ومعبد خاص به في ذلك الوقت خصوصا أن للثعبان أهمية كبيرة في حضارات أخري واحتمالية إقامة معبد خاص للثعبان في ذلك الوقت

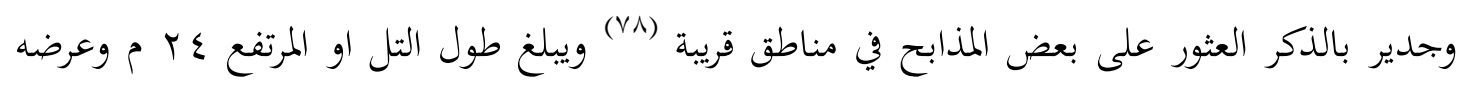

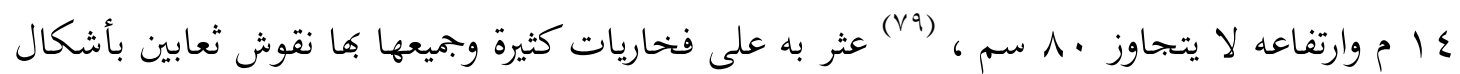
مختلفة ومطعمة (1.) تم الكشف أثناء التنقيب في هذا التل على بقايا جدران لفناء صغير يعتبر أساسه مشيد بالفروش والطين

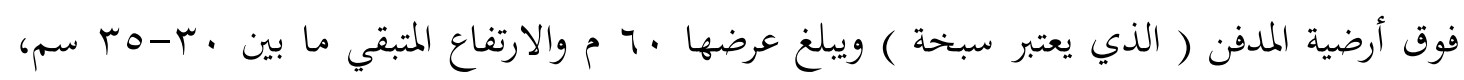

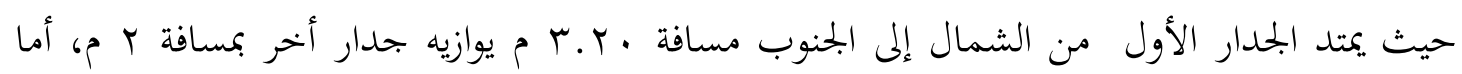
الجدار الثالث يمتد من الشرق إلى الغرب بمسافة ه.ب م ويرتبط بالجدارين من الناحية الجنوبية وبدون شك كان هذا البناء الصغير الذي كان في منتصف المستوطن رقم r بناء مهم ونظرا لوجود اللقى الأثرية التي تحمل الثعابين بكثرة فمن المحتمل أن يكون معبد صغير خصص لعبادة الثعبان وتقديسه وجدير بالذكر أن هناك أثار حرق على الجدران وبقايا رماد مما يدل على أن هذا البناء تعرض إلى الحريق.

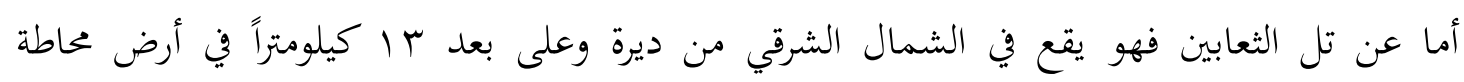
بالكثبان الرملية والشجيرات الصحراوية والأعشاب البرية. وفي منطقة تبلغ مساحتها حوالي ب كيلو متر مربع يوجد تل رملي عثر الباحثون الأثريون فيه على بقايا أثرية عبارة عن قطع من الخزف والحجارة

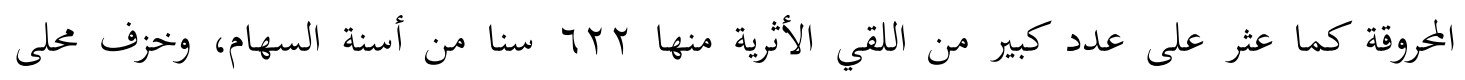
بزخارف تمثل ثعابين (رأسا ثعبانان لغطاء زبادية)، وتعابين أخرى برونزية صغيرة ومحارق بخور (مباخر

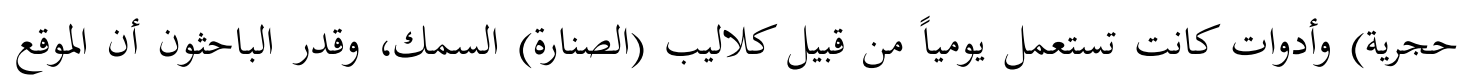
المذكور كان معبداً مقدساً وأنه كان للثعابين دور مهم في حياة الناس فأطلق عليه تل الثعابين، لقد قارن

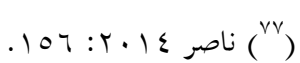

$\left(^{78}\right)$ Benoist, Anne, 2008: “The Iron Age Culture in the United Arab Emirates, between 1100B.C and 250B.C “ Bulletin of Archaeology, Kanazawa Univ. 29, P 36.

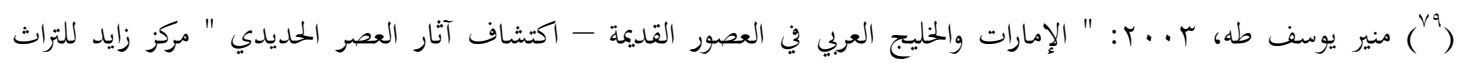

والتاريخ، ص

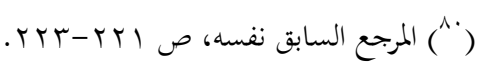

111 : 19V9 منير (1) 
الباحثون الأثريون بين الآثار المكتشفة في كل الثعابين وغيرها من الآثار فوجدوا أها كانت شائعة الاستعمال قبل مايزيد عن . . . س سنة. وتعد كل الثعابين الأثر الوحيد في منطقة القصيص الذي لم يكن على شكل مدفن أثري، والمرجح أنه كان معبداً صغيراً (AT) كما عثر أيضا في القصيص على ثعابين

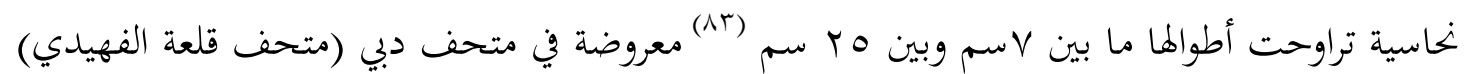

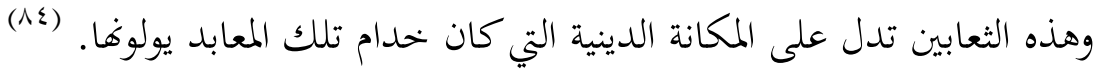
عثر على غطاء من الفخار وكاستين فخاريتين وبواقي فخار للحرتين متوسطتين لمما حافتين عريضتان مصنوعة على الدولاب لون الطينة من الأحمر إلى البرتقالي وبالطبع مطعمين بأشكال الثعابين ( الشكل رقم 9 ())، بالإضافة إلى إناء فخاري صغير ذات مصب وسطح الإناء خشن الملمس على سطحه الخارجي ثعبان بارز يمتد طوليا من الفوهة وحتى القاعدة تقريبا يقابله ثعبان بارز ملتوي آخر رأسه بارزة

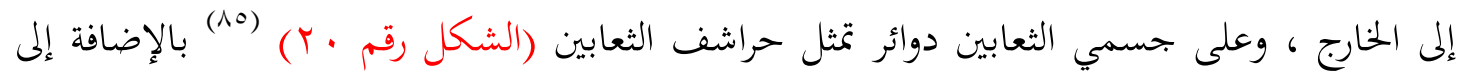
كسرات منها جزء من جرة كبيرة أو جزء من آنية متوسطة الحجم بها ثلاث ثعابين متداخلة وبقايا أواني مخصصة لحرق البخور وجزء علوي لجرة تخزين مع مقبض نصف دائري ، وأيضا عثر على كسرة كبيرة تعود إلى جرة تخزين كبيرة مصنوعة على دولاب بطينة برتقالية اللون مضاف إليها حجارة صغيرة وحول عنقها ثلاثة أطواق بارزة ومحلاة بحزوز تشبه سعف النخيل وبروز أشبه بشعاع يخرج من قرص قد يرمز إلى

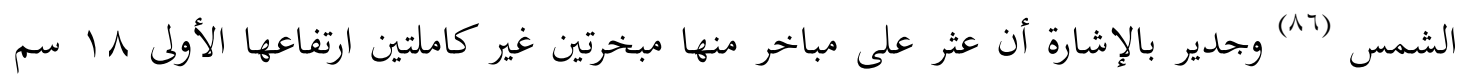
بقاعدة مستديرة و قطرها با سم وسط قاعدةًا عمود علية طوقا بارزاً ينتهي بإناء مخصص لحرق البخور والثانية اصغر حجما يبلغ ارتفاعها ب T سم وعثر على مبخرتين بهيئة كأسه لها مقبض طويل مصنوعين باليد من طينة حمراء اللون ، طول الأولى 10 سم وارتفاعها ع.1 سم على مقبضها ثعبان

( (ب) عزة بنت عبد الرحيم شاهين: عبادة الثعابين المعابد الأثرية في دبي (نموذجاً) خلال الألف الأول ق. م.، حولية الاتحاد العام للآثاريين

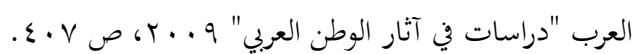
( $\left.{ }^{83}\right)$ Taha, M,.Y., 1983: The Archaeology of the Arabian Gulf during the first Millenium B.C. Al Rafidan III-IV, PP.75-87. Pl, 13.

(ع عزة بنت عبد الرحيم شاهين: عبادة الثعابين المعابد الأثرية في دبي (نموذجاً) حلال الألف الأول ق. م.، حولية الاتحاد العام للآثاريين

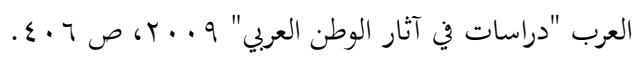

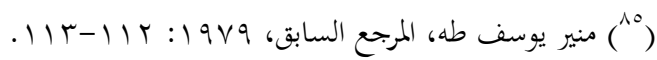

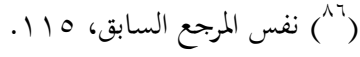


بارز مطعم بحجارة صغيرة والمبخرة الثانية فطولها 17 سم ، وارتفاعها 1.7 سم ومقبضها مزين بخطوط مخزة بزوايا.

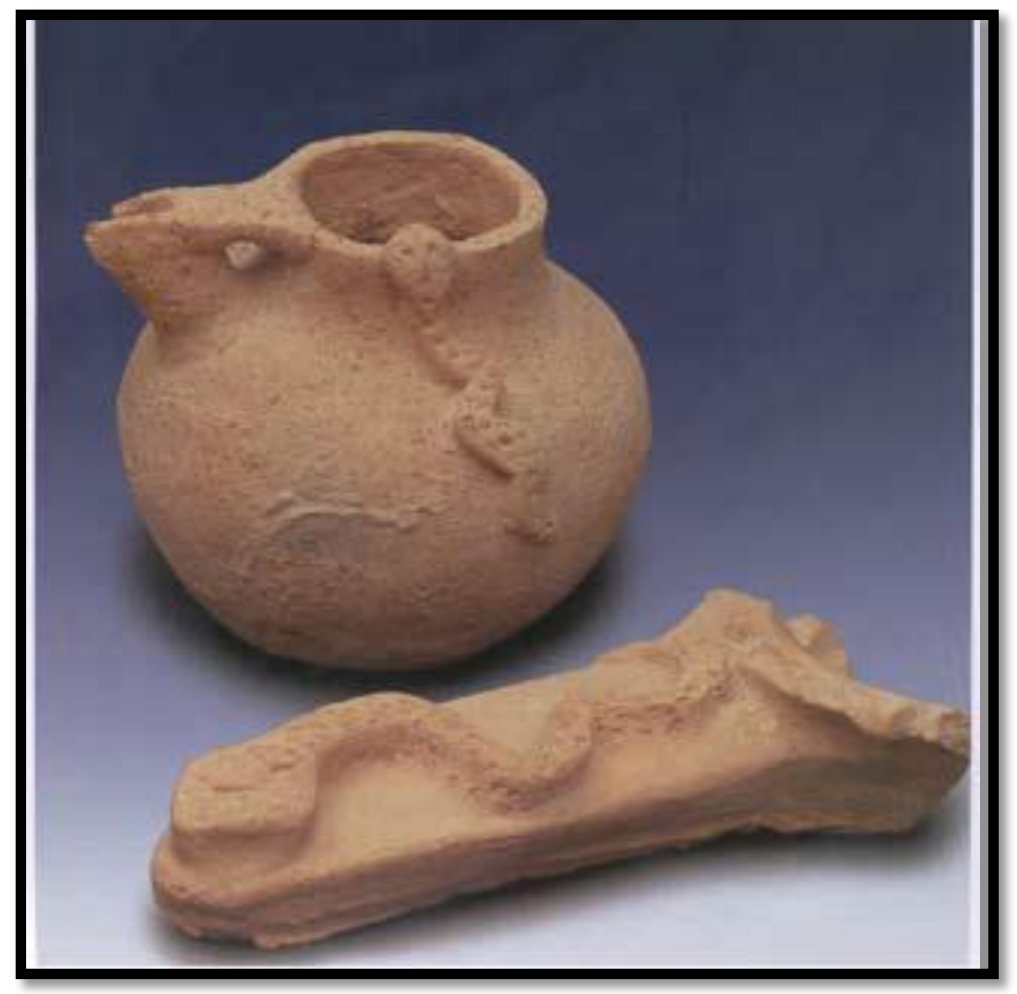

(الشكل رقم 9 ( ) آنية فخارية ويظهر عليها شكل الثعبان ويد أيضا عليها ثعبان

Potts 2003:316

فوجود هذا المبنى الذي يحتمل البعض أن يكون معبدا لتقديس الثعبان رغم أنه لا يوجد به ما يعبر أنه معبدا، فوجود رؤوس السهام بكثرة ينفى هذا الاحتمال هذا إلى أنه ربما كان مكان لتخزين احتياجات المستوطنة، ولكن يرى الباحث انه ربما كان معبدا وفى بعض الفترات الحروب والنزاعات فيما بعد استخدم كمخزن للأسلحة، ويري الباحث أن وجود الثعابين واهتمامهم بها ووضعها في كل مكان لا يدع بحال للشك انه أثر في نفوسهم ووصل مرحلة كبيرة يمكن أن تكون مرحلة التقديس خصوصا أن الثعبان تم تقديسه في العديد من الحضارات السابقة.

( $\left.{ }^{87}\right)$ Taha, M., Y., 2009: “ The Discovery Of The Iron Age In The United Arab Emirates “ First Edition, Ministry Of Culture ,Youth And Community Development ,U.A.E, P.93-94. 
إضافة إلى ما تقدم فقد تم العثور على دلاية من الرصاص وخمسة رؤوس سهام حديدية فوجود الحديد هنا في المكان يدل على انه يعود إلى بداية العصر الحديدي.(^) ليس فقط كان هناك مكتشفات أثنرية تخص الثعبان في المناطق سالفة الذكر بل كان هناك مناطق عديدة بدولة الإمارات العربية المتحدة بها بعض الآثار التي تشير إلى وجود الثعبان من بين مكتشفاقا وهذا اكبر دليل على أن الثعبان كان له دور فعال خحلال فترات ما قبل التاريخ وبالأخص العصر الحديدي فقد وجد الثعبان من خلال أثنار حجرية أو فخارية أو نحاسية أو برونزية في العديد من الأماكن منها مسافن بالفجيرة (الشكل رقم اY ) والثقيبة

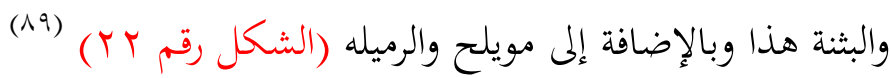
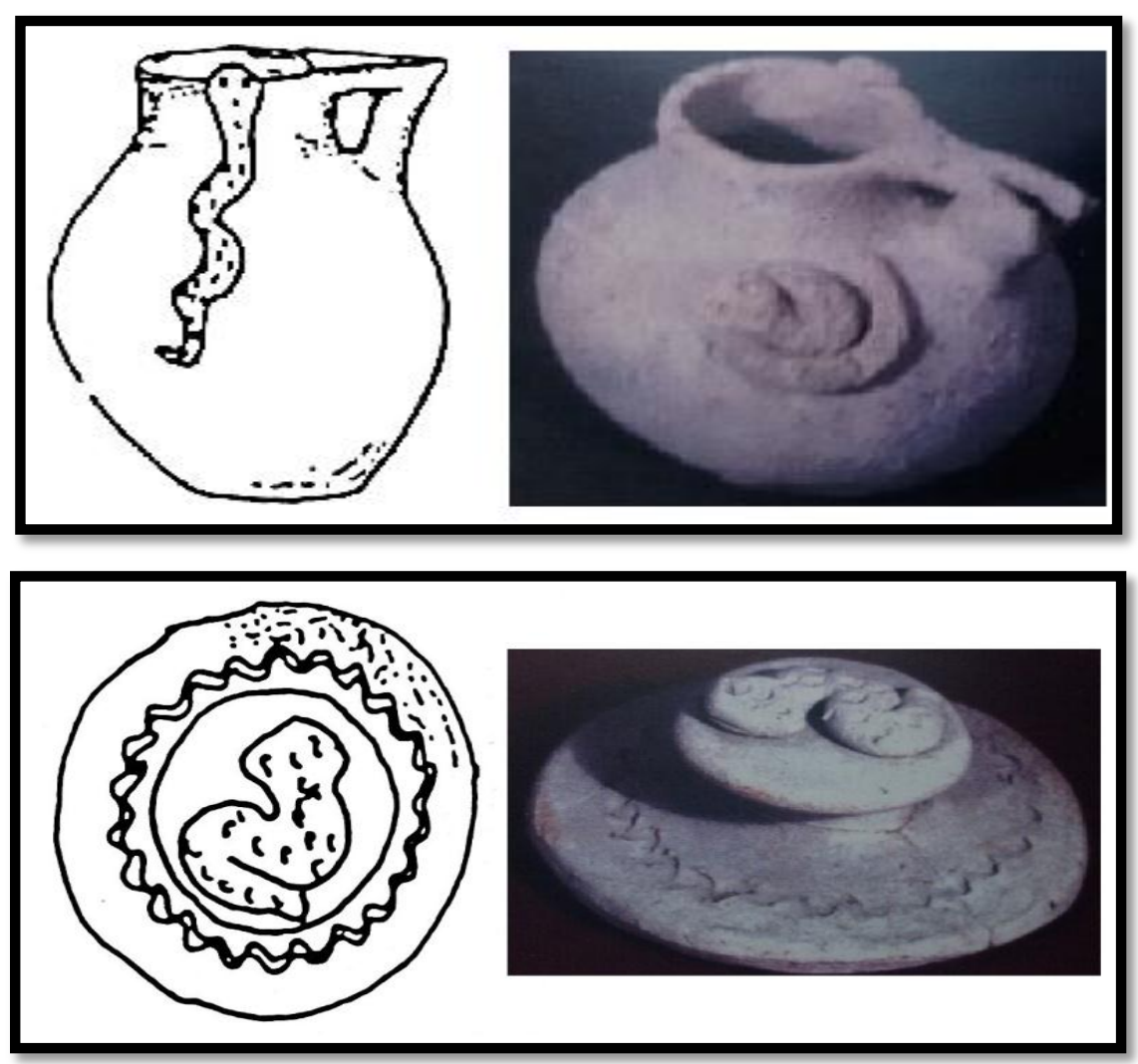

(الشكل رقم · (Y) غطاء فخاري على مقبضه ثعبان يمكن أن يكون مطعم جسمه بأحجار للدلالة على

$$
\begin{aligned}
& \text { الحراشف وزخرفة تدل على رمز الثعبان أيضا، تل الثعابين }
\end{aligned}
$$

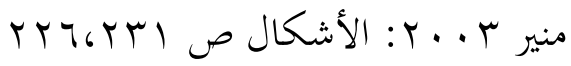

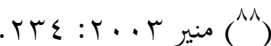

( $\left.{ }^{89}\right)$ Mouton, M., Benoist, A., Cordoba, J., 2011:" The Snake Figuration In Iron Age” Journal Of The National Center For Documentation \& Research, LIWA, VOL. 3 ,UAE, p. 9-15. 


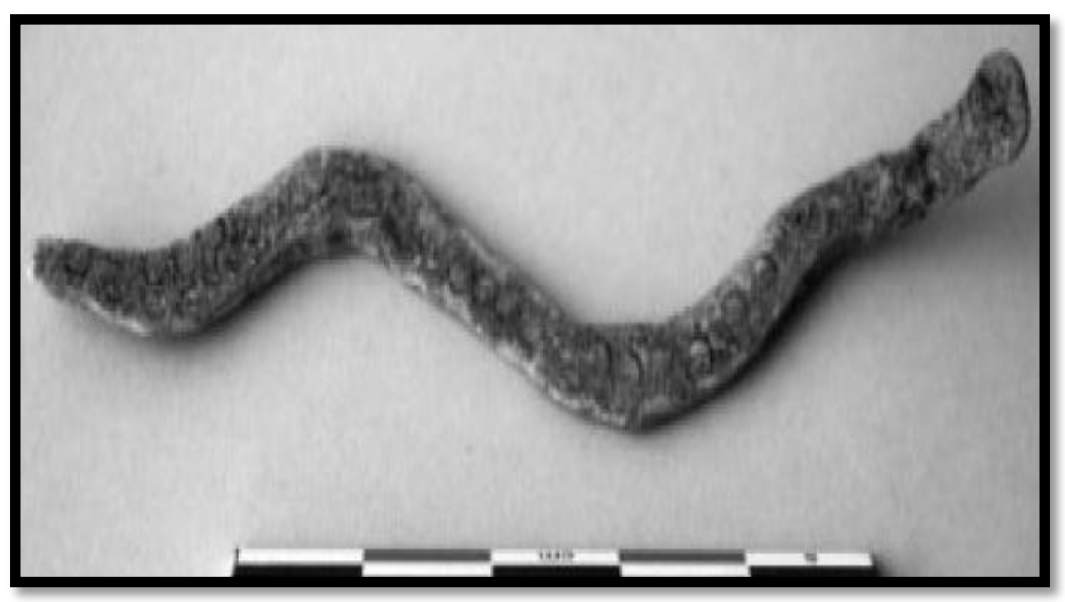

$$
\begin{aligned}
& \text { (الشكل رقم اYY) ثعبان } \\
& \text { من النحاس مزين بدوائر } \\
& \text { صغيرة ، مسافى -" }
\end{aligned}
$$

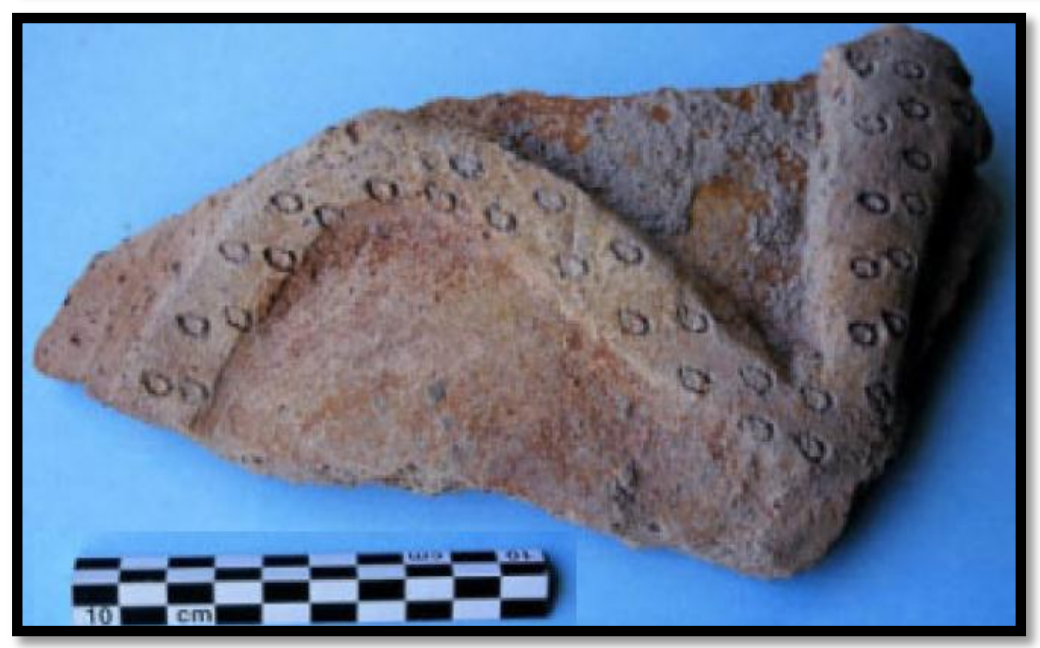

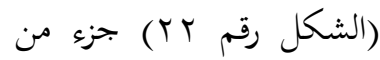

فخار منقوش علية ثنبان البثنة

\section{Mouton 2011: Fig. 3-5 p.5-6}

تم العثور على فخاريات في الرميله من أفضل النماذج التي تعود إلى العصر الحديدي، حيث ظهر في إحدى الأواني ثعبان ملتفة حول نفسها على بدن الفخارية ومن المحتمل أن يكون لرمز الثعبان علاقة

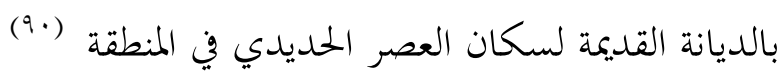
منطقة البثنة تقع في وادي حام على سهل صغير تحفة الجبال والمرتفعات ينحدر الوادي من منطقة مسافي

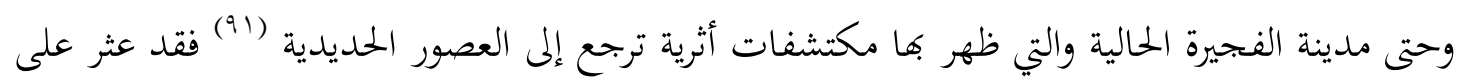
بقايا معبد عبارة عن مبنى مستطيل أبعاده ب X Y X أمتار حيث المساحة الإجمالية للمكان الذي

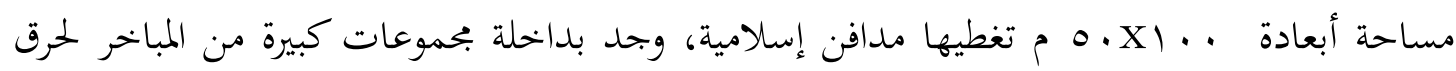
البخور والأواني الفخارية عليها رسوم تمثل الثعابين وتم العثور أيضا على مذبح تقديم القرابين ولذا صنف

$\left({ }^{90}\right)$ Frifelt , Karen, 1975: “A Possible Link Between the Jemdet Nasr and the Umm An-Nar Graves of Oman “ J.O.S., P 170-172. 
على انه ربما كان معبد وذا مركز ثقافي هام في ذلك الوقت، حيث يعتبر من اكبر المعابد التي ترجع إلى العصر الحديدي في المنطقة.

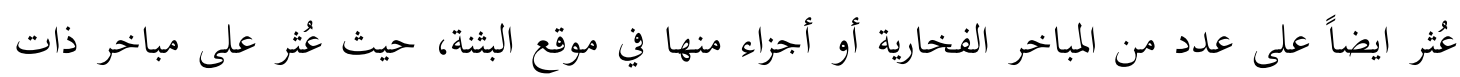

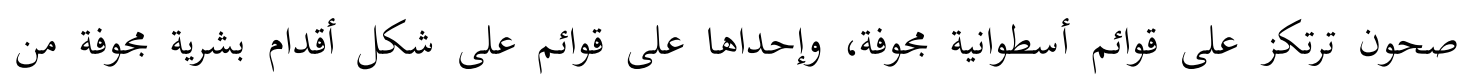

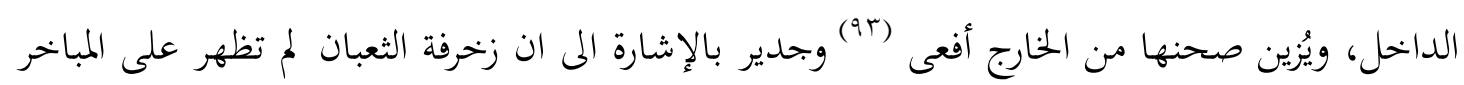

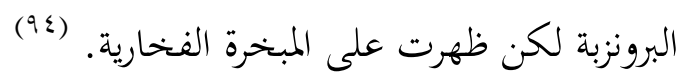
تضم منطقة مسافي بالفجيرة أربعة مواقع أثرية رئيسية تم اكتشافها على مراحل زمنية متتالية وتم البحث

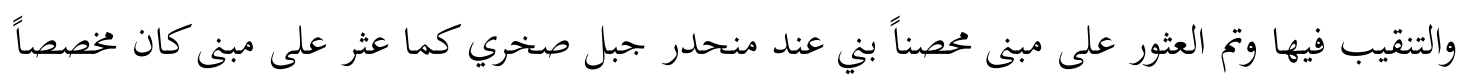

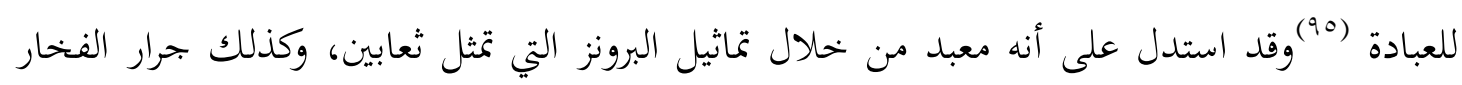

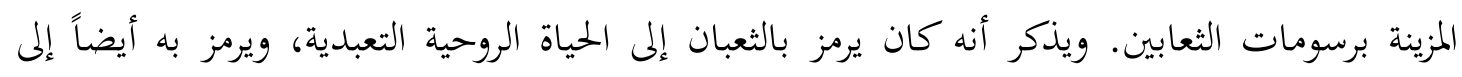

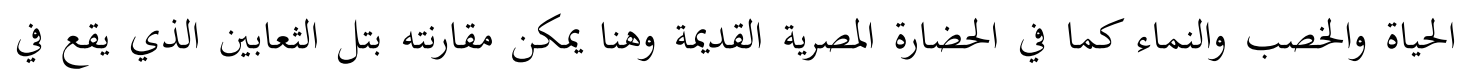

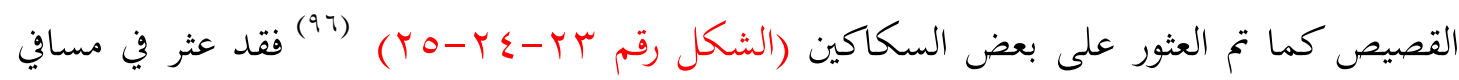

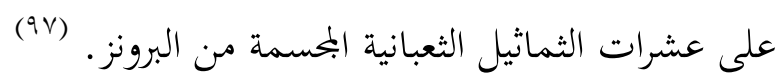
عثر الدكتور "دانيال بوتس" وفريقه على كسر فخارية بمنطقة تل الابرق تعود إلى العصر الحديدي والتي

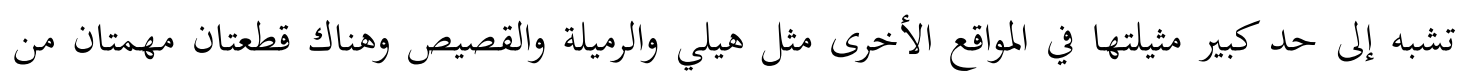

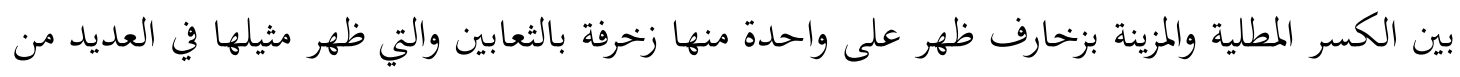

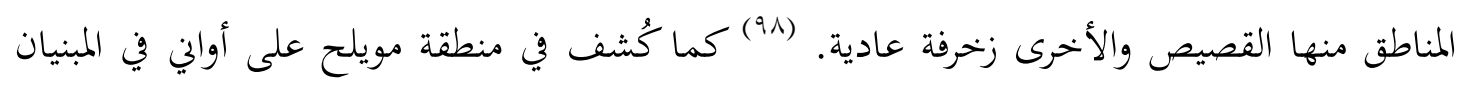

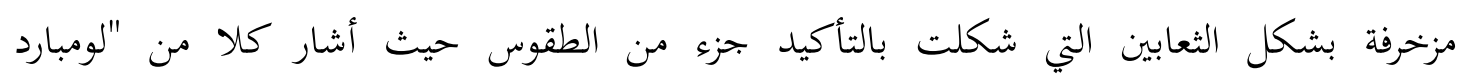

$\left(^{92}\right)$ Benoist, A., 2005: “ fifth archaeological campaign at Bithna " Preliminary Report, Fujairah, French Mission In U.A.E, P.7.

$\left(^{93}\right)$ Benoist, A., 2010: Authority and Religion in South East Arabia during the Iron Age: A Review of Architecture and Material from Columned Halls and Cultic Sites، Eastern Arabia in the First Millennium BC. Arabia Antica 6. Edited by Alessandra Avanzini, 2010, Roma. P.121.

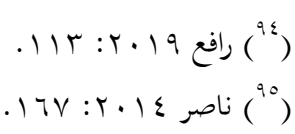

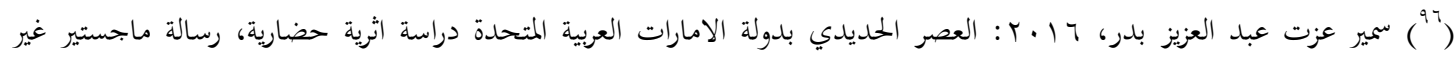

(7) Taha, 1983: 75-87. Pl, 13.

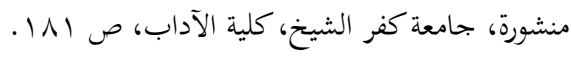

(98) Potts, D., T., 1991: “ Further Excavations At Tell Abraq “ The 1990 Season, Copenhagen, Munskgeerd,P.84. 
وبوشارلات" إلى الأهمية الرمزية للثعبان في حضارات الشرق الأدنى القديم وحتى الحضارات المصرية القديمة

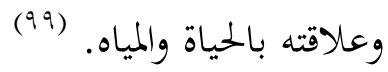
قدمت العديد من المواقع الأثرية في سلطنة عمان على دلائل لوجود الثعبان في عصور ما قبل التاريخ حتى وان كان اغلب هذه المواقع لم تقدم الكثير من الدلائل الأثرية، حيث أن اغلب المواقع قدمت دليلاً واحداً على الأكثر، فقد تم احصاء المواقع التي عثر بها على الدلائل الأثرية للثعبان الم حوالي با موقع أثرى في سلطنه عمان. (1..) عثر في قرية سنت (1.1) على بقايا لنقش ثعبان وذلك عند اجراء مسح لاحد المواقع التي عثر بها على مدافن ترجع الى عصور ما قبل التاريخ، وكانت بحاله سيئة وذلك لوجود بعض الاعمال الخاصة بالإنشاءات الحديثة التي اثرت على موقع الحفر ولكن تم تحميع تلك القطعة وللحفاظ عليها، هذا بالإضافة إلى العثور على حجر جيري نقشه على أحد أوجه ثعبان بالنحت البارز يأخذ اللون الرمادي الباهت، وكان هذا الحجر هو جزء من قبور ترجع إلى فتره أم النار. (r.1)

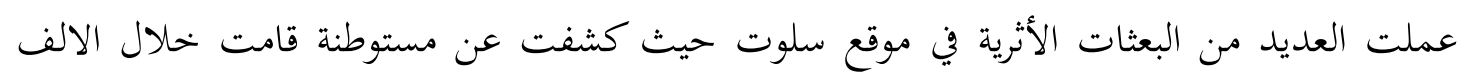
الثالث قبل الميلاد، وقد عثر على عدد من الأواني المزينة بالتصاوير للثعابين، فربما كانت عباده الثعابين تقام في تلك المنطقة، كما كشف التنقيب ان تلك المنطقة قد قامت بطقوس دينيه والمتمثلة في عباده الثعابين وذلك من خلال العثور علي كسر فخارية مزينة بزخارف الثعابين وكذلك ثعابين بحسمة من

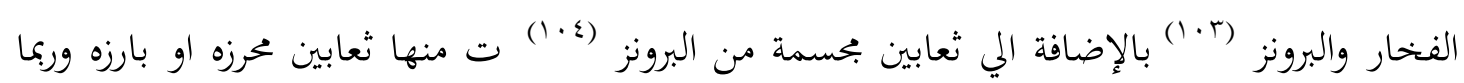
كانت الأواني مباخر أو قناديل وذلك للعثور على اثار حريق بها، كما عُثر على راس افعى مصنوع من إنى

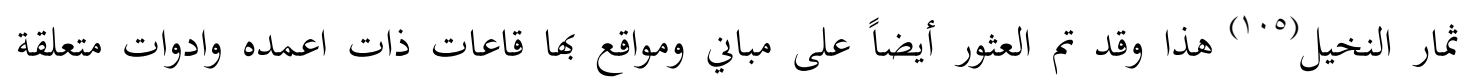
بتقديم النذور كثعابين برونزية وفأس صغيره وحلى شخصيه. (T-1)

$\left({ }^{99}\right)$ Benoist, 2005: 7.

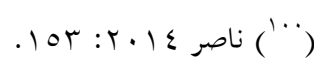

$$
\begin{aligned}
& \text { (' (') قرية سنت هي إحدى القري الجبلية التابعة لولاية بُهلا في محافظة الداخلية. }
\end{aligned}
$$

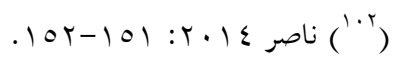$$
{ }^{103} \text { Benoist, 2010: } 121 .
$$

$\left({ }^{104}\right)$ Avanzini, A., \& Phillips, C., 2010: An Outline of Recent Discoveries at Salut in the Sultanate of Oman. Eastern Arabia, in the First Millennium BC. Arabia Antica 6. Edited by Alessandra Avanzini. Roma, p.10.

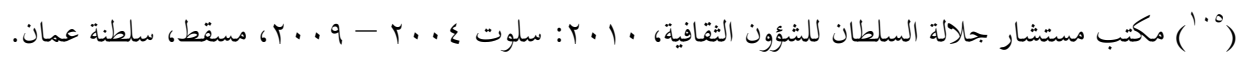
( $\left.{ }^{106}\right)$ Salut, Sultanate of Oman, report (2009-2005), p.373. 


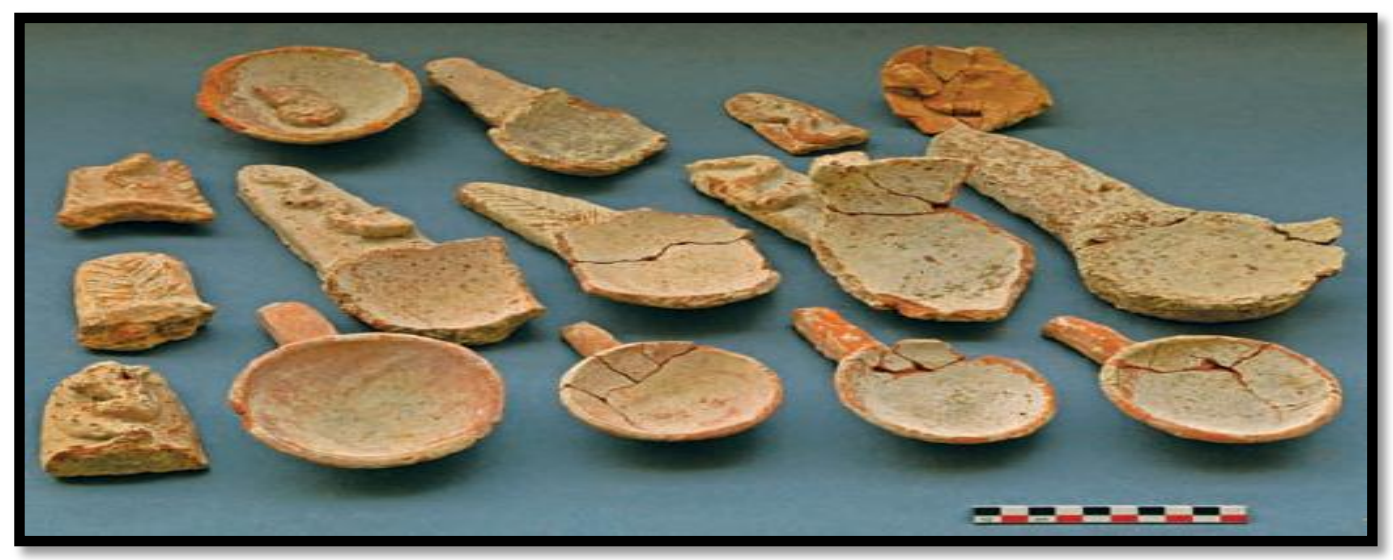

(الشكل رقم r أواني فخارية ذات مقبض طويل ومنها مزخرف بالثعابين، مسافن

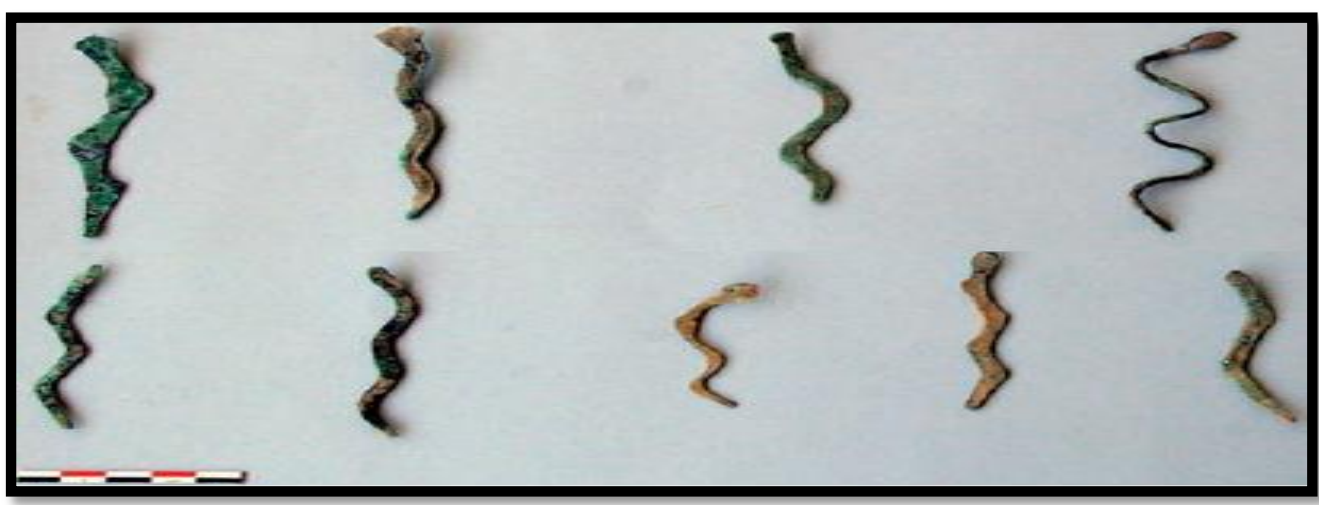

(الشكل رقم £؟) ت ثعابين من النحاس من مسافن

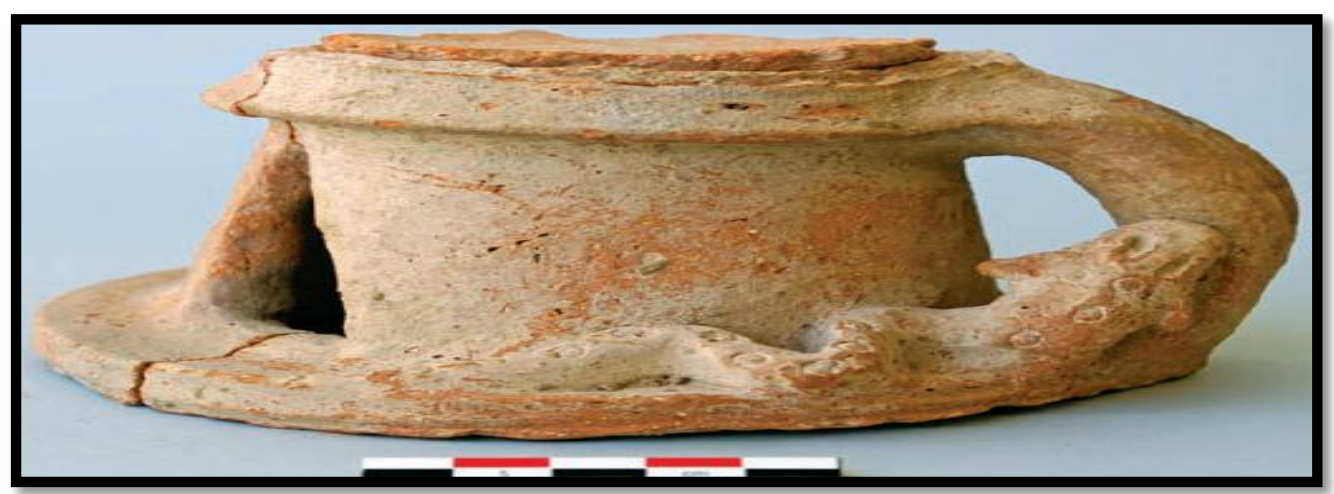

(الشكل رقم ه广) عنق مزهرية بيد وفتحة جانبية ويظهر زخرفة ثعبان علية، مسافى

تشير تماثيل الثعابين على الجرار الفخارية الكبيرة والصغيرة وأغطيتها، إلى أنه كان للثعبان في شرق الجزيرة العربية قدسية، وأها كانت تتمتع بقوى سحرية على أفراد المحتمع، فهي رمز للحياة ورمز لقوى الخصوبة، تجحد حياما بتغيير جلدها، وهي قاتلة من جهة وواهبة الحياة من جهة أخرى، ومن المحتمل أنه كانت تقام طقوس في المعابد، من شعائرها تقديم تماثيلها البرونزيه، والأواني التي تحمل زخارفها، كهدايا نذرية 
للإله، أو توضع كمرفقات جنائزية في المدافن مع المتوفين، ومن ضمن هذه الممارسة كانوا يعتقدون أهم يتصلون مع الآلهة التي يؤمنون بها بواسطه الثعابين، وبالتالي فهي قادرة بالنيابة عن الآلهة على منح الخصوبة للإنسان، والخصب والنماء للمزروعات، وهي واهبة الصحة والمرض، والحياه والموت، والخوف والأمان، وهي الحامية من كل الشرور والقاتلة بلدغتها في نفس الوقت. (V.) هناك العديد من المواقع التي قدمت دلائل كثيره برزت اهمية الثعبان في شرق الجزيرة العربية وبالأخص في حضارة بحان، فهذه المواقع قدمت دلائل متنوعة تشير بوضوح اهميه الثعبان التي ربما ارتقت الى العبادة(1) (1) (1)

وجود زخارف ثعابين على الاواني في العديد من المواقع يعني اها ربما استخدمت هذه الأواني في المعابد، وقد يُفسر وجود زخرفة الثعابين على جرار التخزين كنوع من الممارسة السحرية لحماية محتويات الجرار من

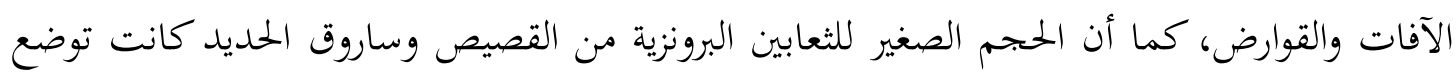
بالدرجة الأولى في الجرار وبين الحبوب لغرض الحماية وربما أيضاً في مخازن المحاصيل الزراعية. (9.1) رابعاً: الثعبان في دلمون: بادي ذي بدء بحب الإشارة الى أن الدراسات التي قامت على الفكر الديني في شبة الجزيرة العربية قليلة فقد عثر على دلائل موجودة للثعابين واهميتها في دلمون، فقد كان هناك قدسية للثعبان في تلك المنطقة من خلال المدافن التي تم العثور عليها في بحمع مبني من دلمون المتأخرة في قلعة البحرين والتي من خلالها

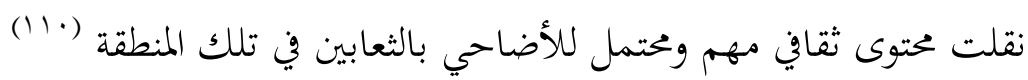
عثر على العديد من الهياكل العظمية لثعابين في العديد من الغرف المتواجدة داخل مبني قلعة البحرين وهو عبارة عن بحمع من الوحدات المنزلية مختلفة الاحجام، فقد أحتوي المبنى على مناطق عامة وخحاصة ميزة، مفصولة بفناء مركزي، ويمتلك نظاماً صحياً، كما كشفت عن منارسة غريبة بها حيث تم وضع أكثر من خمسين ثعبان مذبوح في أوعية مخبأة تحت الأرضيات في عدة مناطق من القلعة. (111) فالثعابين المتواجدة عثر عليها داخل أواني فخارية وبقي منها الهياكل العظمية وفى بعض الأوقات تلك الأواني

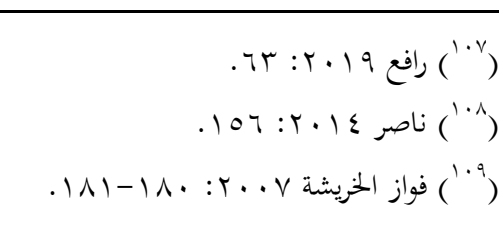

$\left({ }^{110}\right)$ Potts, 2007: 55-74.

ناصر 179 (111) Lombard, P., 2018: Qal'at al-Bahrain, Ancient Capital and Harbour of Dilmun. The Site Museum, a world heritage site, Bahrain Authority for Culture and Antiquities, p. 54 . 
كانت مغطاة بواسطة أواني أخري كانت تغلق الحفرة والأواني بالملاط، فقد عثر في بعض الدفنات على ثعبان دفن مع صدفة وفى أحياناً هناك دفنات اخري تم تغطيتها بالألبستر هذا بالإضافة إلى العثور على

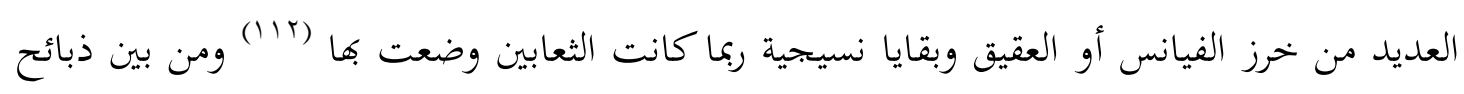
الثعابين، احتوت على كلا من العقيق والخزف، فمعظم هذه الأضاحي تحتوى على حرز ويبدو أنه يبرز

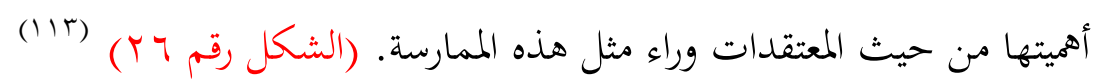
كما عثر على أواني أو ما يطلق عليها أحياناً باللغة المحلية زباديات ومغطاة بأغطية من نفس خحامة الزباديات الفخارية، وبالرغم من جهود علماء الآثار لمعرفة الهدف لوضع الثعبان بهذه الطريقة إلا أهم أشاروا إلى أن ربما كان الهدف من ذلك عبادة الثعابين وإذا صح هذا القول فيعتبر هذا الموقع أقدم موقع

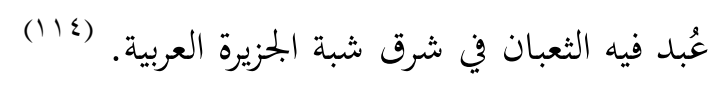

استخرجت البعثة الدنماركية العاملة في قلعة البحرين اثنان وثلاثون من الأضاحي التي تحتوي على هياكل

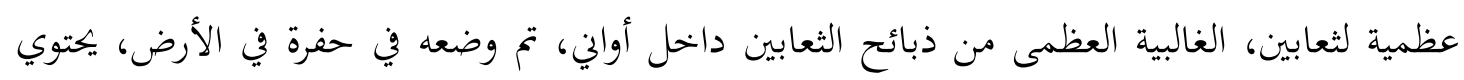
على هيكل عظمي لثعبان. في بعض الحالات، كان الوعاء الذي يحمل الثعبان مغطى كما ذُكر، وأحيانًا تم إغلاق الحفرة والإناء الخزين مع محتوياته بالجبس. في إحدى الحالات يبدو أن الثعابين دفنت في اوعيه

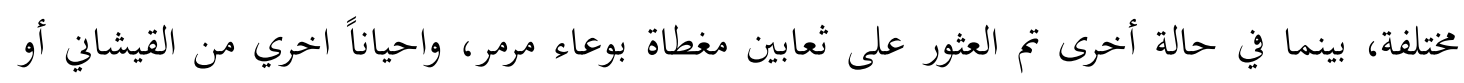
العقيق، كما احتوي احداهما على بقايا نسيج ناعم، وعادة ما تكون بيضاء.

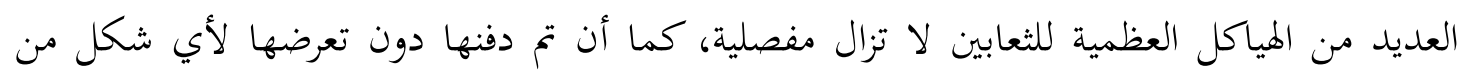
أشكال التشويه، على الرغم من أهما ربما كانت حية أو ميتة في وقت الدفن، تنتمي أوعية القرابين في قلعة البحرين إلى محموعة الفخار المعتادة في فاية فترة دلمون المتأخرة. يبدو أن الثعابين وُضعت لأول مرة، ربما على قيد الحياة، في أكياس من القماش، منها ايضاً عثر بداخلها الخرز القيشاني أو العقيق، في حالات نادرة لؤلؤة (10) كما عثر أيضاً على تسعة وعشرين آنية، تميزت هذه الاواني بأها مدفونة في أرضية من الجبس أو من الحجر الجيري المكسو ونظراً لقرب عدد من هذه الاواني التي بداخلها الثعابين، فإن الدكتور "غلوب" استنتج أن كان هناك مكان لذذه الثعابين استخدم بشكل ثانوي كمذبح، وحوله

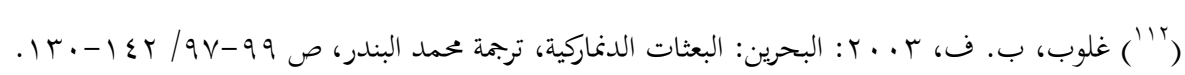
$\left({ }^{113}\right)$ Waleed, M., Al-Sadeqi, 2013: THE ANCIENT BEADS OF BAHRAIN: A Study of Ornaments from the Dilmun and Tylos Eras, Volume I، Durham University Submitted for the degree of PhD in Archaeology Department of Archaeology, Durham University, p. 307.

$\left({ }^{115}\right)$ Lombard, 2018: 62.

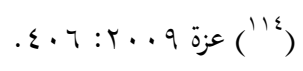


تم تقديم القرابين وأيضاً تم وضعها. من هذه التكهنات، أي انه أشار إلى أن الثعابين المدفونة حول هذا

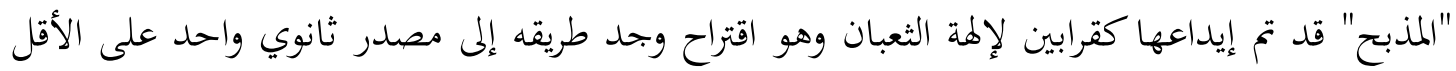

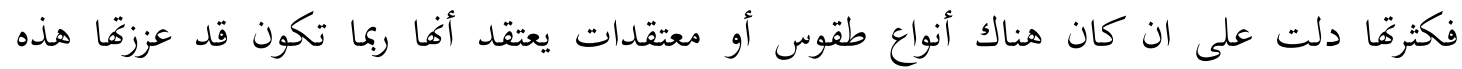

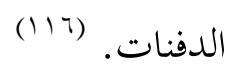

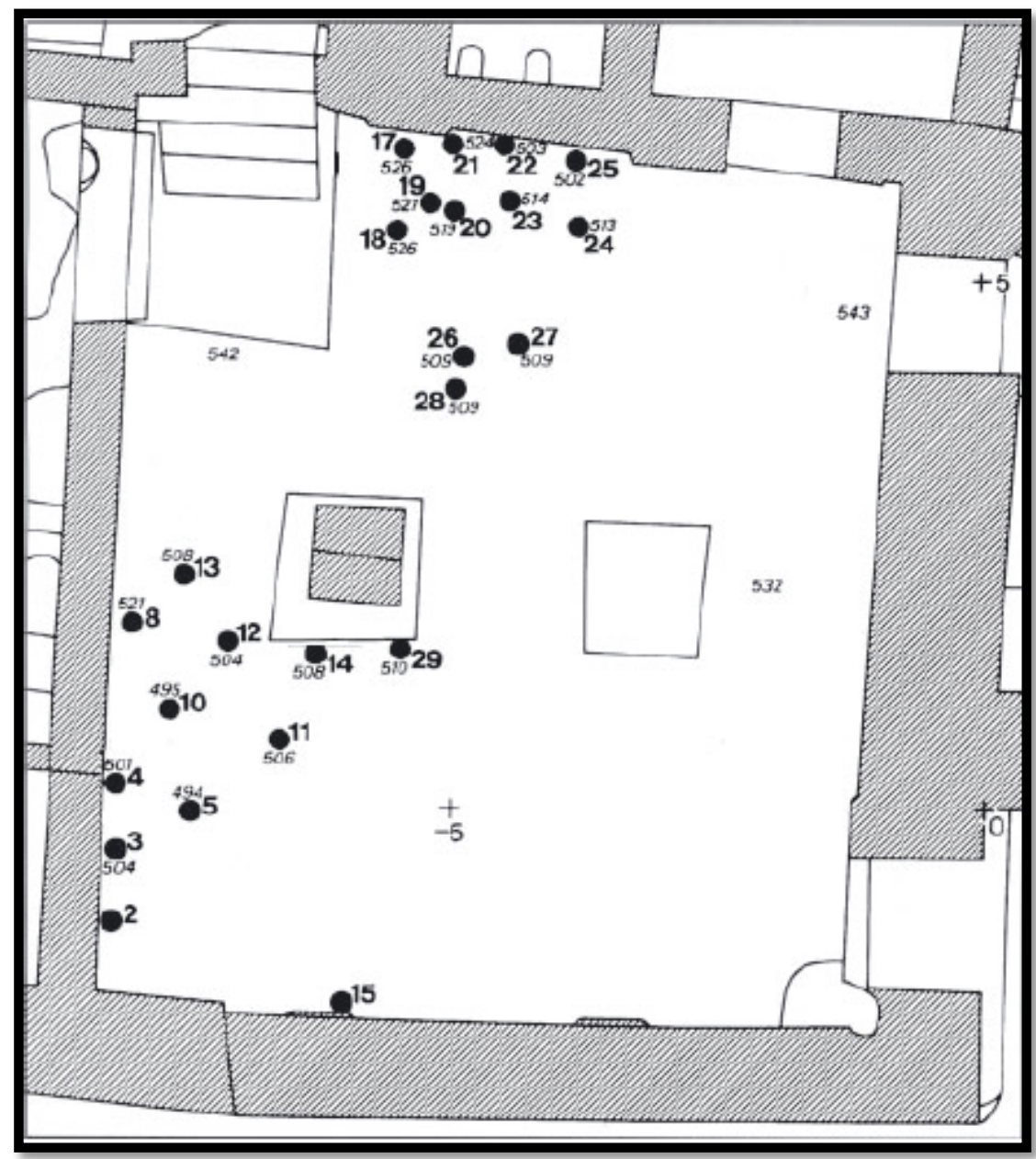

(الشكل رقم ب Y ) توزيع الثعابين داخل احدى قاعات قلعة البحرين

Potts 2007: 55-74. Fig. 2-3, p.58

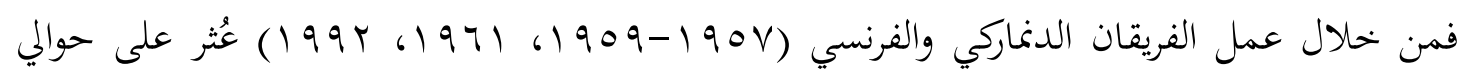

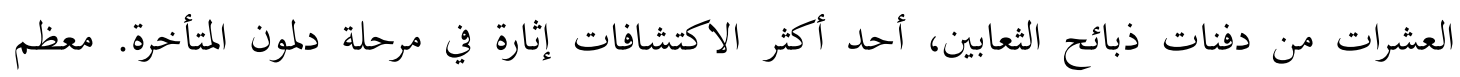

${ }^{116}$ ) Glob, P., V., 1958: Slangeofre I Bahrains Oldtidshovedstad (Snake sacrifices in Bahrain's ancient capital). KUML 1957, p.125. 
الاوعية من الفخار والمرمر على أعماق مختلفة في ثقوب محفورة في الأرضيات المغطاة بالعديد من الغرف المتعلقة بالمرحلة المتأخرة من المبنى، وأغطية الأواني من الفخار أو الخشب أو أو الحجر. (llv) ذبائح الثعابين في دلمون ترجع إلى فترات قديمة متعددة، فقد عاصرت تلك الذبائح الى الفترة الأخمينية وهناك من رأي اهما ترجع إلى فترات أخري قريبة من هذه الفترة، فحتى لو كانت بعض المقارنات قد تعود قليلاً قبل أو بعد العصر الأخميني فالنقطة الأساسية هي أن الاواني ترجع إلى تلك فالفترة تقريباً. فهناك من اعتقد ان تضحيات الثعابين تعود إلى الألفية الثانية قبل الميلاد، وأها كانت إهداء لمعبودة، وهو اقتراح لا يمكن إلا أن يكون الدافع وراءه مقارنات مع الآخرين وليس بأي دليل من الحفريات نفسها، وإلا أن كان هناك إجابة على السؤال الذي يطرح نفسه وهو ما إلهة الثعبان التي كانت تُعبد هنا في هذه الفترة؟ لا يمكن تحديدها بعد، ولكن ليس هناك شك في أن مثل هذه الإلهة للخصوبة كانت تُعبد في الواقع في مناطق كبيرة في هذه الفترة فقط، ففي جزيرة كريت، على سبيل المثال، عُرفت إلهة ثعبان معاصرة للاكتشافات من القلعة، وفي تاريخ لاحق إلى حد ما في الدنمارك في أواخر العصر البرونزي. كلاهما من المحتمل أن يكون لمما أصل مشترك في الشرق، ففي عدد من المعتقدات، يظهر الثعبان لاحقًا على أنه روح الموتى، وهو معروف على هذا النحو بين الإغريق والرومان (^l() وبجنوب شبه الجزيرة العربية، فإن ارتباط الثعبان واسم الإله واد إلالة الرئيسي في مملكة معين كما كان يعتقد ان كان لها وظيفة لحماية القبور بالإضافة إلى أن تم تفسير الثعابين في جنوب الجزيرة العربية في بعض الأحيان على إلى أها عروض نذرية وربما تم نقل هذه الفكرة إلى شرق الجزيرة العربية، ومع كل ذلك حتى الان لا توجد أدلة

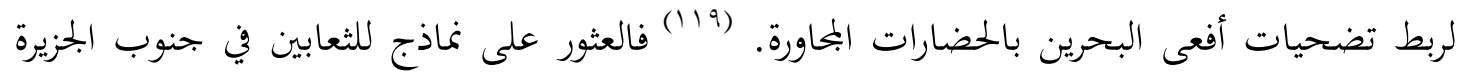
العربية وجنوب شرق شبه الجزيرة العربية ليس لمما صلة واضحة بالثعابين المدفونة في البحرين، ولم يتم

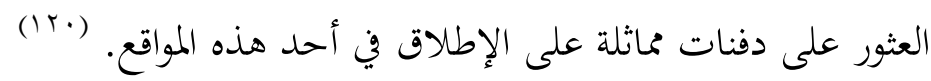
الأوعية التي كانت تحفظ الثعابين والتي عثر عليها داخل قلعة البحرين أوعية مختلفة الأحجام والأشكال، فجميع الأوعية المستخدمة لحمل ذبائح الثعابين مفتوحة. منها الضحلة والعميقة ومنها أيضا أوعية مزودة بأغطية ويبدو أن جميع أنواع الأوعية صنعت محليًا ويتضح ذلك من توصيف الأواني نظرًا لوجود هالات بيضاء، وأسطح صفراء أو صفراء مخضرة جنبًا إلى جنب مع الأواني الحمراء أو الوردية، وهو الأمر الشائع في جميع أنحاء بحموعة الخزف في دلمون. (الشكل رقم TV)

$\left({ }^{117}\right)$ Lombard 2018: 62 .

$\left({ }^{118}\right)$ Potts 2007: 64.

(119) Maraqten, M., 1998: Curse formulae in South Arabian inscriptions and some of their Semitic parallels. PSAS 28: p 193.

$\left({ }^{120}\right)$ Potts 2007: 69. 


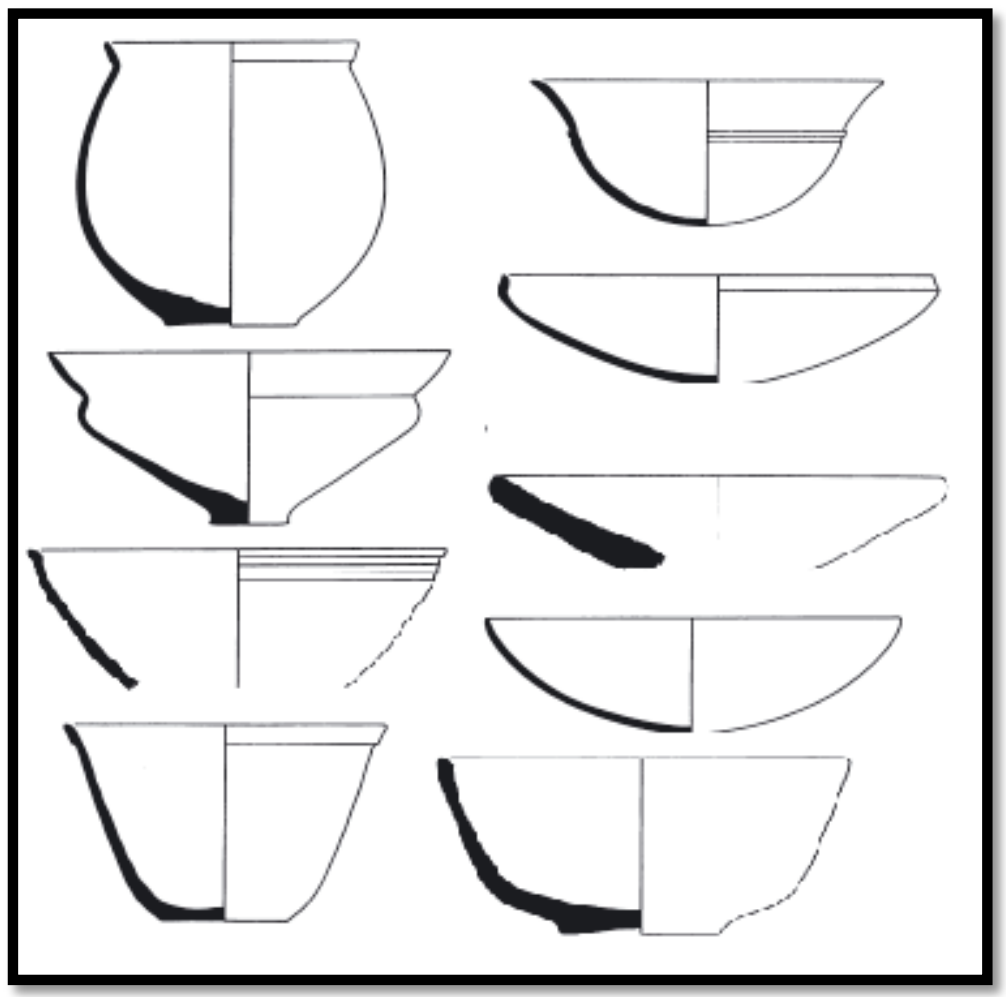

(الشكل رقم TV) بعض اشكال الاوعية التي تم العثور بداخلها على الثعابين

Potts2007: 55-74.pig. 6, p.60

تم التعرف على نوعين فقط من الثعابين الموجودة في الدفنات وهي ثعبان الفئران وتعبان البحر (الشكل

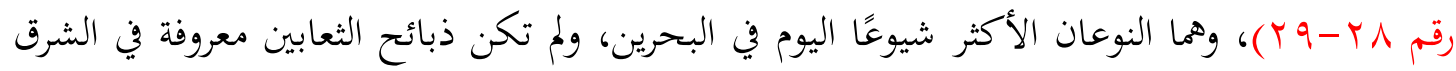

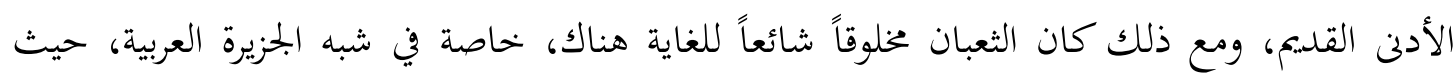
يرتبط بفكرة الخصوبة. يمكن أن يكون هذا الدليل الفريد نتيجة ممارسات منزلية تمدف إلى توفير الحماية الإلهية والخصوبة والعمر المديد للسكان. (IT) تعددت الآراء حول دفنات الثعبان في دلمون، حيث ربط الدكتور "جيفري بيبي" تضحيات الثعابين مع الثعبان وعناصر اللؤلؤ المحتملة في ملحمة جلجامش، مما يشير إلى أن دفن الثعابين كان إجراءً وقائيًا ضد المرض والموت. فكان هناك دفنات تحتوي على لآلئ ودفنات تحتوي على الخرز الذي يمثل بدائل اللآلئ التي قدمها الفقراء كما قدم الدكتور "دانيال بوتس" تفسيرً آخر محتملاً لأضاحي الثعابين مؤخراً، ويشير إلى أنه ربما كان هناك تأثير هندي يكمن وراء هذه الممارسة، بسبب هذا التأثير يتجه غربًا خلال الفترة الأخينية (ITY)

$\left({ }^{121}\right)$ Lombard 2018: 62.

${ }^{122}$ ) Waleed 2013: 146. 
ومن ناحية اخري، فإن الدكتور "غلوب" اقترح أن هذه الدفنات تم إيداعها كقرابين لإلهة الثعبان في تلك المنطقة (rri) وهناك من اقترح أن تضحيات الثعابين قد تكون مرتبطة بإله بلاد النهرين ذو الأصول السومرية وعبادة المعبد التي ظلت واضحة على الأقل حتى عصر أور الثالث (111 إY-7 . . ق ق.م)، والذي استمرت عبادته إلى أوقات لاحقة كإله شعبي للعالم السفلي، والخصوبة، والشفاء، والسحر،

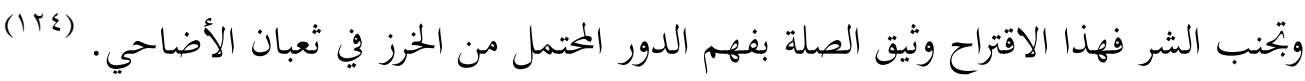

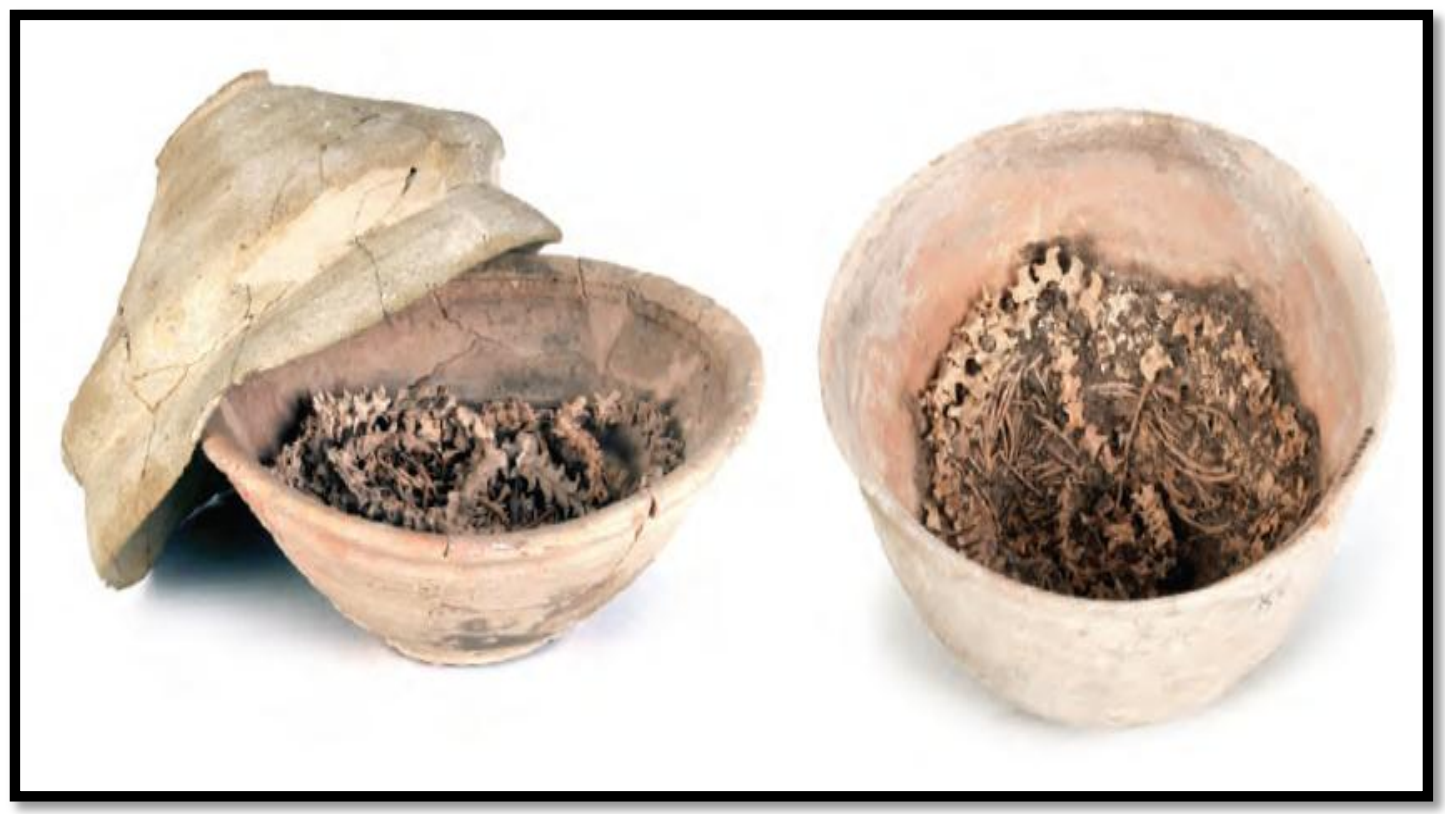

(الشكل رقم Y^) الأضحية "وعاء الأفعى" يمكن رؤية الهيكل العظمي الملفوف للثعبان، بالإضافة إلى خرزة صغيرة من القيشاني الأخضر. الالف الأول قبل الميلاد

Lombard 2018: 62

لم يقتصر وجود الثعبان في دلمون على الدفنات أو الأضاحي التي عثر عليها داخل الأواني بل عثر على بعض اللقى الأثرية التي تثبت وجود الثعبان في حياة سكان المنطقة فقد عثر على حلقة أصبع ملفوفة

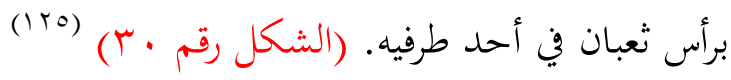

$\left.{ }^{123}\right)$ Glob 1958: 125.

$\left({ }^{124}\right)$ Waleed 2013: 146-147.

$\left({ }^{125}\right)$ Lombard 2018: 75. 


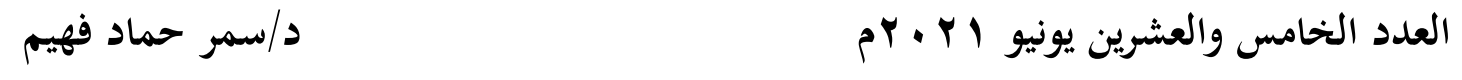

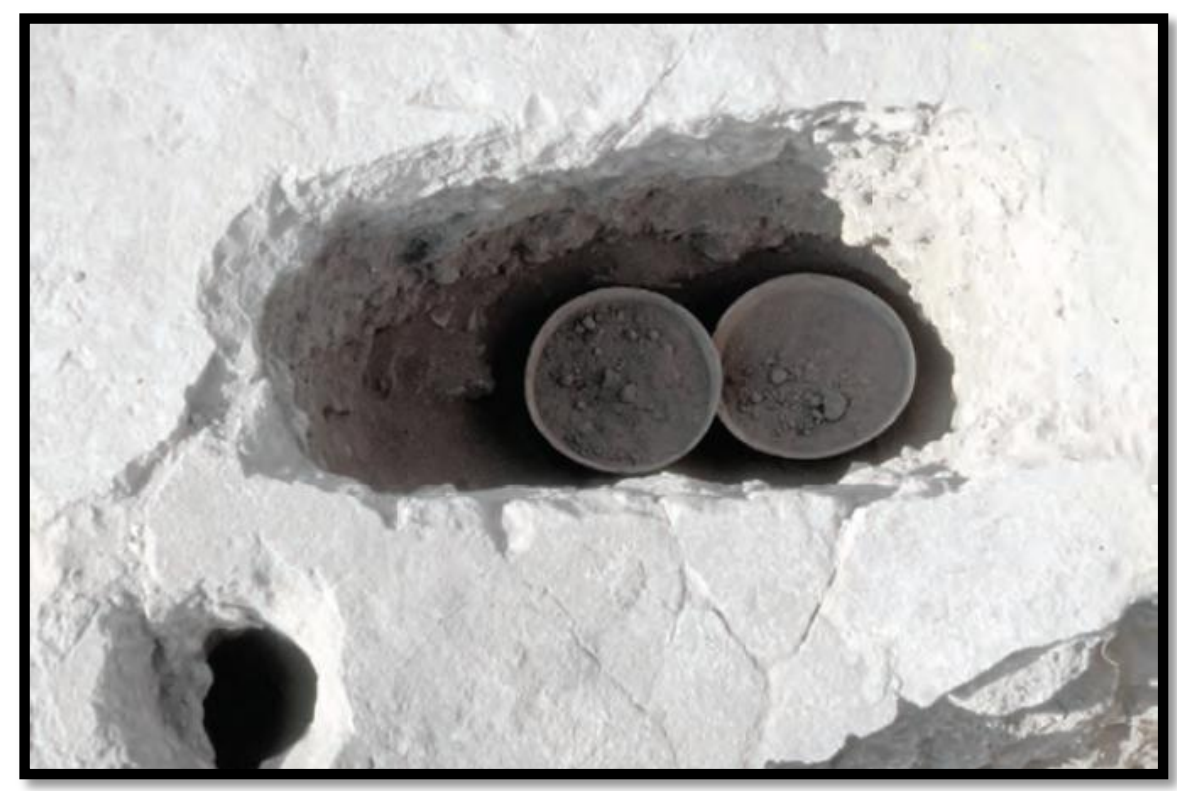

(الشكل رقم 9 (Y) أرضية غرفة مغطاة بالجبس، بها ثقوب مثقوبة بها أوعية الأفعى، البعثة الأثرية

الفرنسية، منطقة التنقيب المركزية (199 1 (1).

Lombard 2018: 63

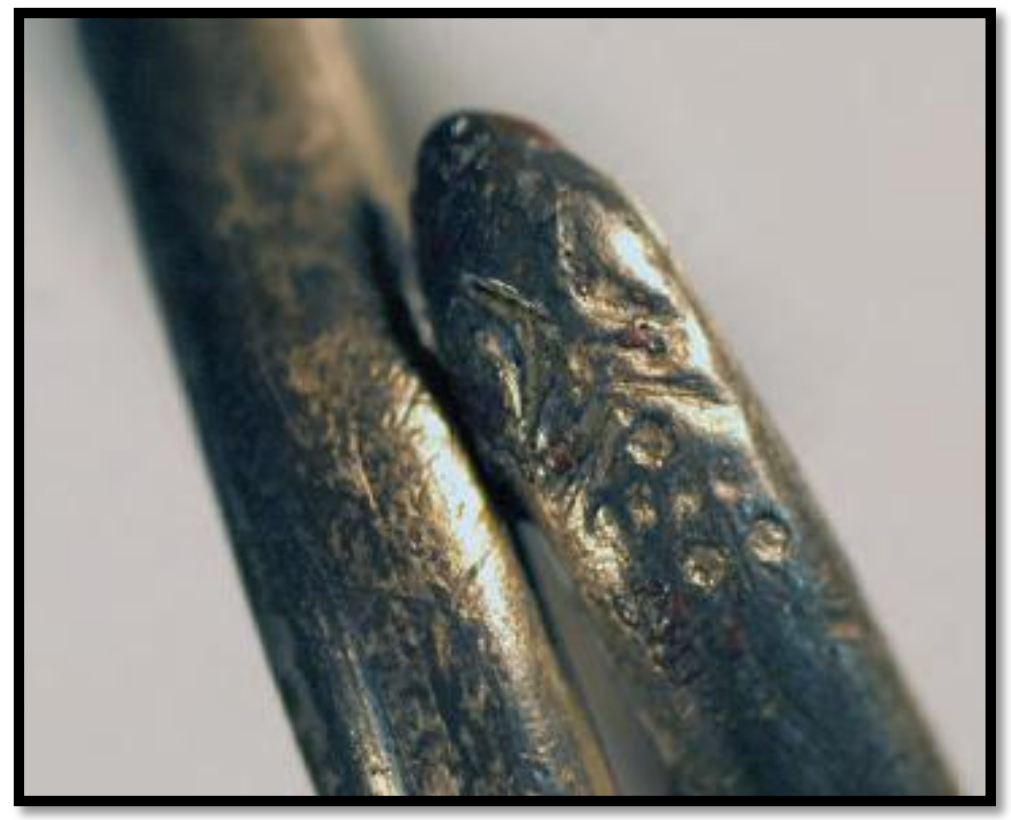

(الشكل رقم • ץ) نظرة قريبة من حلقة إصبع ملفوفة برأس ثعبان في أحد طرفيه

Lombard 2018: 75 
مقارنة بين تماثيل الثعبان في مصر القديمة وشرق شبة الجزيرة العربية: أولاً-في مصر القديمة: - - بلا شك وصل الثعبان في مصر القديمة الى مرحلة التقديس والعبادة وهذا ما ذكره بعض النصوص المصرية القديمة، فتماثيل الثعبان ربما كانت نذرية أو أدوات للحماية لدرء الكوابيس، أو اتقاء الآلهة، أو كمكونات للتعاويذ. - متاثيل الثعابين كانت تصنع من الطين المحروق أو الغير محروق كما ان تم صناعتها أيضاً من الفخار المزجج أي من مادة خزفية مزججة غير طينية، هذا بالإضافة الى صناعتها من الزجاج، ويبدو أن بعض من هذه التماثيل تفتقر الي الزينة، فقد كان من هذه التماثيل ما هو قائم بذاته ومنها من كانت تستخدم كجزء من الأوعية، وجميع التماثيل صناعة محليه. - بدأ ظهور تماثيل الثعابين بشكل واضح خلال الدولة الحديثة، حيث انتشرت تماثيل الثعابين في العديد من الفئات الإجتماعية، مثل الجنود والحرفيين والنساء والأطفال، وربما لعبت دورًا في نقل الممارسات الدينية وتطويرها، ولم يكن هناك معابد لعبادة الثعبان في مصر القديمة بالرغم من أهميتها واتخاذها إلهه إلا ان لم يكن لها معابد بكثرة في مصر القديمة.

ثانيا-في شرق شبة الجزيرة العربية:

- ـ ربما وصل الثعبان الى العبادة والتقديس في منطقة شرق شبة الجزيرة العربية ولكن لم يكن هناك نصوص تؤكد ذلك ولكن وجود الثعبان وتماثيله بكثرة منفردة أو على الأواني يؤكد عبادة او

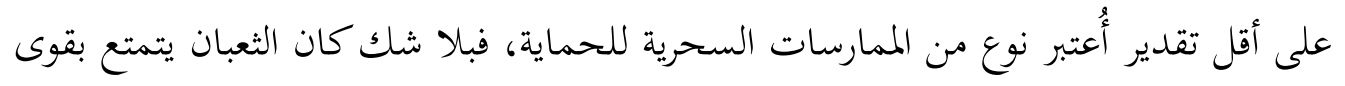
سحرية على أفراد البمتمع، ومن المختمل أنه كانت تقام طقوس لها في معابد مخصصة. - متماثيل الثعابين صنعت في شرق شبة الجزيرة العربية من الطين المحروق كما ان تم صناعتها من الفخار المزجج وكانت تماثيل الثعابين تحمل القليل من الزينة وبالأخص قشور الثعابين، فقد كان من هذه التماثيل ما هو قائم بذاته ومنها من كانت تستخدم كجزء من الأوعية أو الأغطية أو حتى بعض الخناجر، كما تم صناعة تماثيل الثعبان أيضا من البرونز، وكانت جميع تلك التماثيل صناعة محلية من داخل منطقة شرق شبة الجزيرة العربية - بدأ ظهور تماثيل الثعابين بشكل واضح خلال العصر الحديدي، حيث انتشرت تماثيل الثعابين في العديد من الأماكن، وربما لعبت دورًا في نقل الممارسات الدينية، ومن المحتمل ان كان هناك العديد من المعابد التي يتم فيها عبادة الثعبان كما في القصيص والبثنة، فربما إحدى هذه 
الشعائر تقديم التماثيل البرونزيه، والأواني التي تحمل زخارفها، كهدايا نذرية للإله، أو توضع كمرفقات جنائزية في المدافن مع المتوفين. - مما سبق يمكن استخلاص ما يلي: هناك العديد من السمات للثعابين في مصر القديمة، كما ارتبطت الحية بإلهات بعينها مثل واجيت ونوت ونسرت والمعبودتين حنوت وامتت، ونلاحظ ان تقديس الثعابين في مصر القديمة تم بشكل كبير ليس لشكلة وانما لقدرته الكبيرة في بعث الطاقة المتجددة. عُثر على نماذج مختلفة لتماثيل الثعابين في مصر والتي تم تقسيمها الى نماذج من الطين المحروق تم تصميمها لتكون تماثيل طينية قائمة بذاهما، أو نماذج من الطين المحروق التي تم العثور عليها ملتصقة في جانب أو قاع الأوعية ' او نماذج من الطين غير المحروق كما في منطقة أبيدوس. المخزي الرمزي للثعبان في الديانات القديمة يرجع الى دورة حياة الثعبان الطبيعية، حيث تم ربطها بعقيدة الخلود والبعث. الثعابين وارتباطها بالأساطير والمعتقدات لم تكن لها مساحه كافيه من خلال البحوث والدراسات في منطقه شرق الجزيرة العربية، فهناك معلومات قليله عن الثعبان ورمزيته في تلك المنطقة، فكان هناك وجود للثعبان في شرق الجزيرة العربية خلال العصور القديمة وهناك بعض الباحثين الذين تطرقوا إلى هذا الموضوع وتم اثبات وجود الثعبان من خلال اللُقي الأثرية التي تم

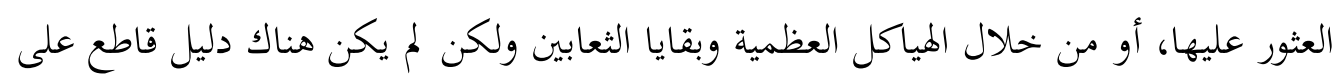
وجود عباده للثعابين في منطقه شرق الجزيرة العربية بعكس وجود هذه العبادة في مصر القديمة. تضحيات الأفاعي في بلاد النهرين تم ربطها بملحمة جلجامش، فأقترح البعض تضحيات الأفعى قدمت دليلاً واضحاً على أن أسطورة جلجامش كانت لا تزال جزءاً حياً وجزاء لا يتجزأ

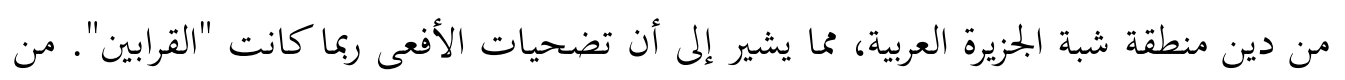
المتوسلين بحثًا عن الصحة أو العمر الطويل. تم التعرف على نوعين فقط من الثعابين الموجودة في الدفنات وهي ثعبان الفئران وثعبان البحر، وهما النوعان الأكثر شيوعًا اليوم في شرق شبة الجزيرة العربية، ولم تكن أضاحي الثعابين معروفة في الشرق الأدنى القديم، ومع ذلك كان الثعبان مخلوقاً شائعاً للغاية هناك، خاصة في شبه الجزيرة العربية، حيث يرتبط بفكرة الخصوبة. يمكن أن يكون هذا الدليل الفريد نتيجة ممارسات منزلية تمدف إلى توفير الحماية الإلهية والخحوبة والعمر المديد للسكان.

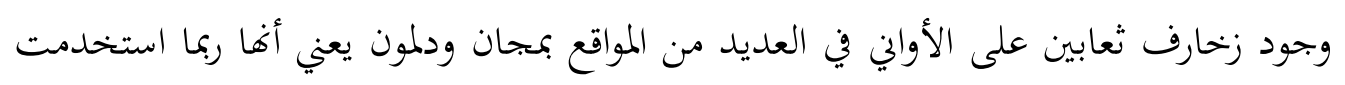
هذه الأواني في العديد من الأغراض الدينية، وقد يُفسر وجود زخرفة الثعابين على جرار التخزين 


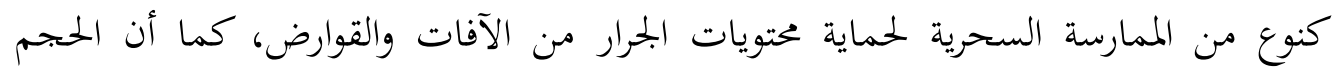

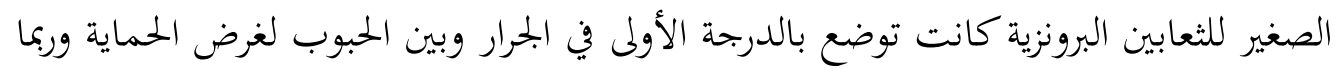
أيضاً في مخازن المحاصيل الزراعية. الدلائل الأثرية لنماذج الثعابين التي تم اكتشافها في منطقه شرق الجزيرة العربية ليست فقط من الناصن

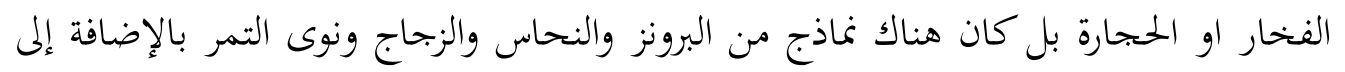

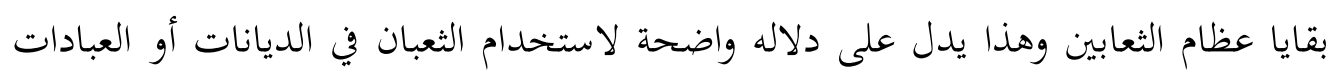

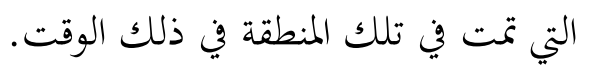
الثعابين المكتشفة تشكل أنواع عديدة من الثعابين منها الكوبرا والفيبر والثعابين العادية التي لعني

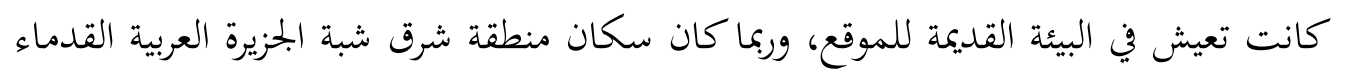

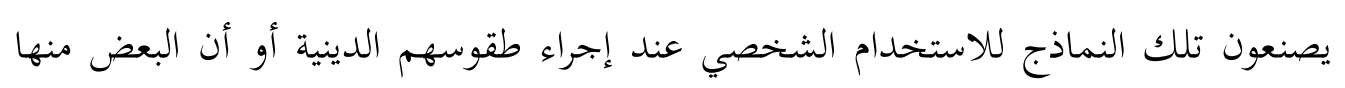
كان يصدر لحضارات أخرى.

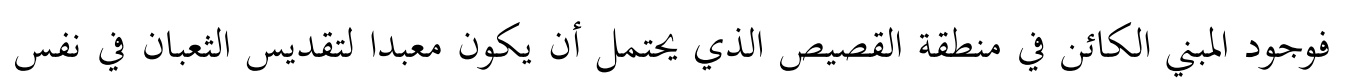

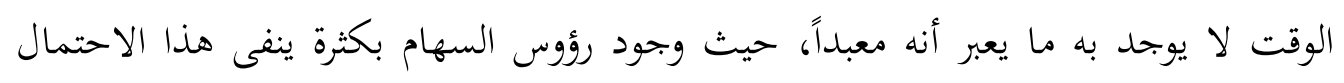

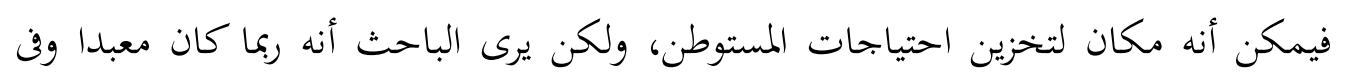

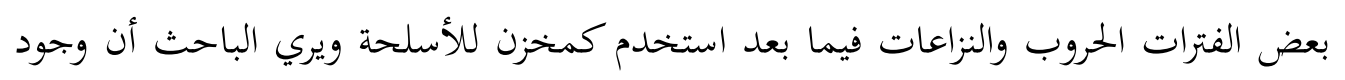

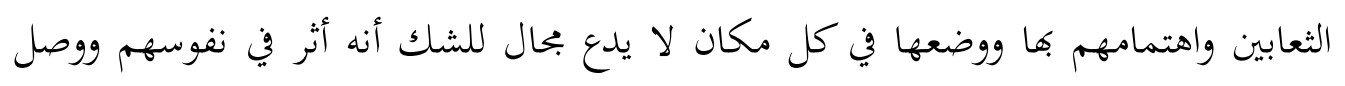

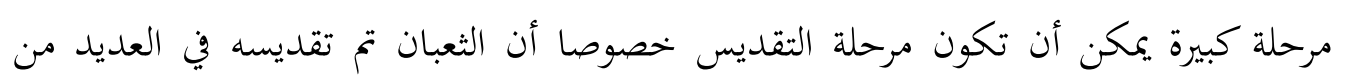
الحضارات السابقة والمحاورة.

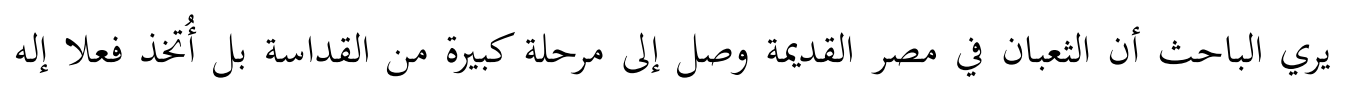

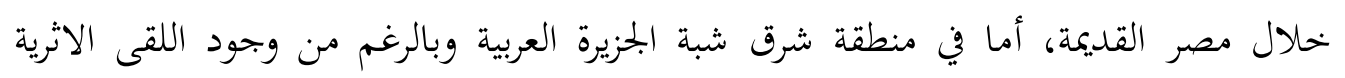

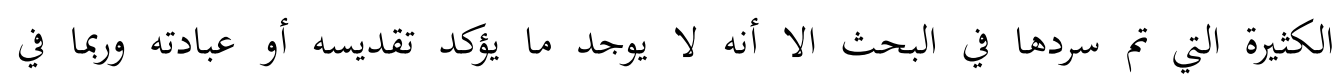

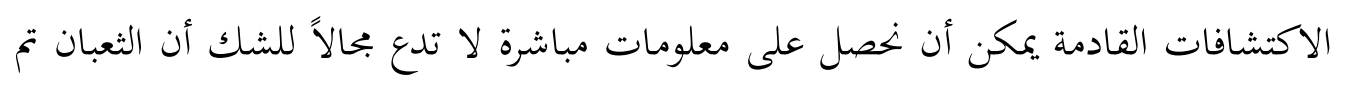

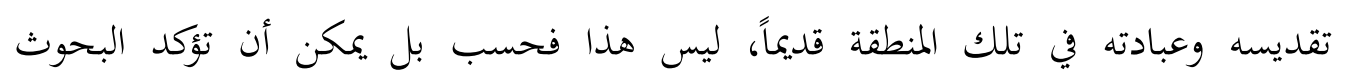

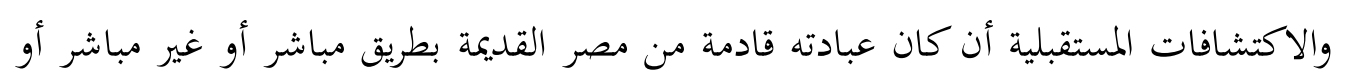
من مناطق حضارية أخري. المراجع العربية: الآداب، جامعة طنطا. 
r- ثناء أنس الوجود، \&191) رمز الأفعى في التراث العربي، كلية الآداب، جامعة عين شمس، رسالة ماجستير منشورة، مكتبة الشباب.

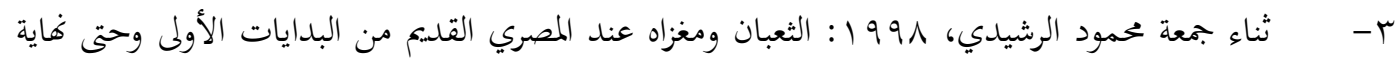

الدولة الحديثة، رسالة دكتوراه غير منشورة، كلية الآثار، جامعة القاهرة.

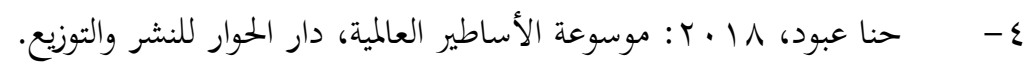

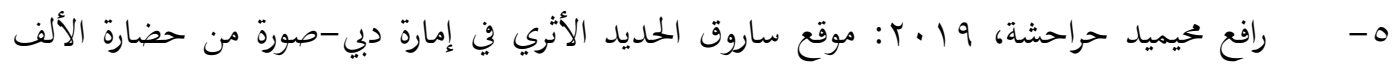

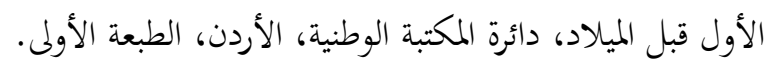

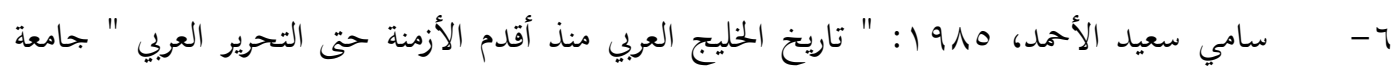
البصرة.

سمير عزت عبد العزيز بدر، 17 • ب: العصر الحديدي بدولة الامارات العربية المتحدة دراسة اثرية $-v$ حضارية، رسالة ماجستير غير منشورة، جامعة كفر الشيخ، كلية الآداب.

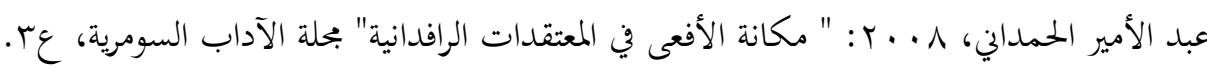

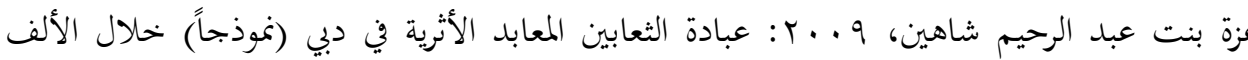

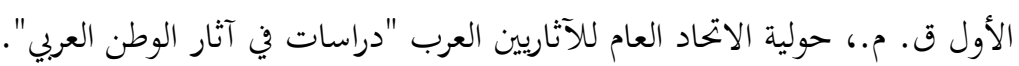

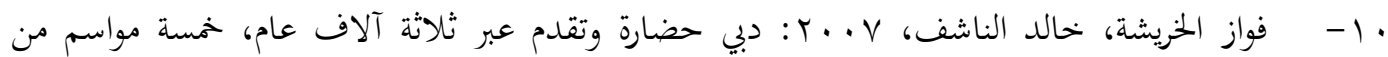

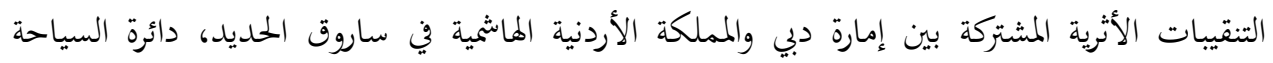

$$
\text { والتسويق التجاري دبي. }
$$

مروة محمود محمد محمد، ب ا · ب: الحيوانات الخرافية في مصر والشرق الأدنى القديم (مر -العراق-إيران) منذ دهور ما قبل التاريخ وحتى فاية الدولة الحديثة دراسة فنية مقارنة، رسالة ماجستير غير منشورة، كلية

$$
\text { الآداب - مامعة أسيوط. }
$$

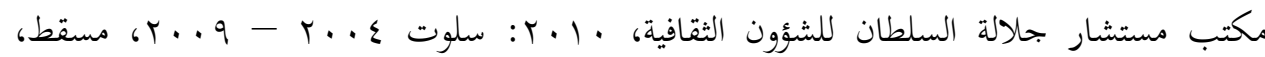

سلطنة عمان.

مني الشايب، 999 1: الرموز المقدسة في أدوات التزين في مصر القديمة حتى غاية عصر الدولة الحديثة،

$$
\text { رسالة ماجستير غير منشورة، القاهرة. }
$$

منير يوسف طه، 1919 1: " اكتشاف العصر الحديدي في دوله الإمارات العربية المتحدة"، مركز

$$
\text { دراسات الخليج العربي، جامعة البصرة. }
$$

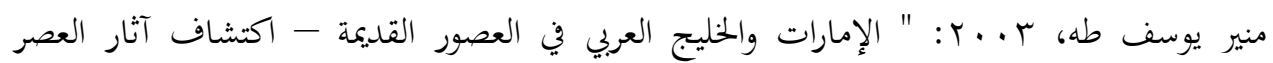

الحديدي " مركز زايد للتراث والتاريخ.

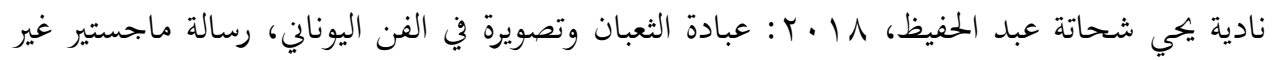




$$
\begin{aligned}
& \text { IV - اصر سعيد الجهوري، ـ I إr: رمزيه الثعبان في عصور ما قبل التاريخ وفترات ما قبيل الاسلام في شبه } \\
& \text { الجزيرة العمانية: واقع الدليل الاثري، البحلة العربية للعلوم الإنسانية، جامعه الكويت، بحلس النشر }
\end{aligned}
$$

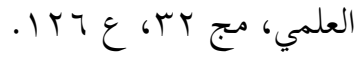

$$
\begin{aligned}
& \text { 11 - وليم نظير، } 1971 \text { 1 : الثروة النباتية عند قدماء المصريين - القاهرة. }
\end{aligned}
$$

المراجع المعربة: المنعم أبو بكر ومحمد أنور شكري، القاهرة

r- - بوركارت فوكت، 1910: " تقرير أولى عن التنقيبات الأثرية في مدفن A من عصر أم النار - منطقة

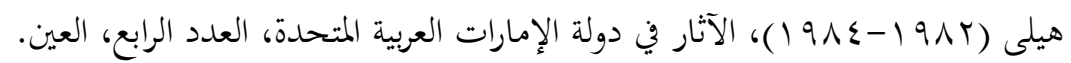

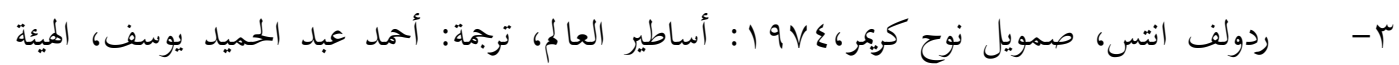
المصرية العامة للكتاب، القاهرة.

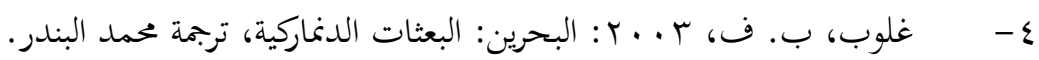

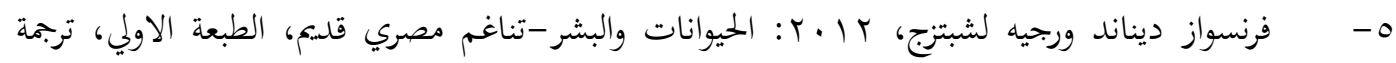
فاطمة عبد الله محمود، مراجعة وتقديم: محمود ماهر طه، المركز القومي للترجمة، القاهرة.

\section{المراجع الأجنبية:}

1- Avanzini, A., \& Phillips, C., 2010: An Outline of Recent Discoveries at Salut in the Sultanate of Oman. Eastern Arabia, in the First Millennium BC. Arabia Antica 6. Edited by Alessandra Avanzini. Roma.

2- Benoist , A., 2005: " fifth archaeological campaign at Bithna " Preliminary Report, Fujairah, French Mission In U.A.E.

3- Benoist, A., 2010: Authority and Religion in South East Arabia during the Iron Age: A Review of Architecture and Material from Columned Halls and Cultic Sites ،Eastern Arabia in the First Millennium BC. Arabia Antica 6. Edited by Alessandra Avanzini, Roma.

4- Benoist, Anne, 2008: "The Iron Age Culture in the United Arab Emirates, between 1100B.C and 250B.C "Bulletin of Archaeology, Kanazawa Univ. 29.

5- Bibby, T., G., 1969: Looking for Dilmun. New York: Alfred Knopf.

6- Blackman, A., M., 1932: Middle-Egyptian Stories -- Part I. Fondation Égyptologique Reine Élisabeth, Brussels.

7- De Buck, C., T., 1948: VII, 304 (sp. 1052).

8- Franck Goddio \& Manfred Clauss, eds., 2006: Egypt's Sunken Treasures, photographs by Christoph Gerigk (London: Prestel). 
9- Frifelt, Karen, 1975: “ A Possible Link Between the Jemdet Nasr and the Umm An-Nar Graves of Oman “ J.O.S.

10-Frothingham, A., L., 1916: "Babylonian Origin of Hermes the Snake-God, and of the Caduceus1",AJA 20,No.2.

11-Gimbutas, 1989: The Language of the Goddess, San Francisco.

12-Glob, P., V., 1958: Slangeofre I Bahrains Oldtidshovedstad (Snake sacrifices in Bahrain's ancient capital). KUML 1957.

13-Hansman, J., 1976: "Gilgamesh,Humbaba and the Land of the Erin-Trees", Iraq 38,No.1.

14-Horning, E., 1963: Das Amduat, Die Schrift des Verborgenen Raumes, Wiesbaden.

15-Hussein Abdel- Aziz, 1996: The Anthropomorphic Anguipede deities in Graeco - Roman Egypt.

16-Kasia Szpakowska, 2012: Striking Cobra Spitting Fire, Archive Für Religionsgeschichte, 14.

17-Kasia Szpakowska, 2015: Snake cult and Egyptian military bases, Koninklijke Brill NV, Leiden, Boston.

18-Latifa Tazzit,: La Vita Quotidiana Nell'Antico Egitto, Collaborazione Museo Egizio -Mondi In Citta Onlus, Feste, Musica, Sport e Divertimento.

19-Lombard, P., 1989: “The Late Dilmun period (1000 - 400 B.C. ) "BNM, Vol. 1.

20-Lombard, P., 2018: Qal'at al-Bahrain, Ancient Capital and Harbour of Dilmun. The Site Museum, a world heritage site, Bahrain Authority for Culture and Antiquities.

21-Maraqten, M., 1998: Curse formulae in South Arabian inscriptions and some of their Semitic parallels. PSAS 28.

22-Mertens, 1960: The World of Amphibians and Reptiles, (Trans. By Parker), London, p. 28.

23-Mouton, M., Benoist, A., Cordoba, J., 2011:"The Snake Figuration in Iron Age" Journal of the National Center for Documentation \& Research, LIWA, VOL. 3, UAE.

24-Mysliwiec, k., 1979: Studien Zum Got Atum, in HÄb 8, Hildesheim.

25-Okuda, J., \& Kiyokawa, R., 2000: "Snake as a symbol in medicine and pharmacy- a historical study", yakushigaku zasshi: the journal of Japanese history of pharmacy, Japanese society of history of pharmacy, Japan, 35.1.

26-Parpola, S., 2007: Assyrian- English -Assyrian Dictionary, University of Helsinki. 
27-Peet, T., E., and Woolley, C., L., 1923: The city of Akhenaten I, London, Egypt exploration society.

28-Piankoff, A., 1956: The Theology of the new kingdom, Le Caire.

29-Piccione, A., P., 1990: Mehen, Mysteries and Resurrection from the copied serpent, JARCE, 27.

30-Potts, D., T., 1991: "Further Excavations At Tell Abraq “ The 1990 Season, Copenhagen, Munskgeerd.

31-Potts, D., T., 2004: The numinious and the immanent: Some thoughts on Kurangun and the Rudkhaneh-e Fahliyan. In: von Folsach K Thrane H \& Thuesen T, eds. From handaxe to khan: Essays presented to Peder Mortensen on the occasion of his 70th birthday. Aarhus: Aarhus University Press.

32-Potts, D., T., 2007: Revisiting the snake burials of the Late Dilmun building complex on Bahrain, Arabian Archaeology and Epigraphy.

33-Potts, D., T., 2012: Peter Hellyer "Fifty Years of Emirates Archaeology "Published by Motivate Publishing.

34-Raven, M., J., 2012: Egyptian magic: the quest for Thoth's book of secrets, Cairo, American university of Cairo.

35-Saied Götterglaube Und Göttheiten in Der Vorgeschichte Und Frühzeit Ägyptens.

36-Salut, Sultanate of Oman, report (2009-2005).

37-Schafer, 1974: Principles of Egyptian Art, (Trans. by J. Baines), Oxford.

38-Smith, 1981: The Art and Architecture of Ancient Egyptian, New York.

39-Stevens, A., k., 2006: Private religion at Amarna: the material evidence, bar international series 1587, Oxford, Archaeopress.

40-Sweeney, D., 2009: gender and oracular practice in Deir El-Medina, Zeitschrift für Ägyptische sprache und altertumskunde 135/2.

41-Taha, M., Y., 2009: “ The Discovery Of The Iron Age In The United Arab Emirates " First Edition, Ministry Of Culture ,Youth And Community Development,U.A.E.

42-Taha, M.,Y., 1983: The Archaeology of the Arabian Gulf during the first Millennium B.C. Al Rafidan III-IV.

43-Waleed, M., Al-Sadeqi, 2013: THE ANCIENT BEADS OF BAHRAIN: A Study of Ornaments from the Dilmun and Tylos Eras, Volume I , Durham University Submitted for the degree of $\mathrm{PhD}$ in Archaeology Department of Archaeology, Durham University.

44- Wilson, L., S., \& Nachash, and Asherah, 1999: Serpent Symbolism and Death ,Life , and Healing In The Ancient Near East ,Ph.D., Yale University. 
https://www.albayan.ae

$$
\begin{aligned}
& \text { المواقع الالكترونية } \\
& \text { الموقع الرسمي لجريدة البيان الاماراتية }
\end{aligned}
$$

$$
\text { الموقع الالكتروني الرسمي لمتحف الميتروبوليتان }
$$

https://www.metmuseum.org

$$
\text { الموقع الالكتروني الرسمي لمكتبة الإسكندرية }
$$

http://antiquities.bibalex.org

$$
\text { الموقع الرسمي الالكتروني لمتحف ساروق الحديد }
$$

https://www.facebook.com 